

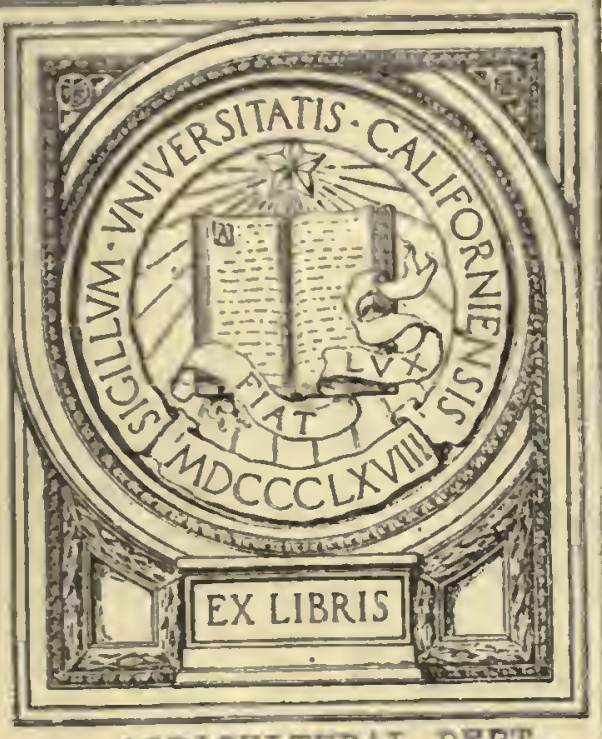

AGRICULTUPAI DRPT.

\section{THE NOVELTY}

\section{FARM ACCOUNT BOOK}

TABLE OF CONTENTS

Pages 1 to 72 - - Ledger

" 73 to 120 - - Cash Book

" 121 to 144 - - Crop Cost

" 145 to 148 - - Time Book

" 149 - - Breeding Table

“ 150 to 157 - - Milk Account

" 158 and 159 - - Inventory

" 160 to 164 - - Memorandum

Balance - - . - - Notes and Receipts

PUBLISHED BY

THE NOVELTY SUPPLY CO., HOLYOKE, MASS.

\section{SPECIAL OFFER}

Good Until August 1st, 1914

A copy of this book will be mailed to any address in the United States upon receipt of $\$ 1.00$.

The Novrlty Supply Co., 


\section{THE NOVELTY}

FARM ACCOUNT BOOK

\section{SIMPLE, CONCISE \\ AND PRACTICAL}

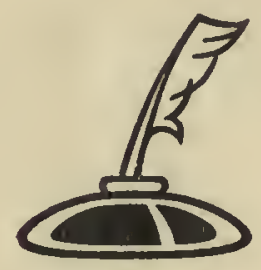

PUBLISHED BY

THE NOVELTY SUPPLY CO.,

HOLYOKE, MASS. 



\section{LEDGER ACCOUNT}

NAME

Enter below goods sold by you, cash paid by you, work done by you or your men or teams, eny article of value for which you are to be paid, notes given by you
ADDRESS

Enter bclow cash paid to you, goods delivered to you, work done for you, any article of value for which you must pay, notes given to you

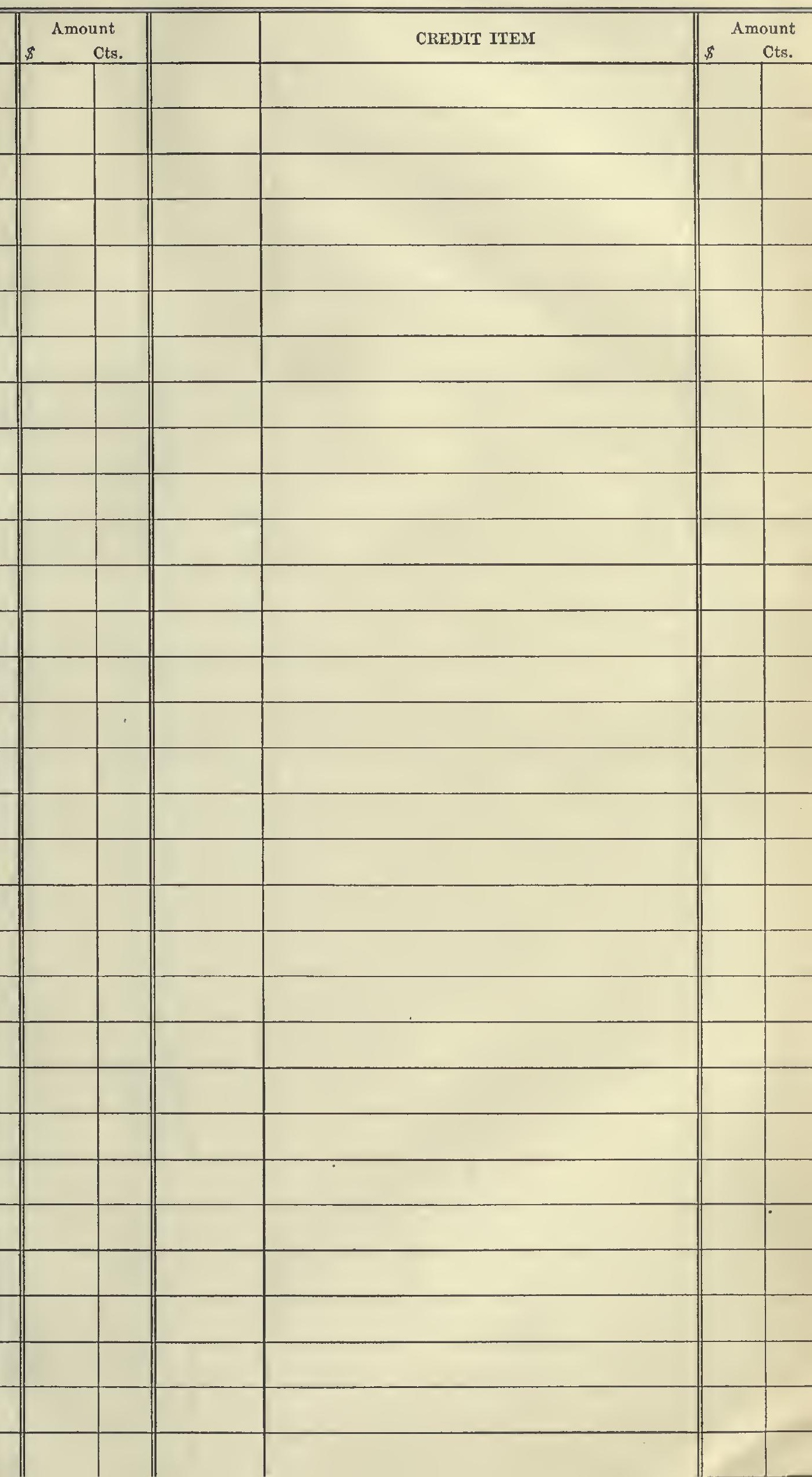


NAME

Enter below goods sold by you, cash paid by you, work done by you or your men or teams, any article of value for which you are to be paid, notes given by you

\begin{tabular}{|rr} 
Amount \\
Cts.
\end{tabular}

ADDRESS

Enter below cash paid to you, goods delivered to you, work done for you, any article of value for which you must pay, notes given to you

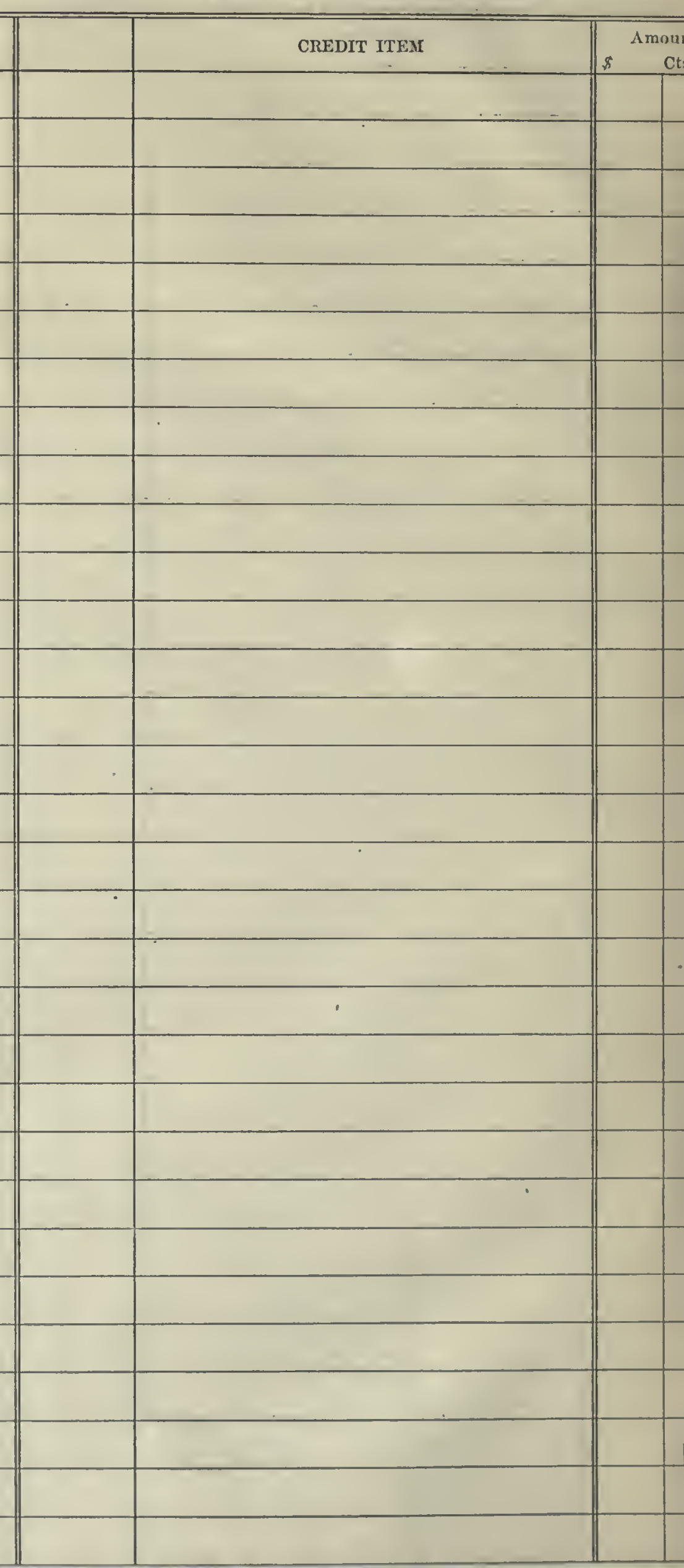


NAME

Enter below goods sold by you, csah paid by you, work done by you or your men or teamis, any article of value for which you are to be paid, notes given by you
ADDRESS

Enter below cash paid to you, goods delivered to you, work done for you, any article of value for which you must pay, notes given to you

\section{Date}

DEBIT ITEMT

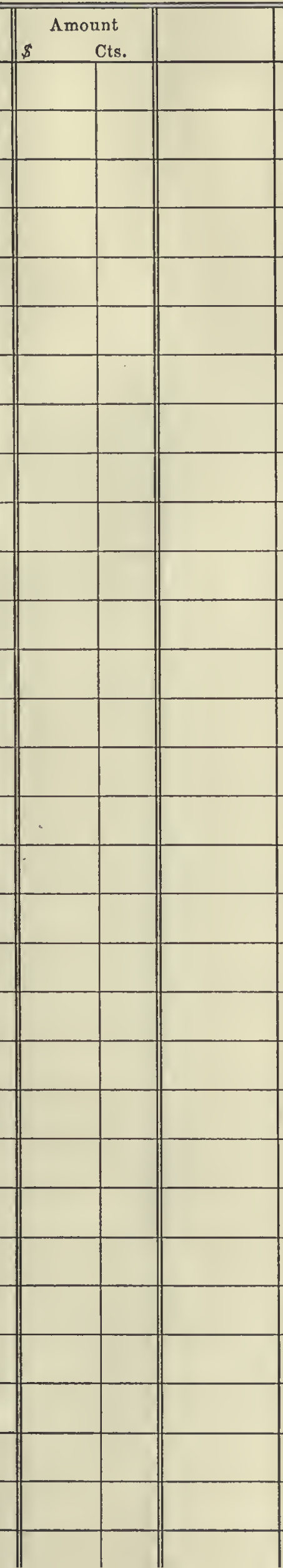

CREDIT ITEM

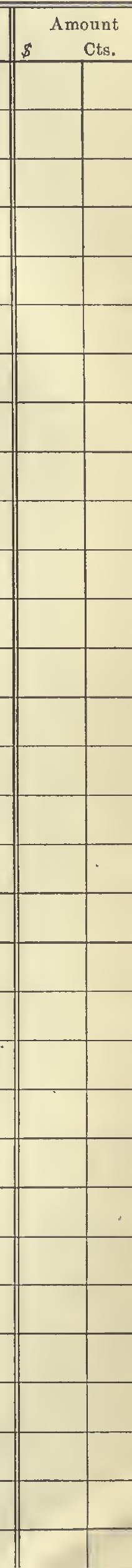


NAME

Enter below goods sold by you, cash paid by you, work done by you or your men or teams, any article of value for which you are to be'paid, notes given by you

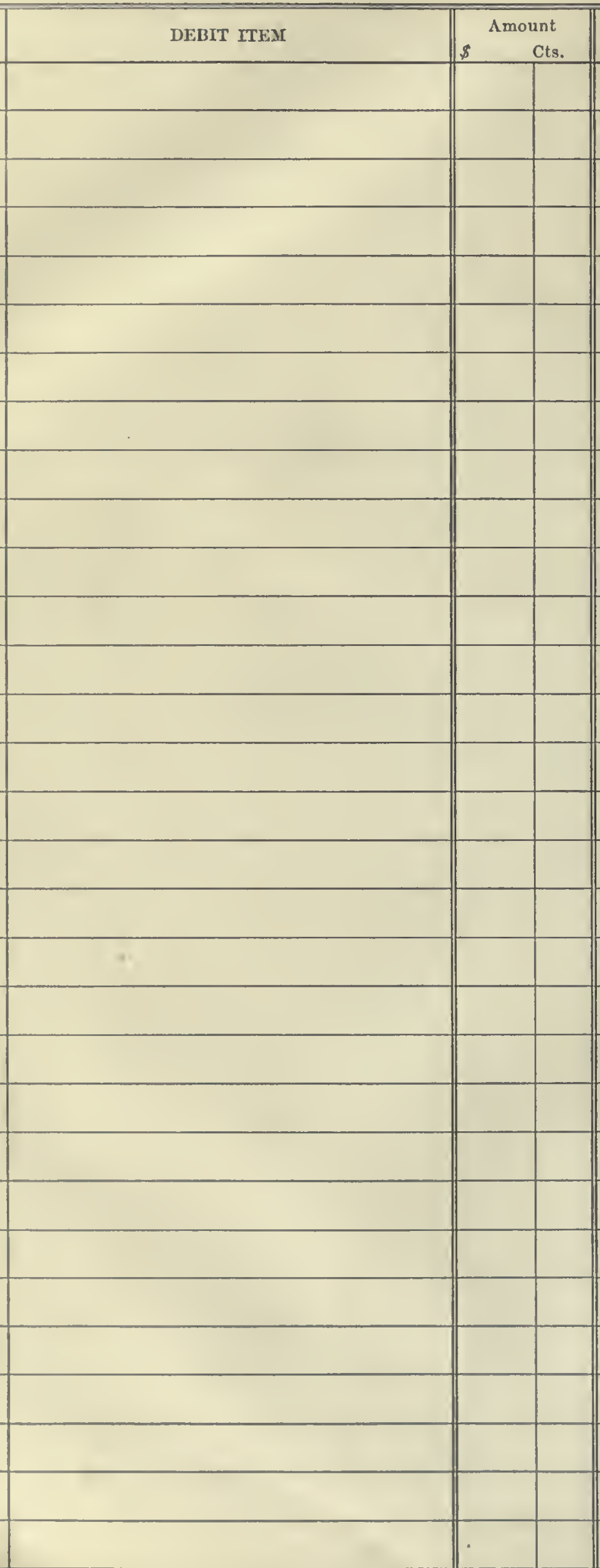

ADDRES5

Euter below cash paid to you, goods delivered to you, work done for you, any article of - value for which you must pay, notes given to you . 
LEDGER ACCOUNT

NAME,

Enter below goods sold by you, cash paid by you, work done by you or your men or teams,
any article of value for which you are to be paid, notes given by you
ADDRESS Enter below cash paid to you, goods delivered to you, work done for you, any article of
value for which you must pay, notes given to you

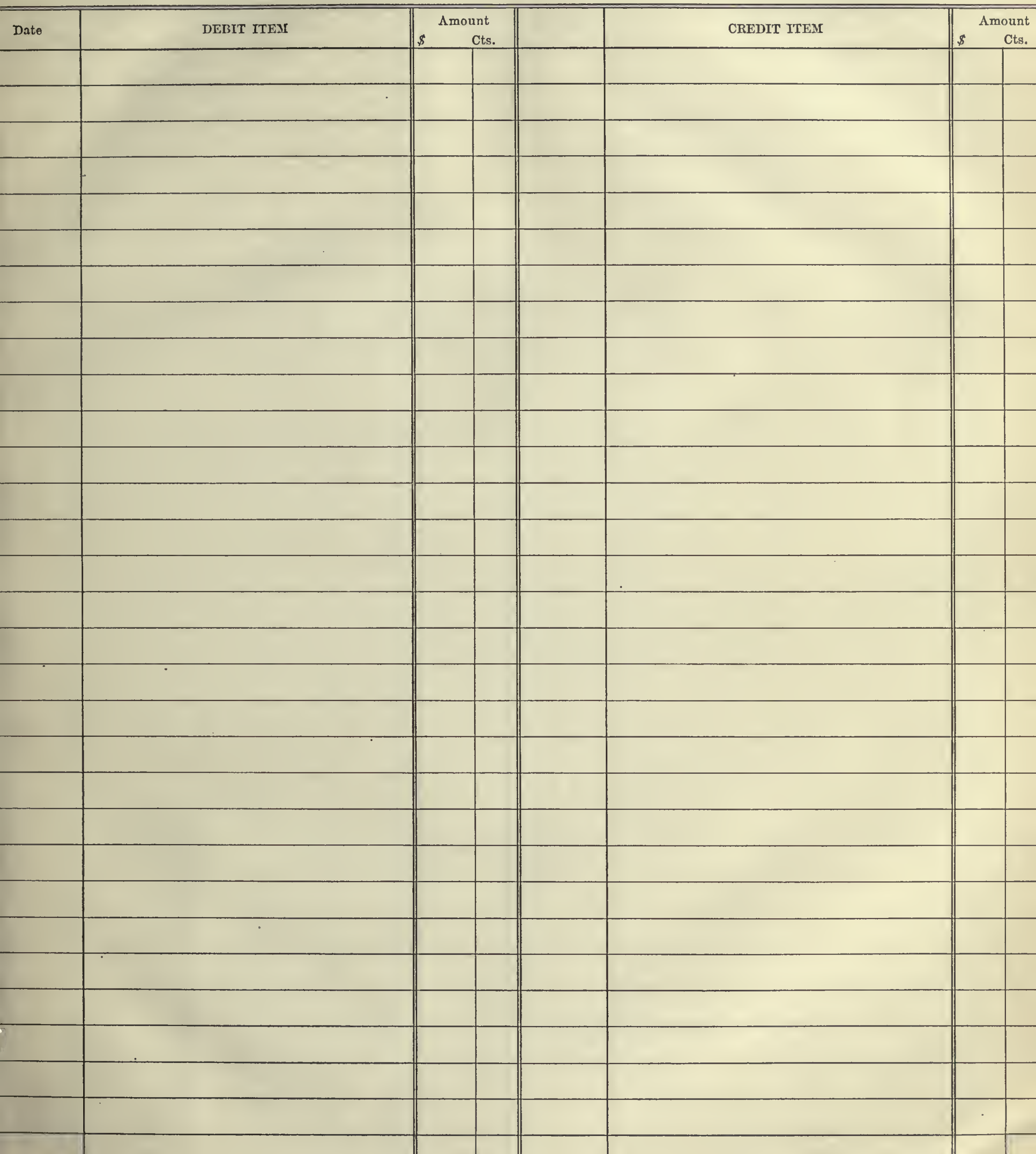


NAME

Enter below goods sold by you, cash paid by you, work" done by you or your men or teams, any article of value for which you are to be paid, notes given by you
ADDRESS

Enter below cash paid to you, goods delivered to you, work done for you, any article of value for which you must pay, notes given to you
CREDIT ITEN
Amoun $s$ 
Enter below goods sold by you, cash psid by you, work done by you or your men or teams, any article of value for which you are to be paid, notes given by you
ADDRESS

Enter below cash paid to you, goods delivered to you, work done for you, any article of value for which you must pay, notes given to you

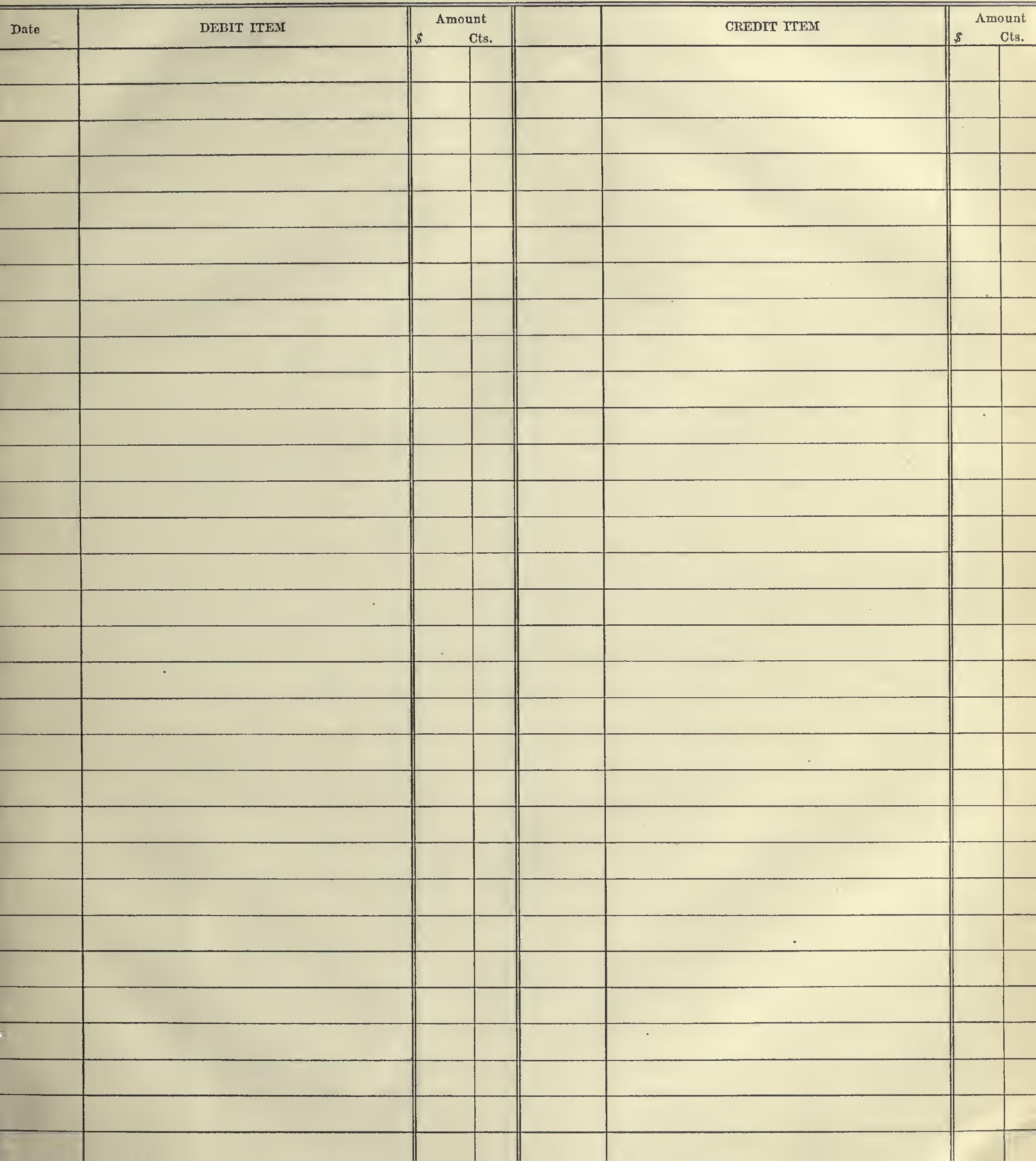


NAME

Enter below goods sold by you, cash paid by you, workd done by you or your men or teams, any article of value for which you are to be pald, notes given by you
ADDRESS

Enter below cash paid to you, goods delivered to you, work done for you, any article of value for which you must pay, n̨otes given to you

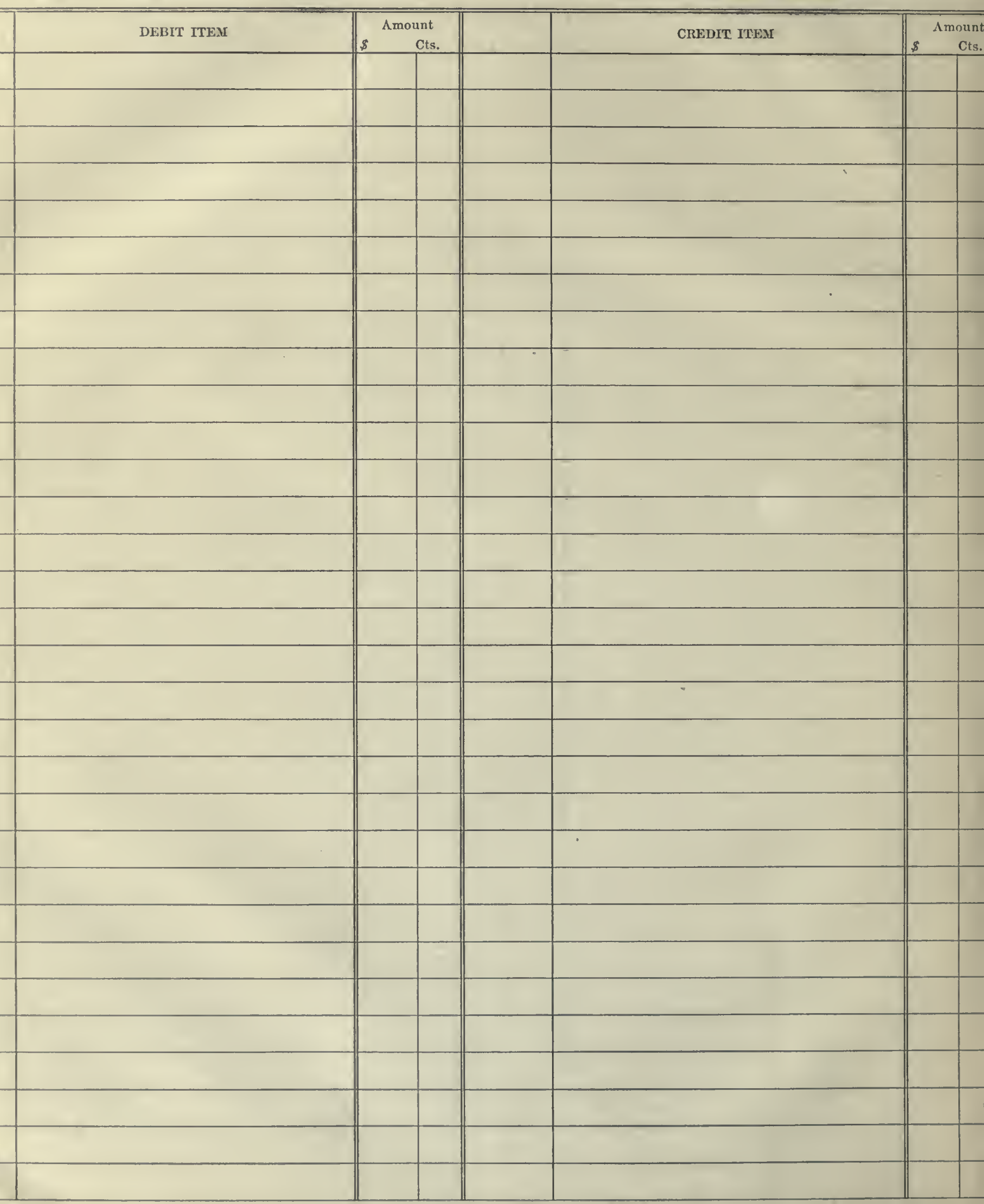


NAME

Enter below goods sold by you, cash paid by you, work done by you or your men or teams, any article of value for which you are to be Daid, notes given by you
ADDRESS

Enter below cash paid to you, goods delivered to you, work done for you, any article of value for which you must pay, notes given to you

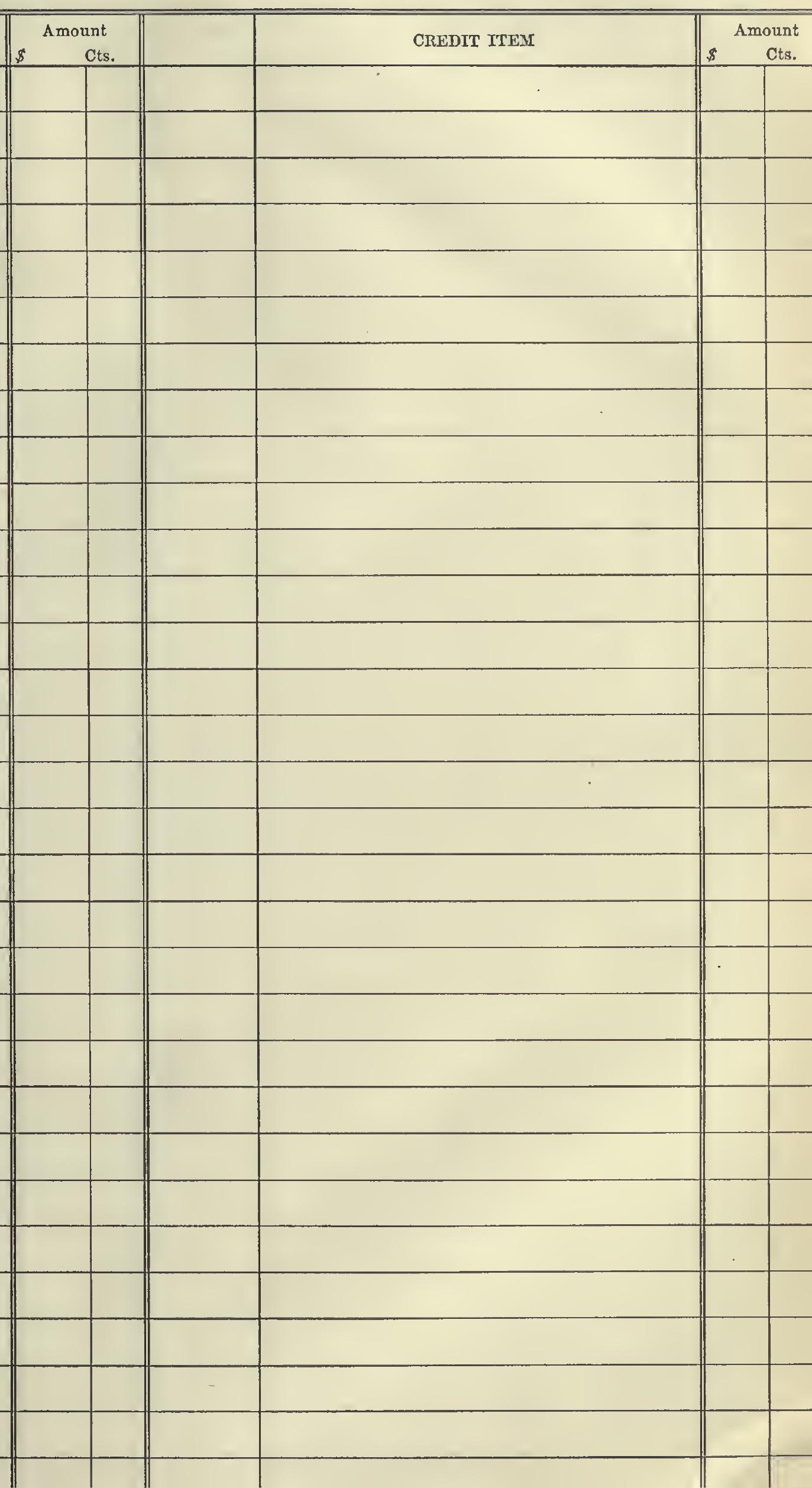


NAME

Fntcr below gooda sold by you, cash paid by you, work done by you or your men or teams any article of value for which you are to be paid, notes given by you
ADDRESS

Enter below cash pald to you, goods delivered to you, work done for you, any article of value for which you must pay, notes given to you -

$\|$

Amount Cts.
CREDIT ITEM
Amount 8 Cts. 


\section{LEDGER ACCOUNT}

NAME

Enter below grods sold by you, eash paid by you, work done by you or your men or teams, any article of value for which you are to be paid, notes given by you
ADDRESS

Enter below cash paid to you, goods delivered to you, work done for you, any article of value for which you must pay, notes given to you

\section{Date}

DEBIT ITEM

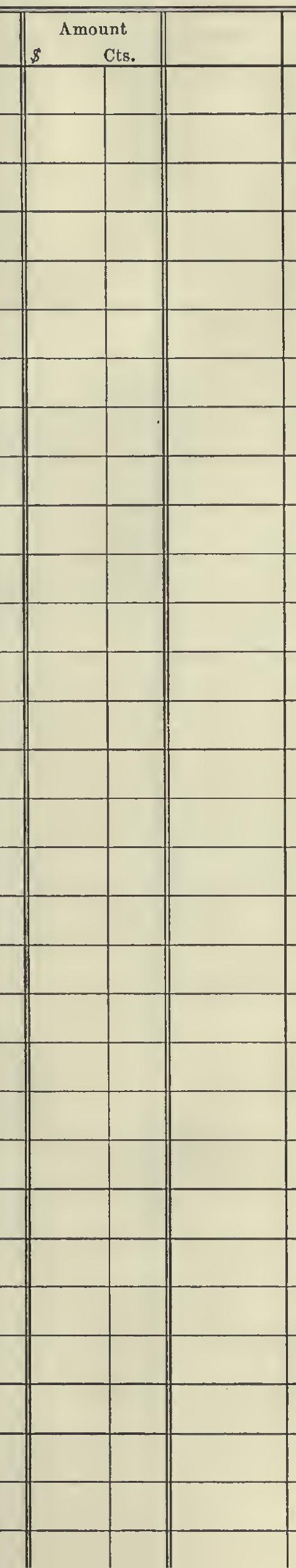

CREDIT ITEMI

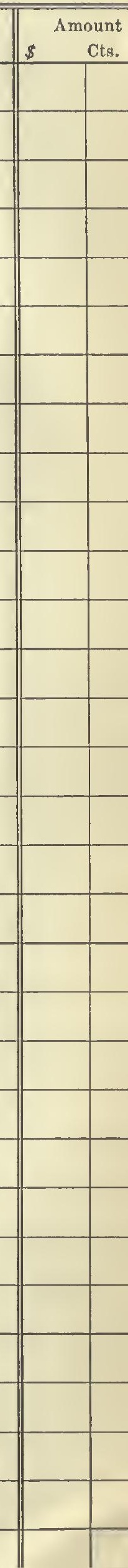


NAME

Enter below goods sold by you, cash paid by you, work done bry you or youtr men or teams, any article of value for which you are to be paid, notes given by sou
ADDRESS

Enter below cash paid to you, goods delivered to you, work done for you, any article of value for which you must pay, notes given to you

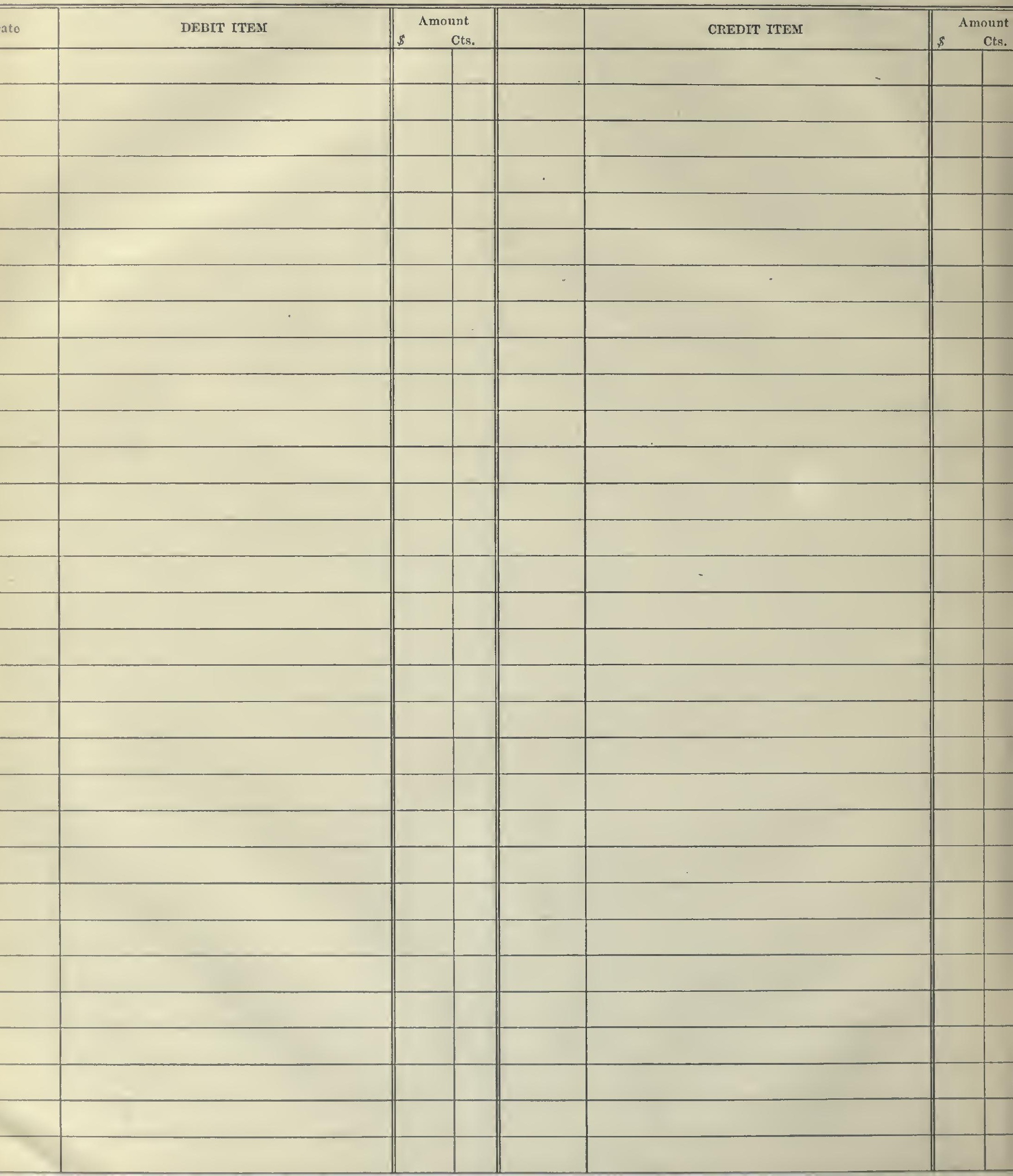




\section{LEDGER ACCOUNT}

NAME

Enter below goods sold by you, cash paid by you, work done by you or your men or teams, any article of value for which you are to be paid, notes given by you
ADDRESS

Enter below cash paid to you, goods delivered to you, work done for you, any article of value for which you must pay, notes given to you

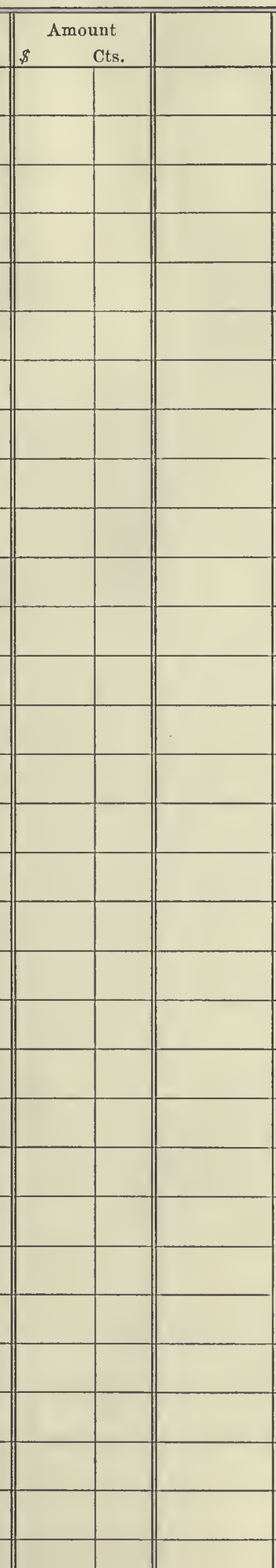

CREDIT ITEM

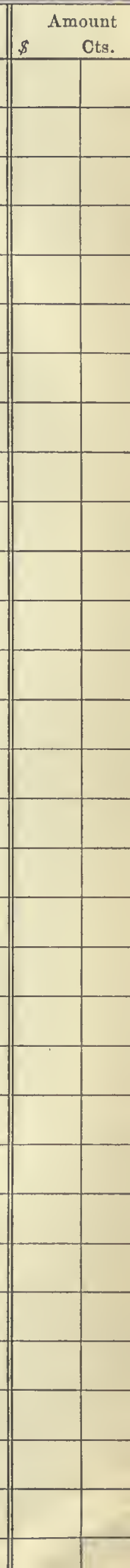


NAME

Enter below goods sold by you, cash paid by you, work done by you or your men or teams. any article of value for which you are to be paid, notes given by you

DEBIT TTEM Cts.
ADDRESS

Enter below cash paid to you, goods delivered to you, work done for you, any article of value for which you must pay, notes given to you

1

\$ $\begin{array}{rr}\text { Amount } \\ \text { Cts. }\end{array}$

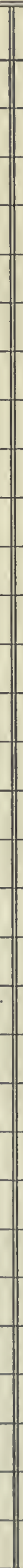

CREDIT ITEM
Amount 5 Cts. 
NAME

Enter below goods sold by you, cash paid by you, work done by you or your men or teams, any article of value for wbich you are to be paid, notes given by you

\section{ADDRESS}

Enter below cash paid to you, goods delivered to you, work done for you, any article of value for which you must pay, notes given to you

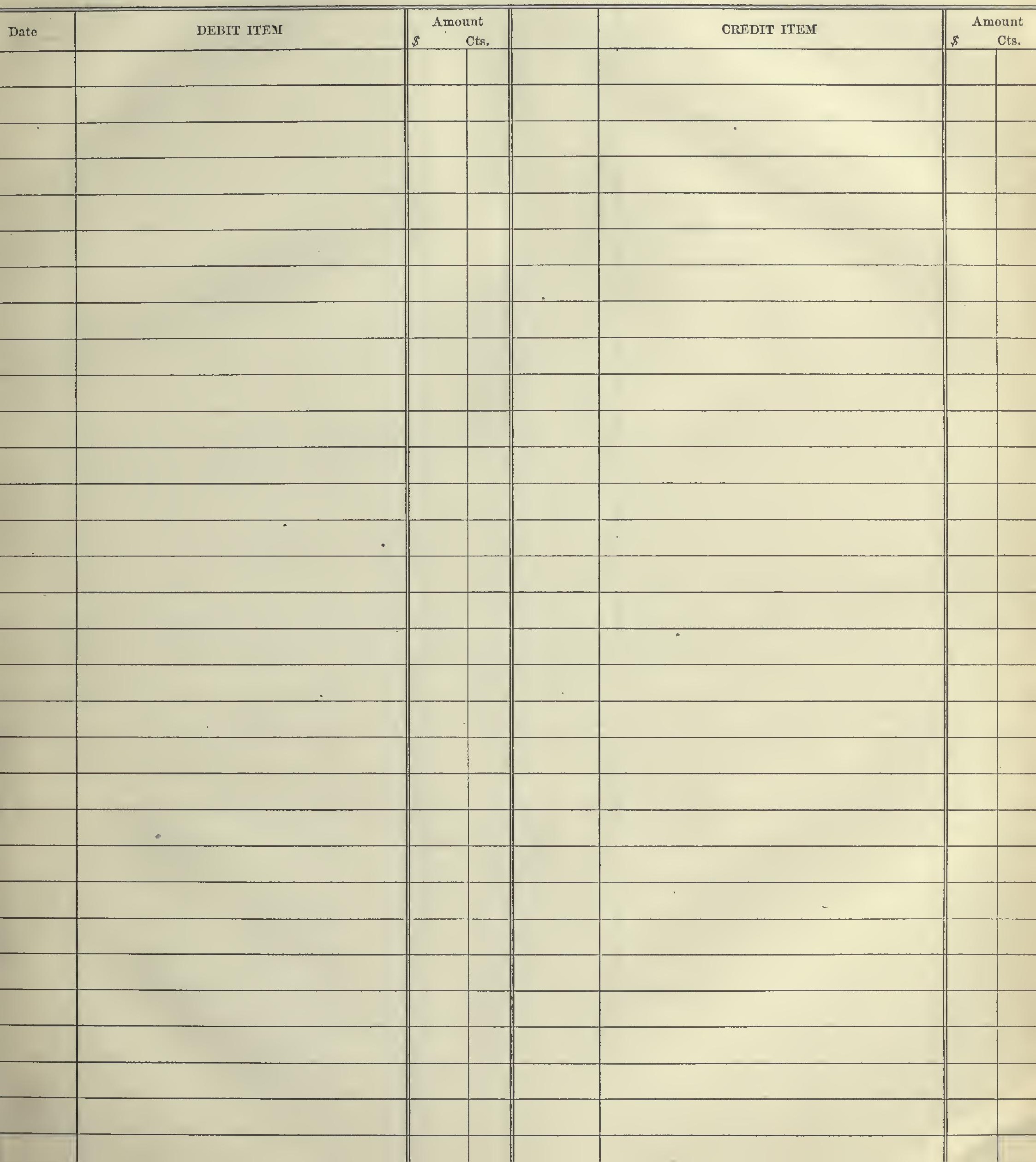


NAME

Enter below goods sold by you, cash paid by you, work done by you or your men or teams, any article of value for which you are to be paid, notes given by you
ADDRESS

Enter below cash paid to you, goods delivered to you, work done for you, any article of value for which you must pay, notes given to you

DEBIT ITEXI

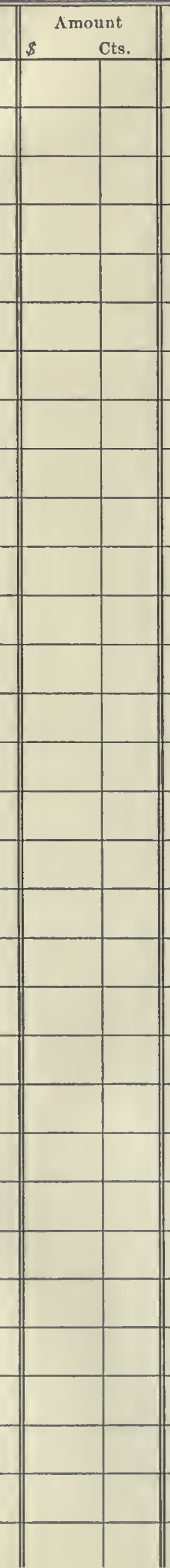

CREDIT ITE

Amount 
NAME

Enter below goods sold by you, cash paid by you, work done by you or your men or teams, any article of value for which you are to be paid, notes given by you
ADDRESS

Enter below cash paid to you, goods delivered to you, work done for you, any articlc of value for which you must.pay, notes given to you

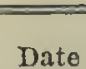

DEBIT ITEM

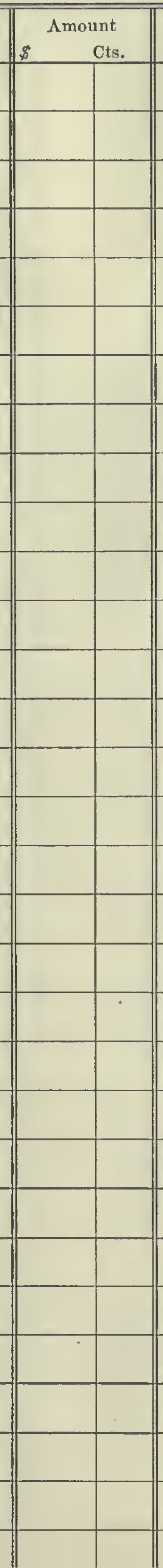

CREDIT ITEMI
Amount $\$ \quad$ Cts. 
Naye

Enter below goods sold by you, cash paid by you, work done by you or your men or teams, any article of value for which you are to be paid, notes given by you

DEBIT ITEM

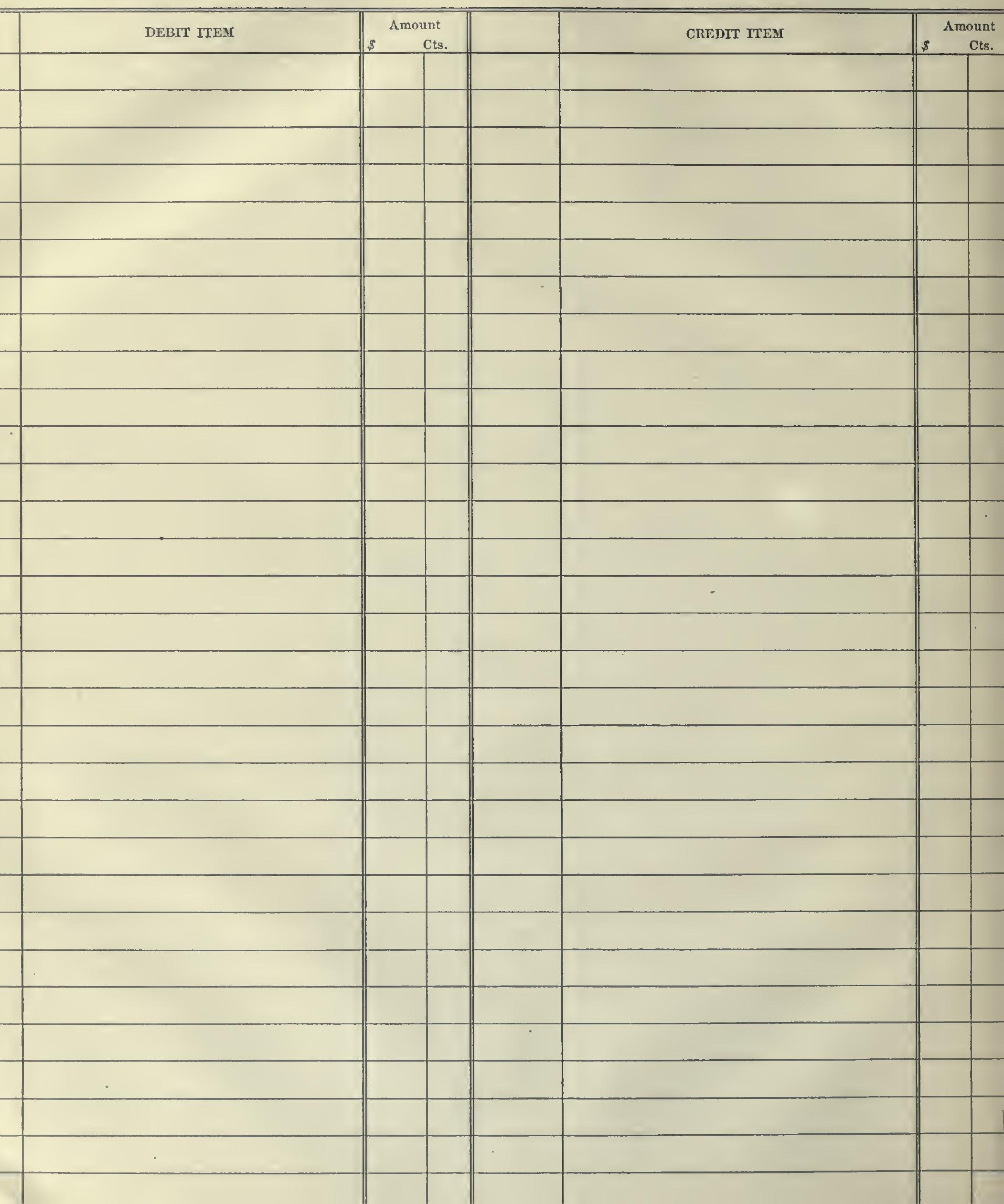

ADDRESS

Enter below cash paid to you, goodg delivered to you, work done for you, any article of value for which you must pay, notes given to you 

NAME
Enter below goods sold by you, cash paid by you, work done by you or your men or teams,
any article of value for which you are to be paid, notes given by you
ADDRESS

Enter below cash paid to you, goods delivered to you, work done for you, any article of value for which you must pay, notes given to you 
NAME

Enter below goods sold by you, cash paid by you, work done by you or your men or teams, any article of value for which you are to be paid, notes given by you
Amount
ADDRESS

Enter below cash paid to you, goods delivered to you, work done for you, any article of value for which you must pay, notes given to you
CREDIT ITEM

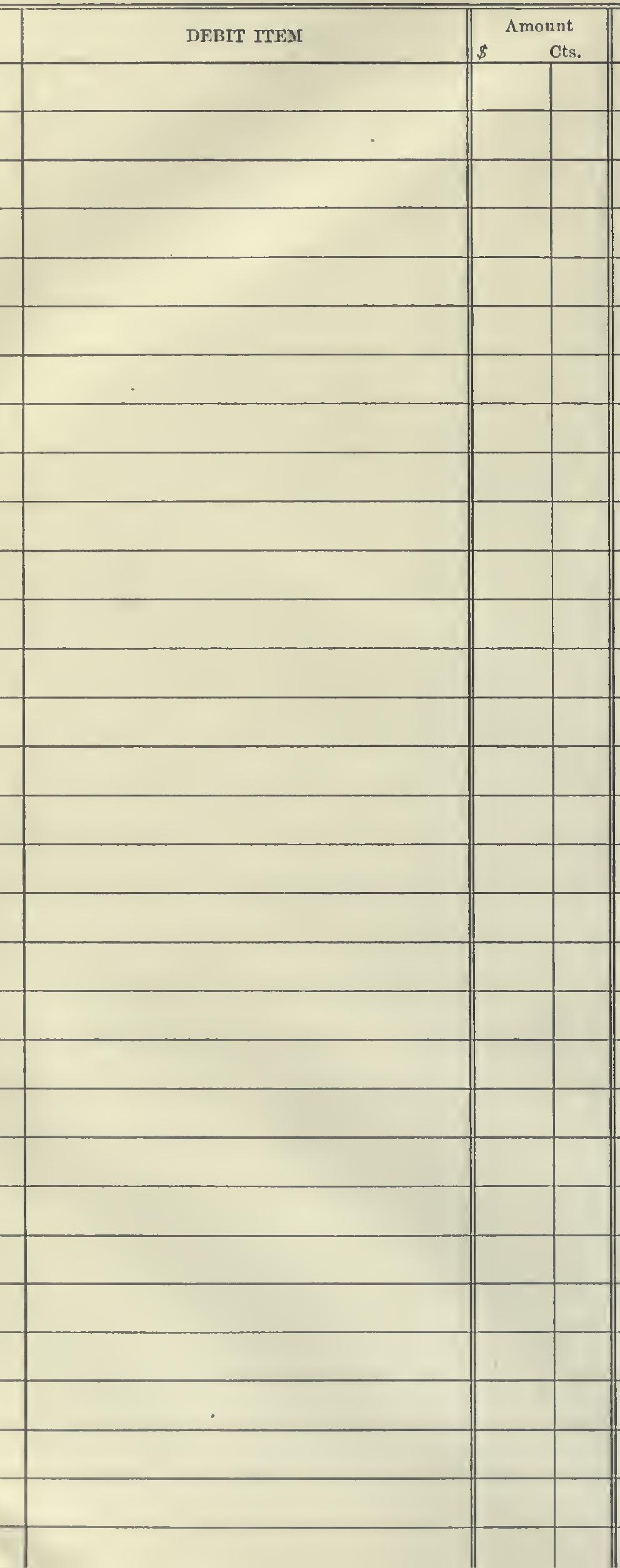

Amount 


\section{NAME}

Enter below goods sold by you, cash paid by you, work done by you or your men or teams, any article of value for which you are to be paid, notes given by you

\section{ADDRESS}

Enter below cash paid to you, goods delivered to you, work done for you, any article of value for which you must pay, notes given to you

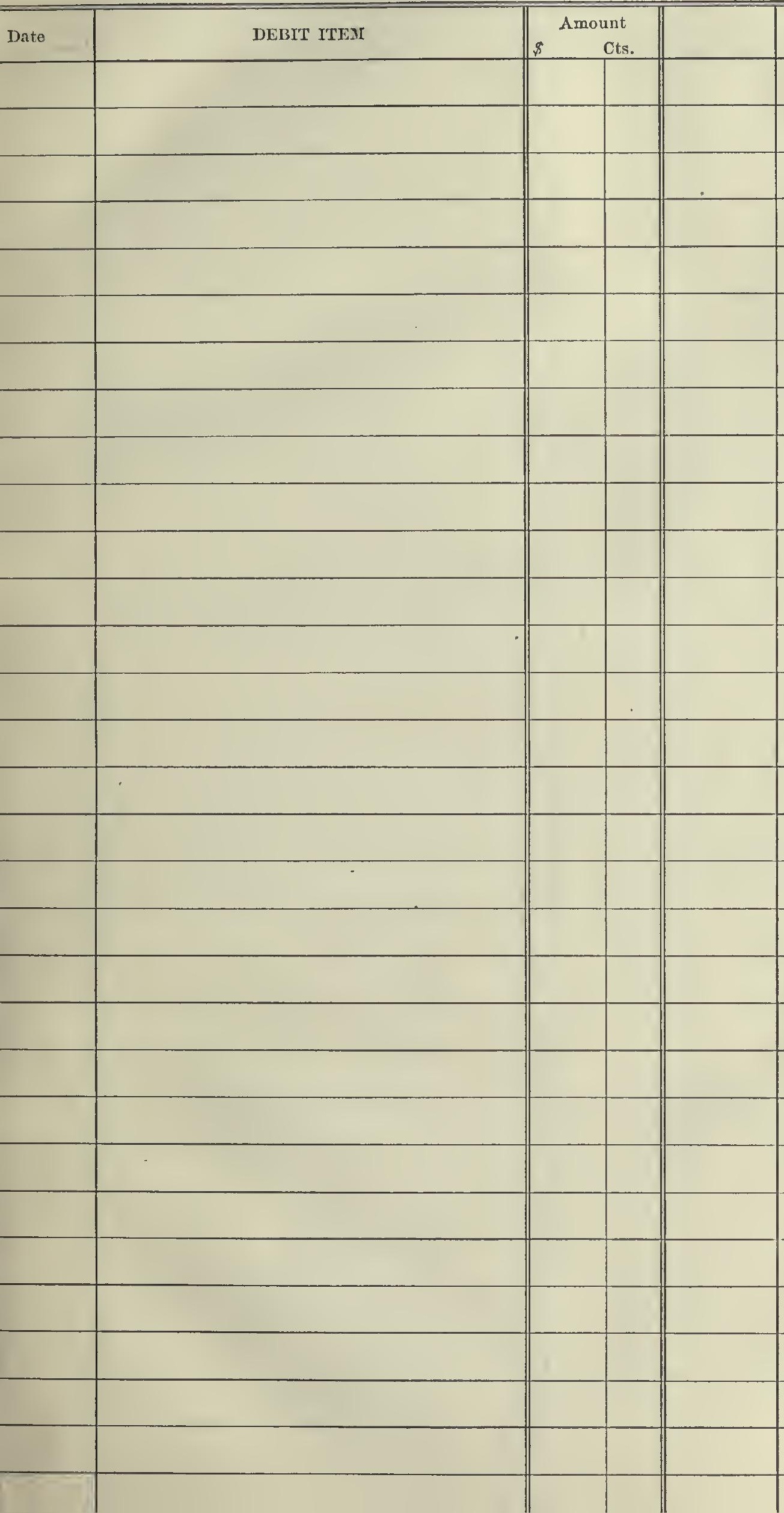

CREDIT ITEM
Amount $\$ \quad$ Cts. 
NAME

Enter below goods sold by you, cash paid by you, work done by you or your men or teams, any article of value for which you are to be paid, notes given by sou
ADDRESS

Enter below cash paid to you, goods delivered to you, work done for you, any article of value for which you must pay, notes given to you

\section{DEBIT ITEM}

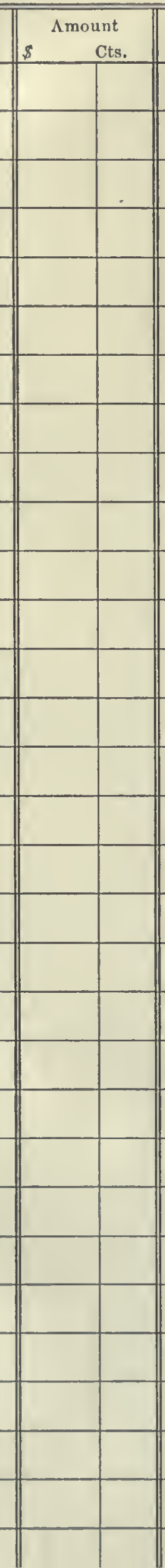

Amount 
LEDGER ACCOUNT

23

Name Enter below goods sold by you, cash paid by you, work done by you or your men or teams,
any article of value for which you are to be paid, notes given by you
ADDRESS Enter below cash paid to you, goods delivered to you, work done for you, any article of
value for which you must pay, notes given to you

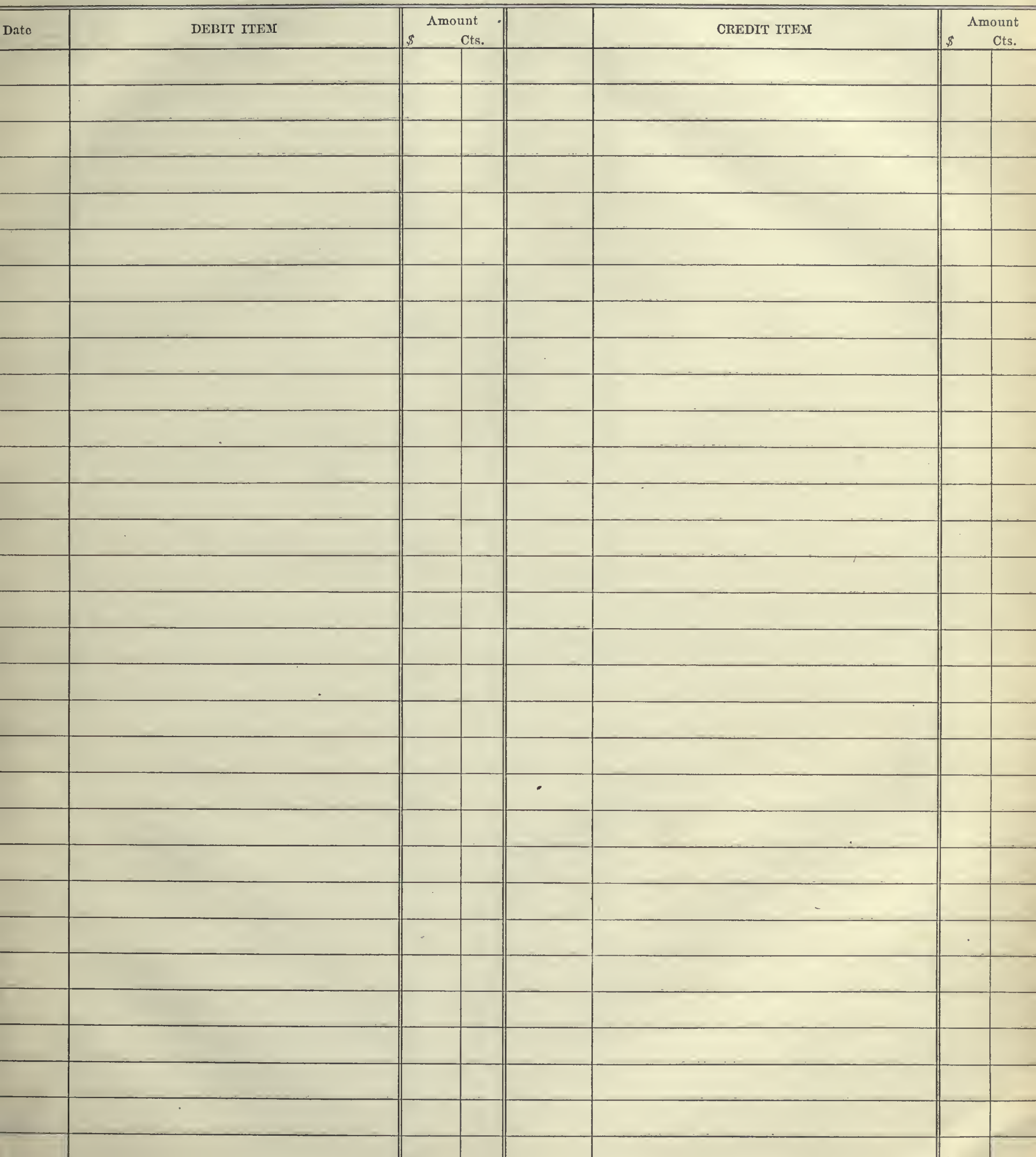


Enter below goods sold by you, cash paid by you, work done by you or your men or teams, any article of value for which you are to be paid. notes given by you

Enter below cash paid to you, goode delivered to you, work done for you, any article of value for which you must pay, notes given to you 


\section{LEDGER ACCOUNT}

NAME

Enter below goods sold by you, cash paid by you, work done by you or your men or teams, any article of value for which you are to be daid, notes given by you
ADDRESS

Enter below cash paid to you, goods delivered to you, work done for you, any article of value for which you must pay, notes given to you
DEBIT ITEM

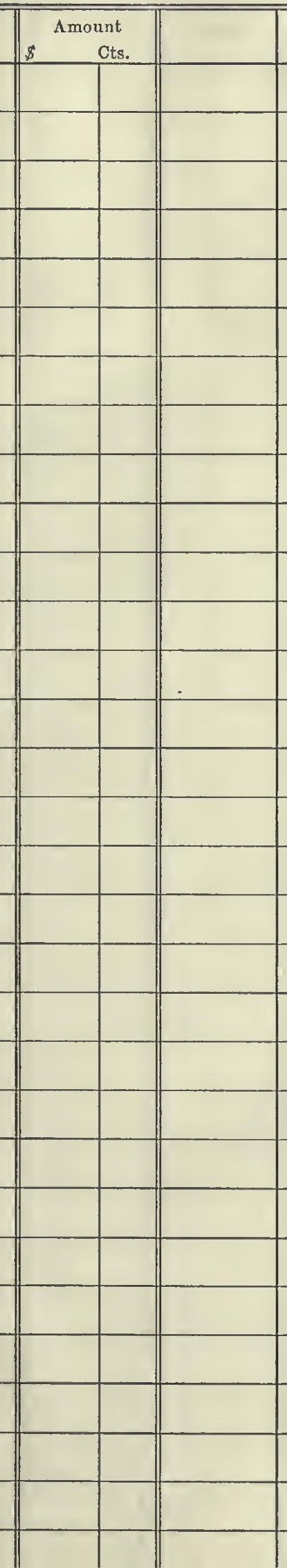

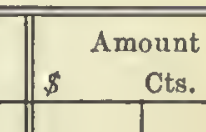


NAME

Enter below goods sold by you, cash paid by you, work done by you or your men or teams. . any article of value for which you are to be paid, notes given by sou

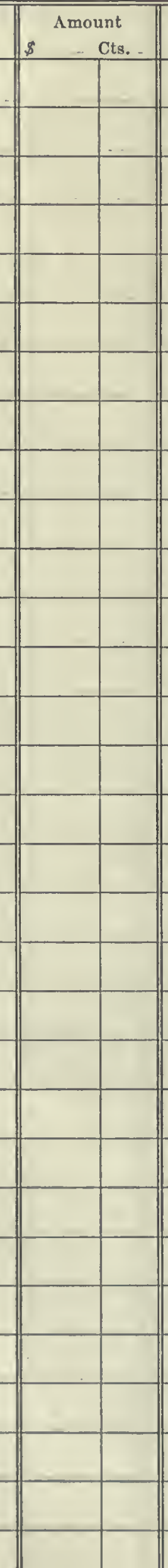

ADDRESS

Enter below cash paid to you, goods delivered to you, work done for you, any article of alue for which you must pay, notes given to you

Date

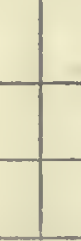

DEBIT ITEMI

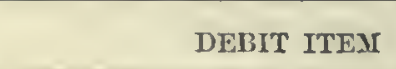


NAME

Enter below goods sold by you, cash paid by you, work done by you or your men or teams, any article of value for which you are to be paid, notes given by you
ADDRESS

Enter below cash paid to you, goods delivered to you, work done for you, any article of value for which you must pay, notes given to you

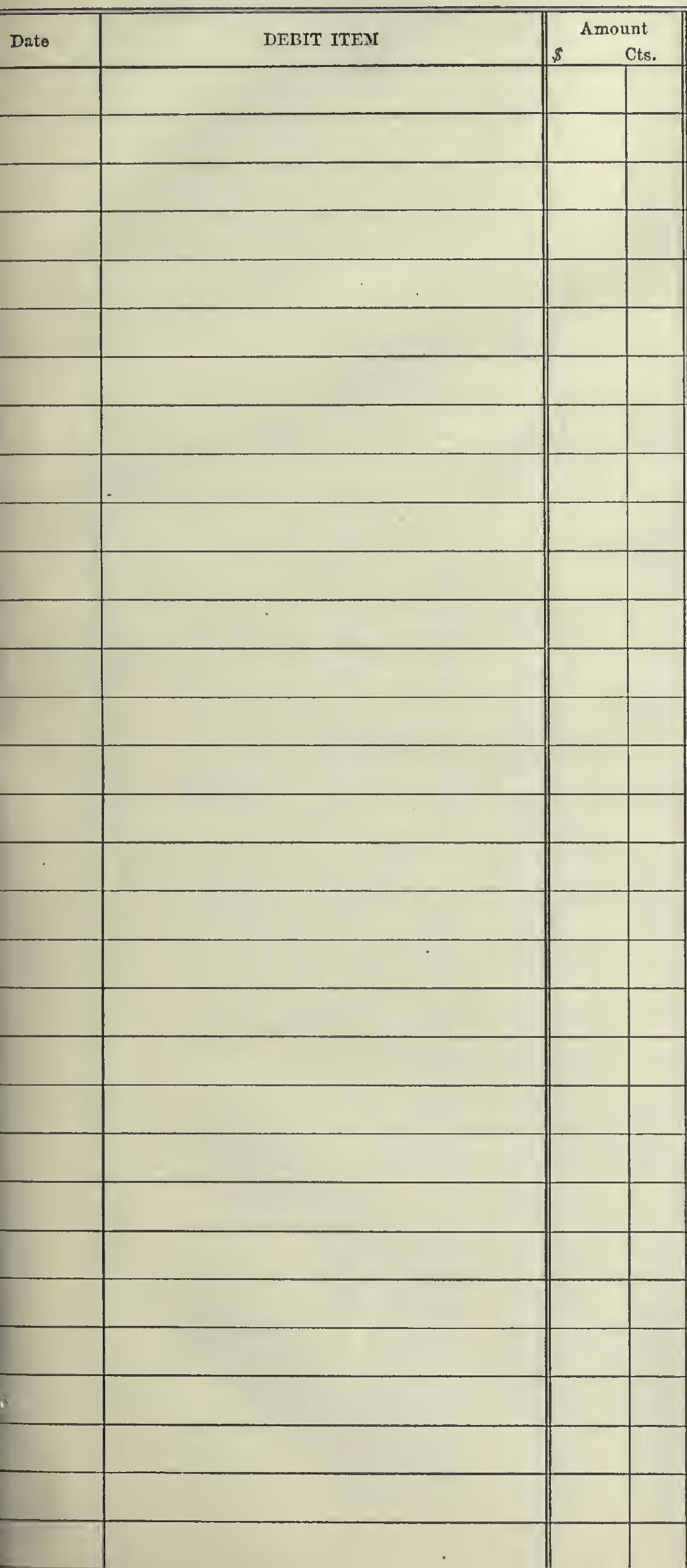

CREDIT ITEM

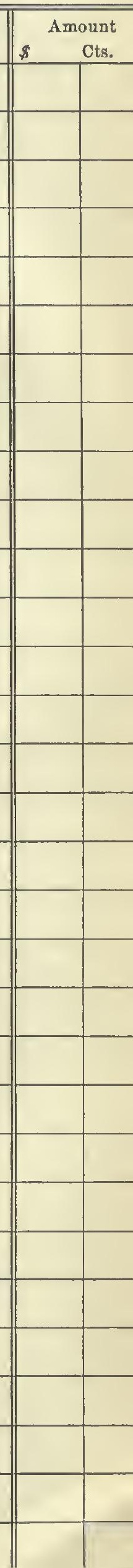


NAME

Enter below goods sold by you, cash paid by you, work done by you or your men or teams, any article of value for which you are to be paid, notes given by you
ADDRESS

Enter below cash paid to you, goods delivered to you, work done for you, any article of value for which you must pay, notes given to you.
DEBIT ITEM

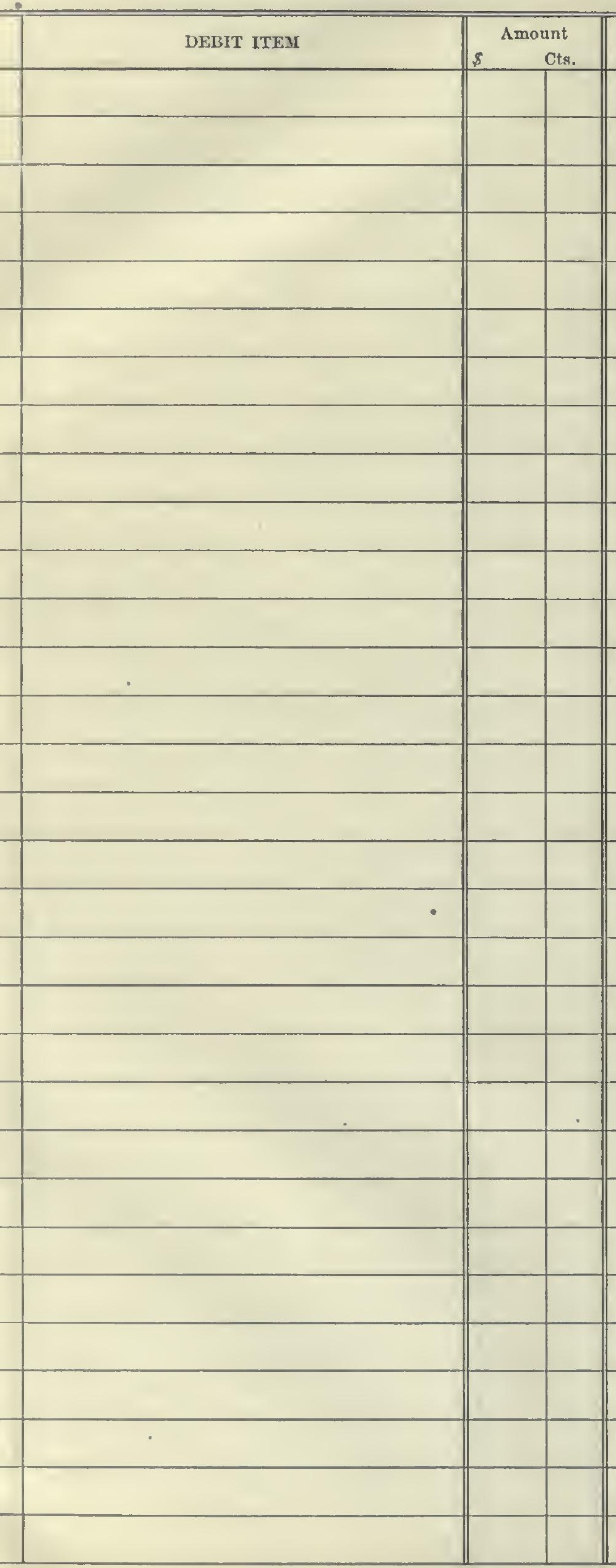

Date
CREDIT ITEMI

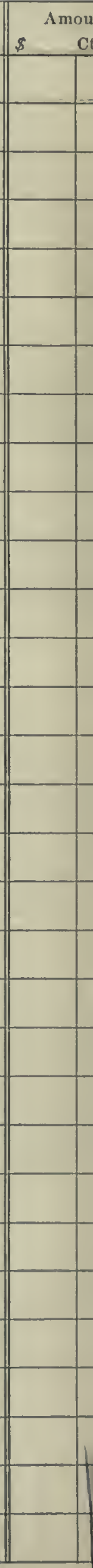


NAME

Enter below goods sold by you, cash paid by you, work done by you or your men or teams, any article of value for which you are to be paid, notes given by you
ADDRESS

Enter below cash paid to you, grods delivered to you, work done for you, any article of value for which you must pay, notes given to you

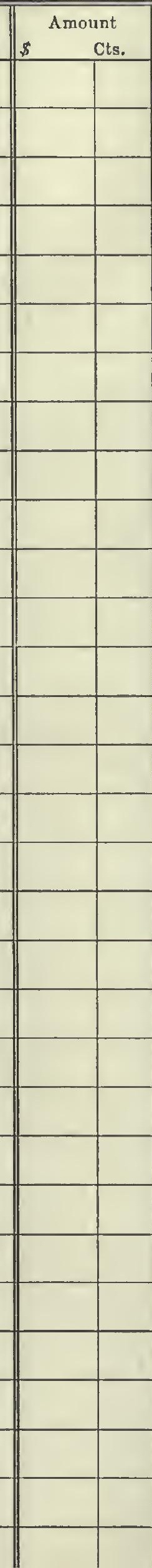

CREDIT ITEM
Amount $\$$ Cts. 


\section{LEDGER .ACCOUNT}

NAME.

Enter below grods sold by you, cash paid by you, work done by you or your men or teams, any article of value for which you are to be paid, notes given by you

\section{Amount} Cts.
ADDRESS

Enter below cash paid to you, geods delivered to you, work done for you, any article of - value for which you must pay, notes given to you
CREDIT ITEM 
NAME

Enter below goods sold by you, essh paid by you, work done by you or your men or teams, any article of value foz which you are to be paid, notes given by you
ADDRESS

Enter below cash paid to you, goods delivered to you, work done for you, any article of value for which you must pay, notes given to you

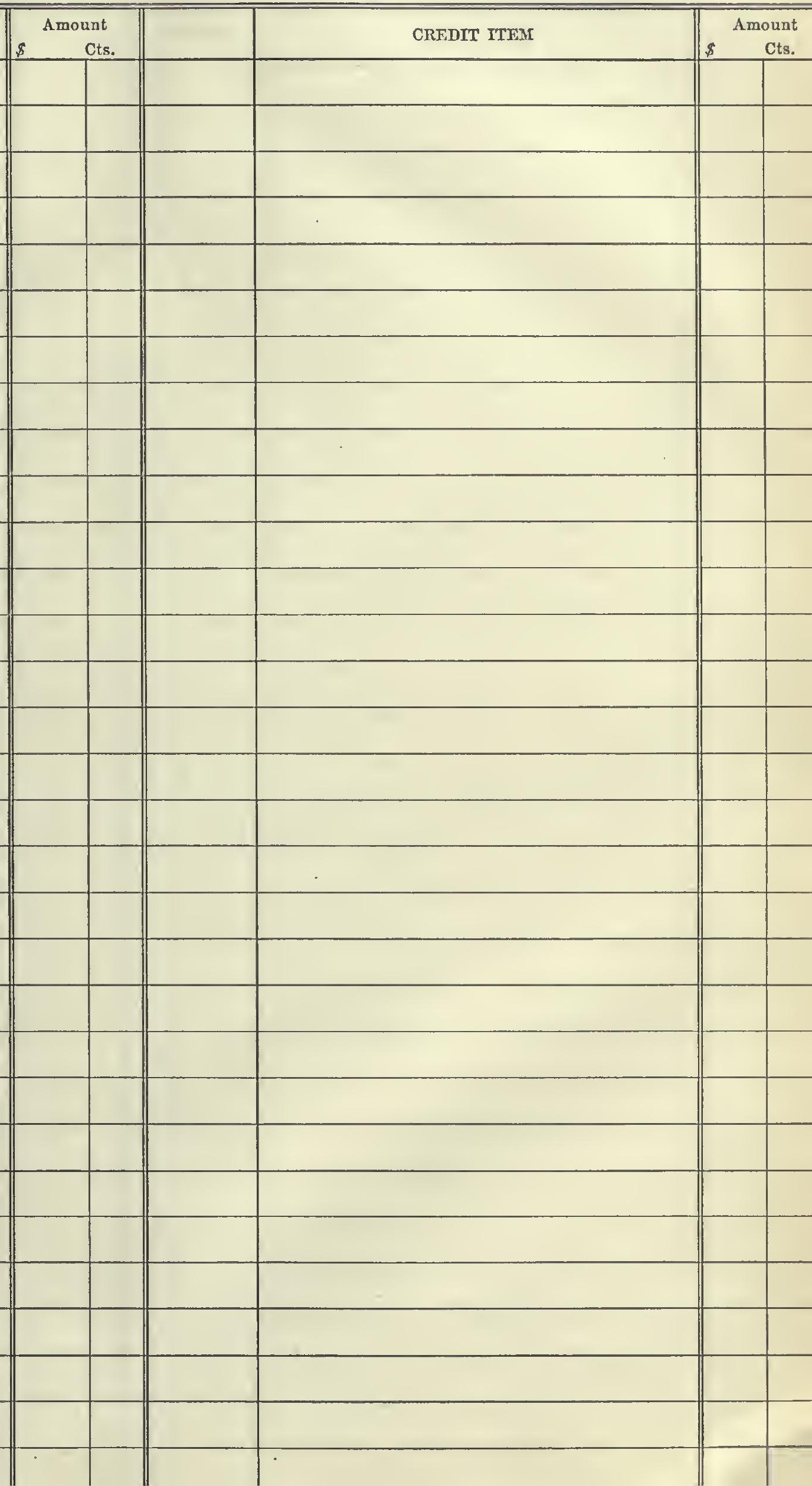


LEDGER .ACCOUNT

NAME

ADDRESS Enter below goods sold by you, cash paid by you, work done by you or your men or teams,
ny article of value for which you are to be paid, notes given by you Enter below cash paid to you, goods delivered to you, work done for you, any article of
value for which you must pay, notes given to you

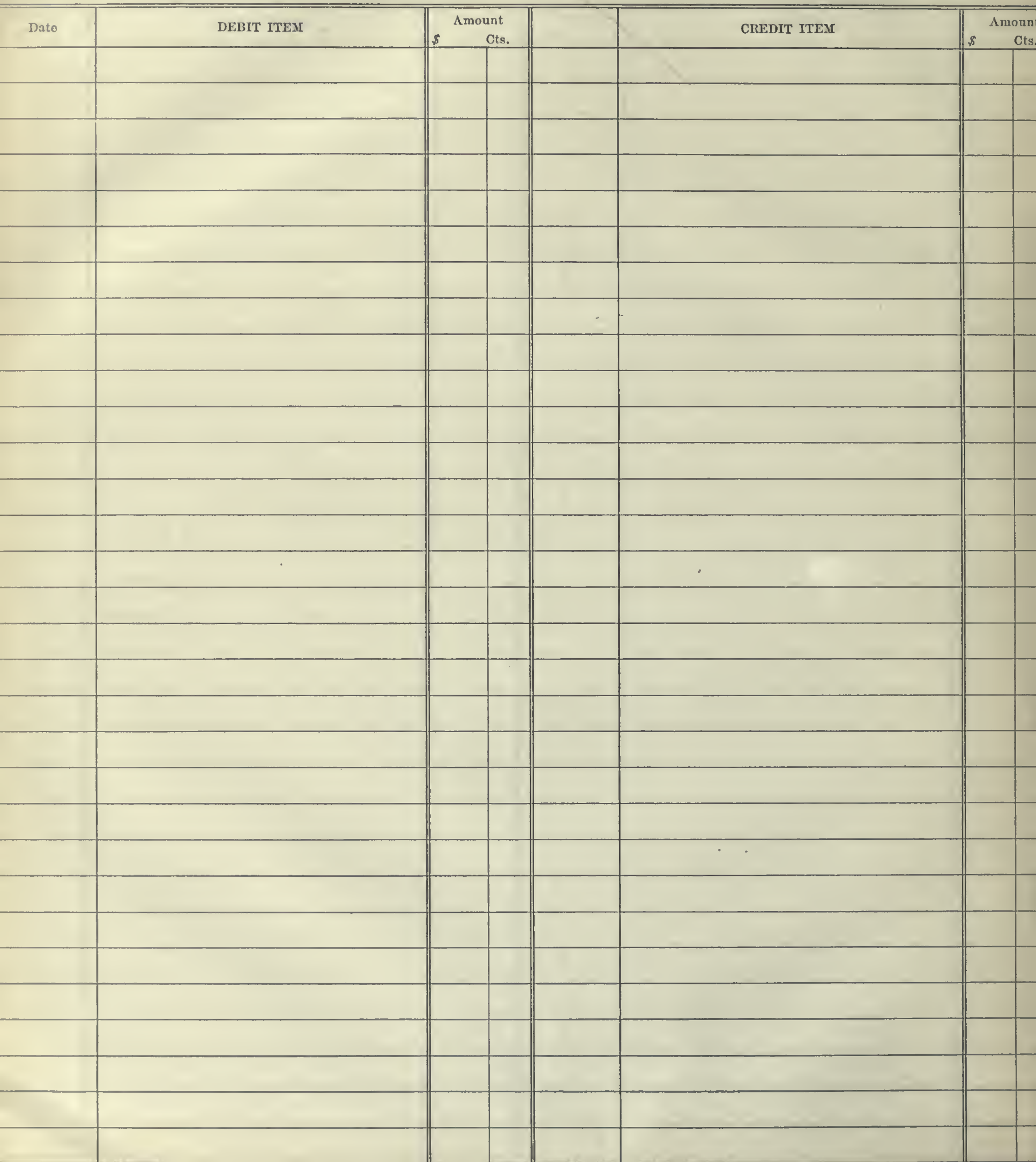


NAME

Enter below goods sold by you, cash paid by you, work done by you or your men or teams, any article of value for wbieb jou are to be paid, notes given by you
ADDRESS

Enter below cash paid to you, goods delivered to you, work done for you, any article of value for which you inust pay, notes given to you

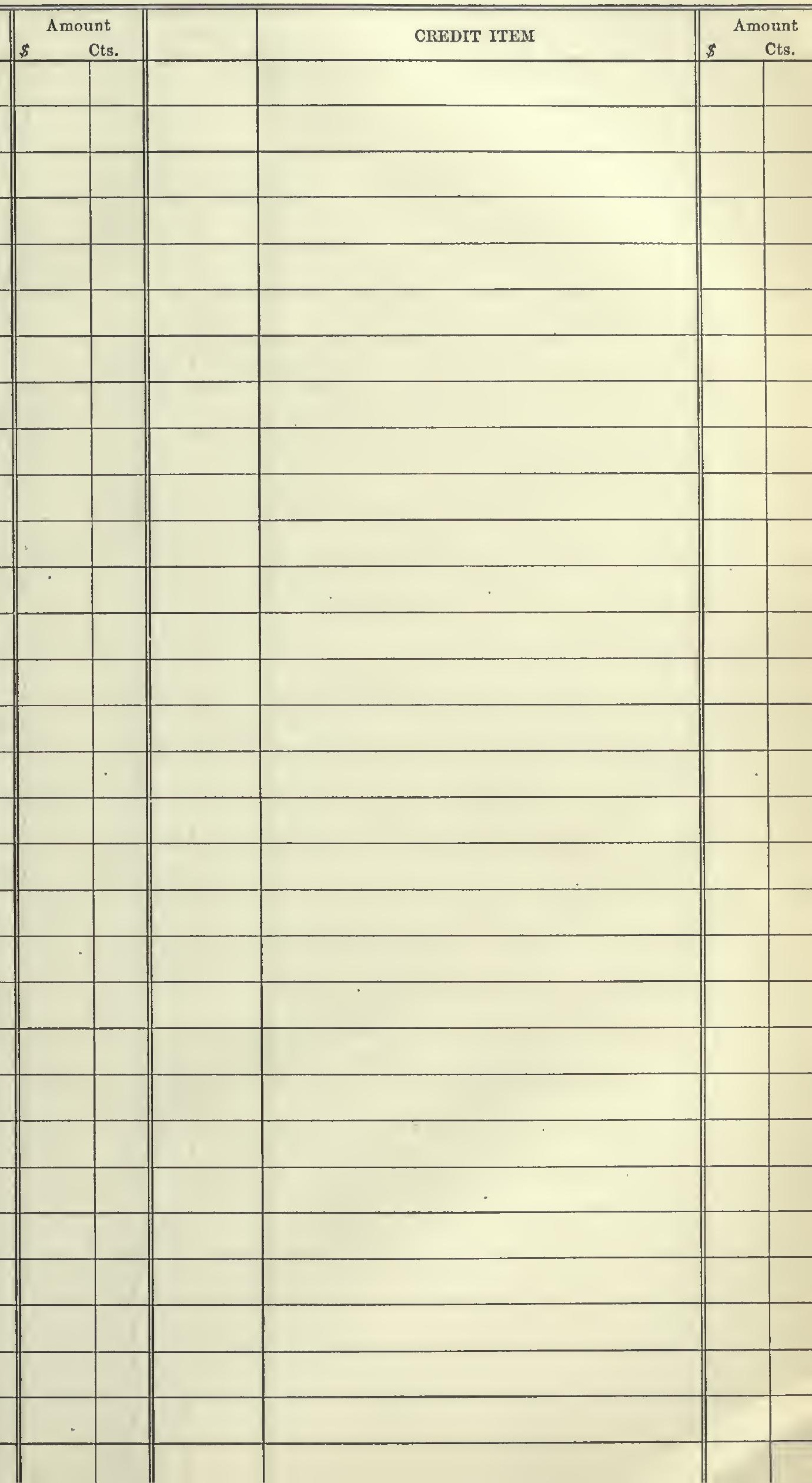


NAME

Enter below goods sold by you, cash paid by you, work done by you or your men or tearns, any article of value for which you are to be paid, notes given by you
ADDRESS

Enter below cash paid to you, goods delivered to you, work done for you, any article of value for which you must pay, notes given to you

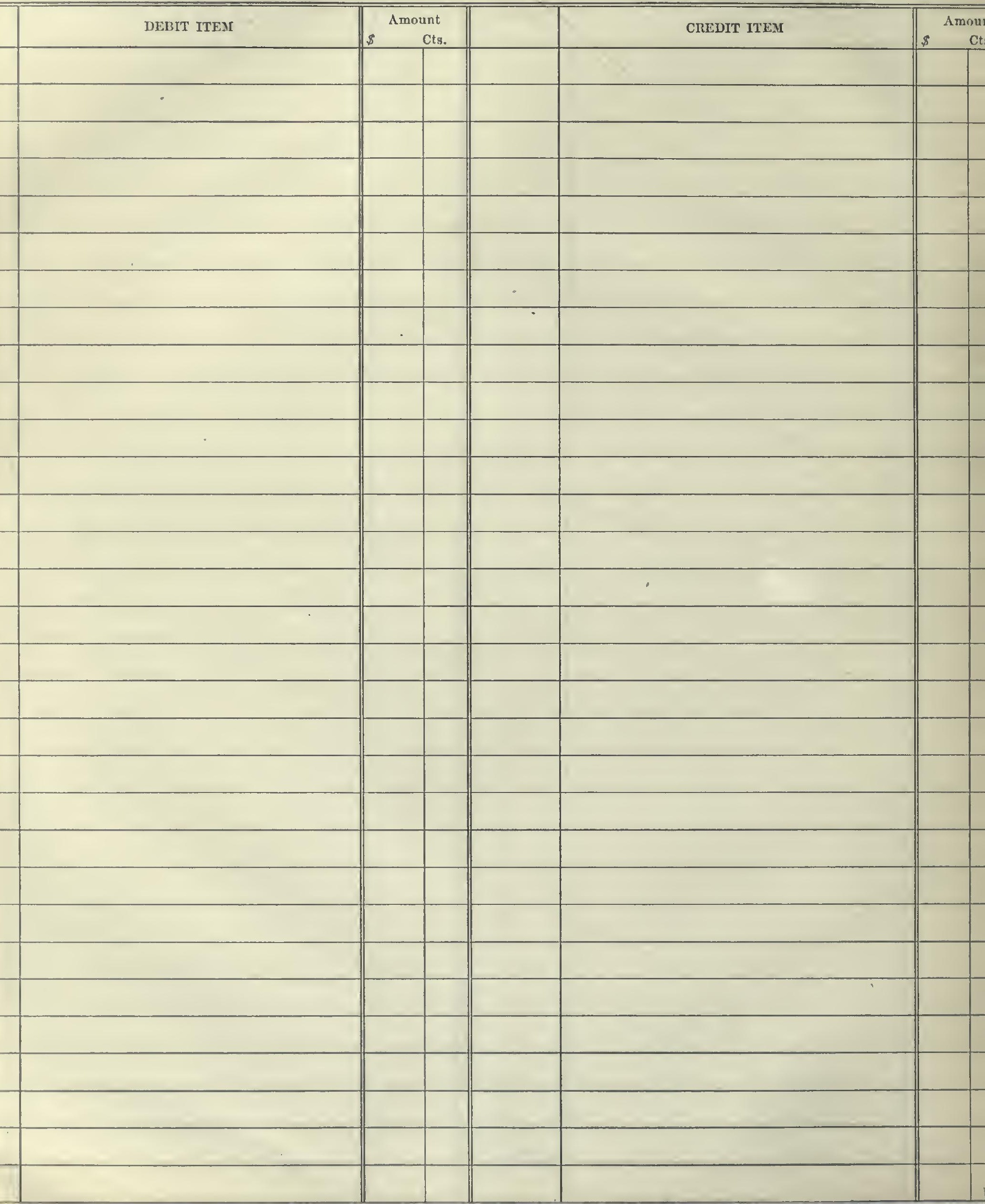


LEDGER ACCOUNT

NAME Enter below goods sold by you, cash paid by you, work done by you or your men or teams,
ny article of value for which you are to be paid, notes given by you
ADDRESS Enter below cash paid to you, goods delivered to you, work done for you, any article of
value for which you must pay, notes given to you

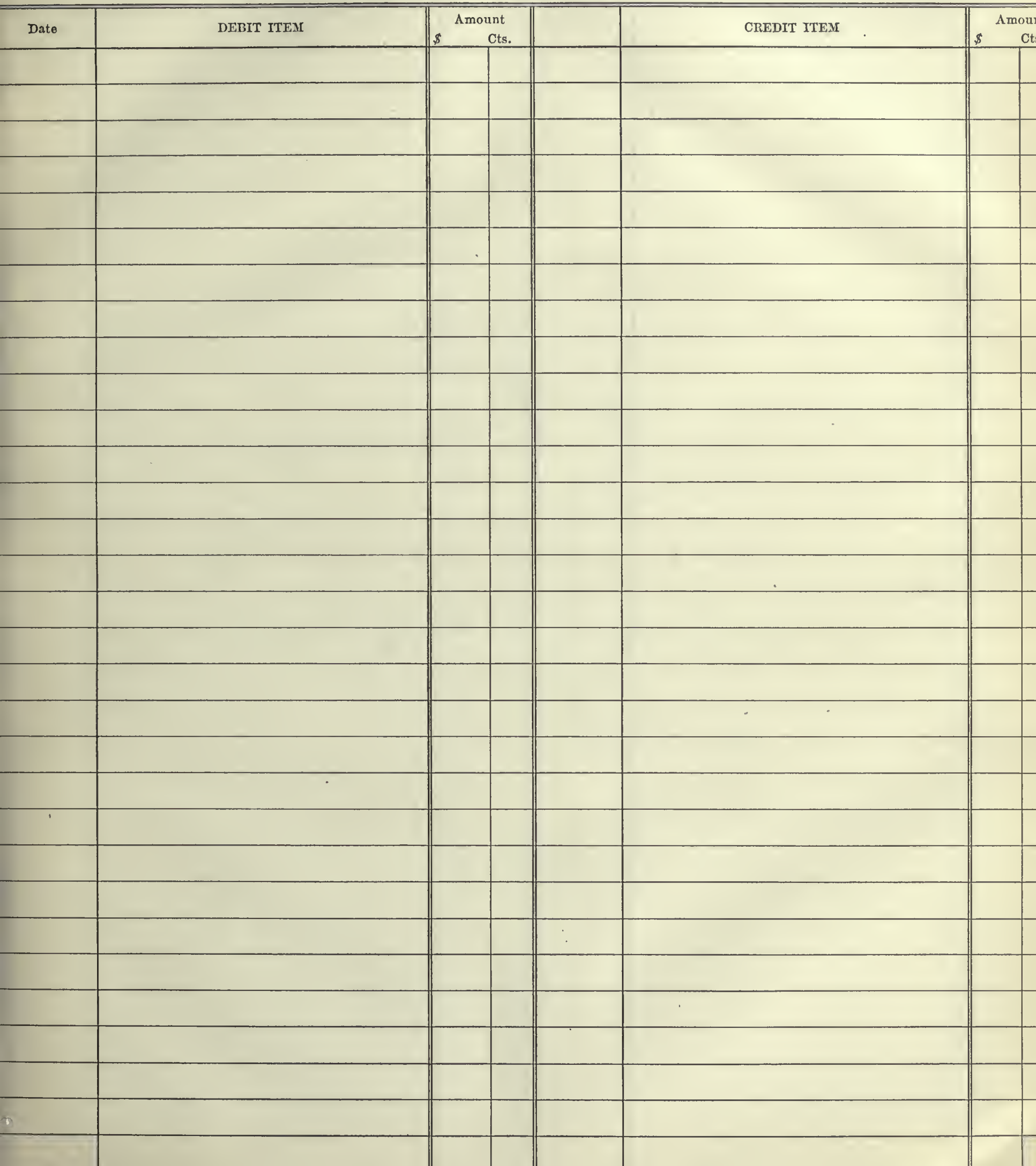


NAME

Enter below goods sold by you, cash paid by you, work done by you or your men or teams, any article of value for which you are to be paid, notes given by you

DEBIT ITEXY

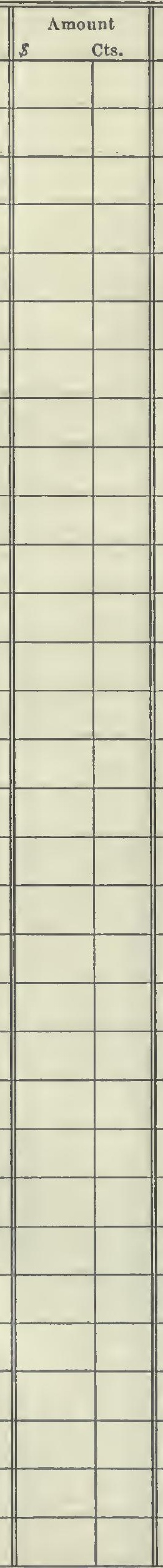

ADDRESS

Enter below cash paid to you, goods delivered to you, work done for you, any article of value for which you must pay, notes given to you 
NAME

Enter below goods sold by you, cash paid by you, work done by you or your men or teams any article of value for which you are to be paid, notes given by you

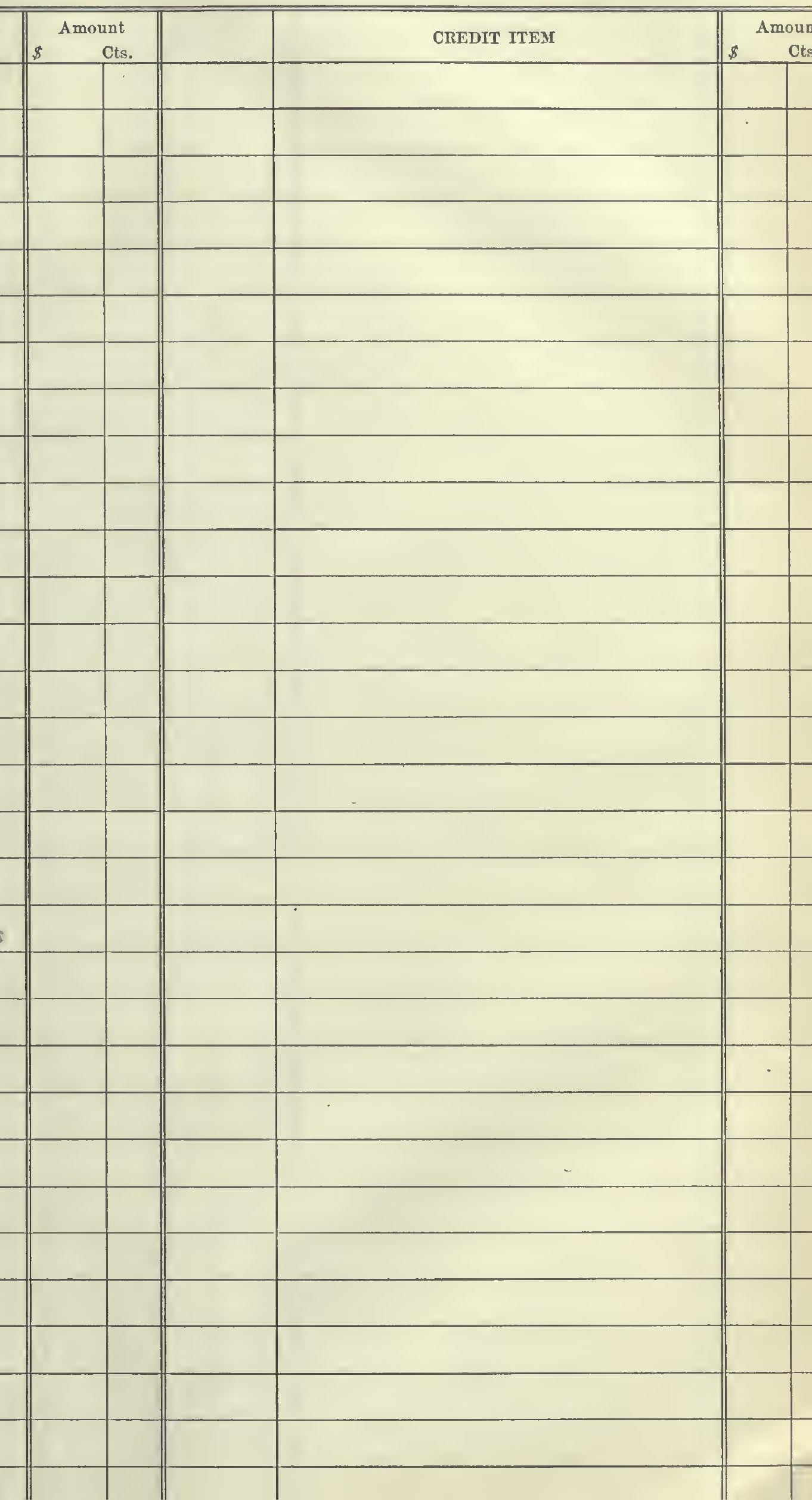

\section{DEBIT ITEגI}


NAME Enter below groods sold by you, eash paid by you, work done by you or your men or teans.
any article of value for which you are to be paid, notes given by you

DEBIT ITEM
ADDRESS

Enter below cash paid to you, goods delivered to you, work done for you, any article of value for which you must pay, notes given to you

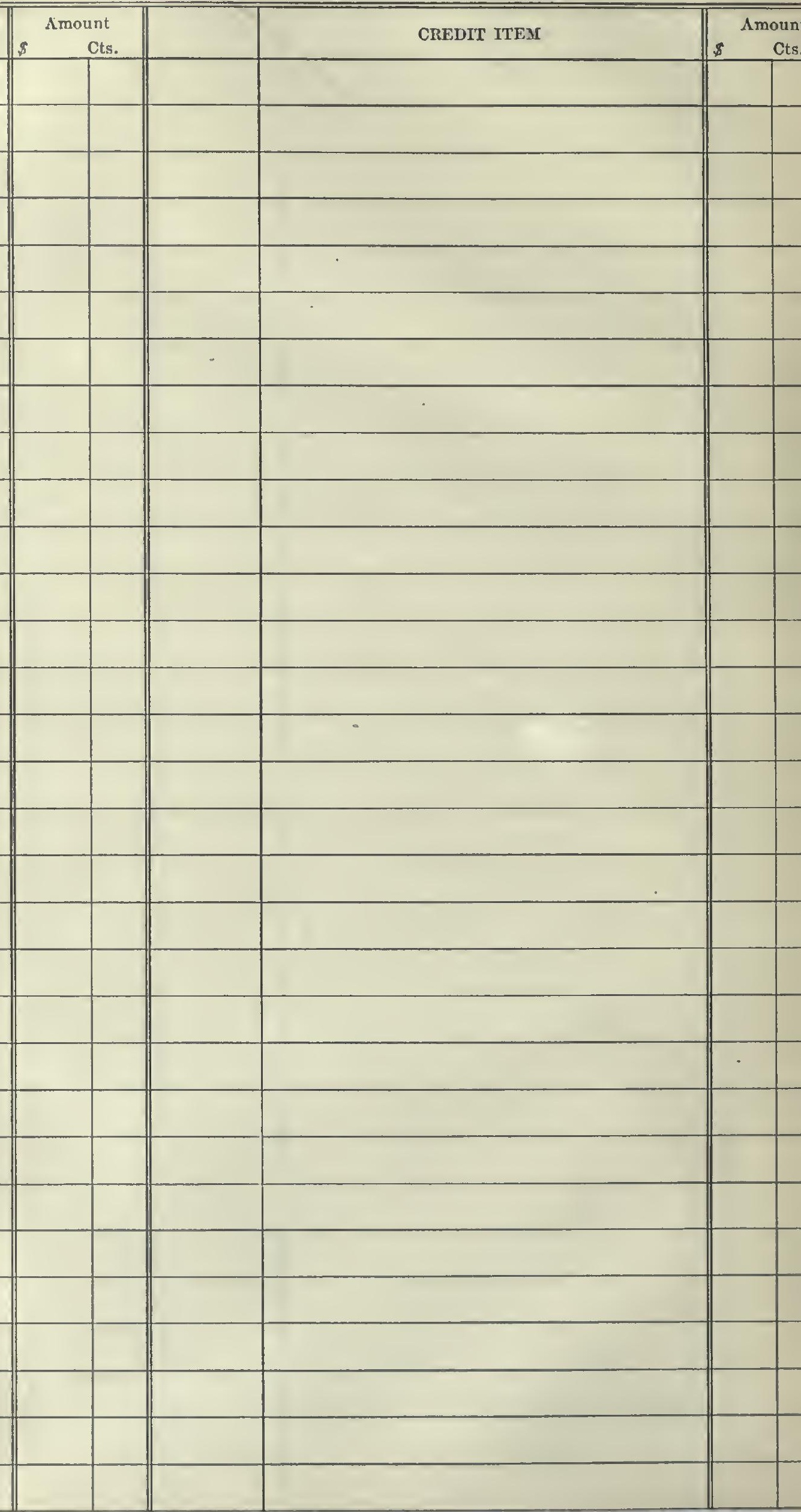


NAME

Enter below goods sold by you, cash paid by you, work done by you or your men or teams, any article of value for which you are to be paid, notes given by you

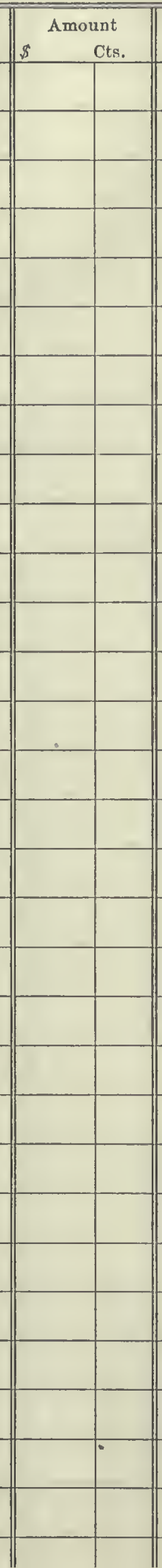

ADDRESS

Enter below cash paid to you, goods delivered to you, work done for you, any article of value for which you must pay, notes given to you

\section{Date}

DEBIT ITEM

DEBIT ITEM


NaMe

Enter below goods sold by you, cash paid by you, work done by you or your men or teams. any article of value for which you are to be paid, notes given by you
ADdREss

Enter below cash paid to you, gads delivered to you, work done for you, any article of value for which you must pay, notes given to you
CREDIT ITEM
Amouni 
Name

Enter below goods sold by you, cash paid by you, work done by you or your men or teams, any article of value for which you are to be paid, notes given by you
ADDRESS

Enter below cash paid to you, goods delivered to you, work done for you, any article of value for which you must pay, notes given to you
DEBIT ITEM

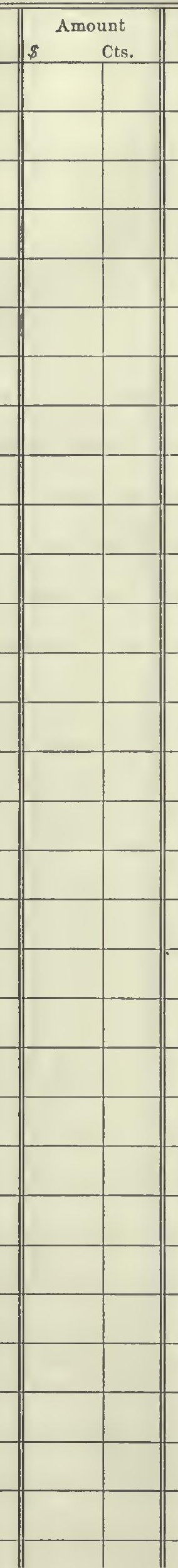

CREDIT ITEM

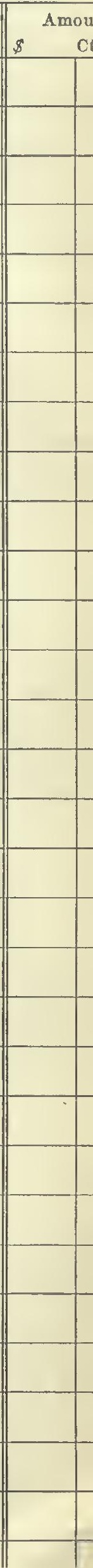


Enter below roods sold hy you, cash pald hy you, work done hy you or your men or teams, any article of value for which you are to be paid, notes given by you

Enter helow cash pald to you, goods delivered to you, work done for you, any article of value for which you must pay, notes given to you

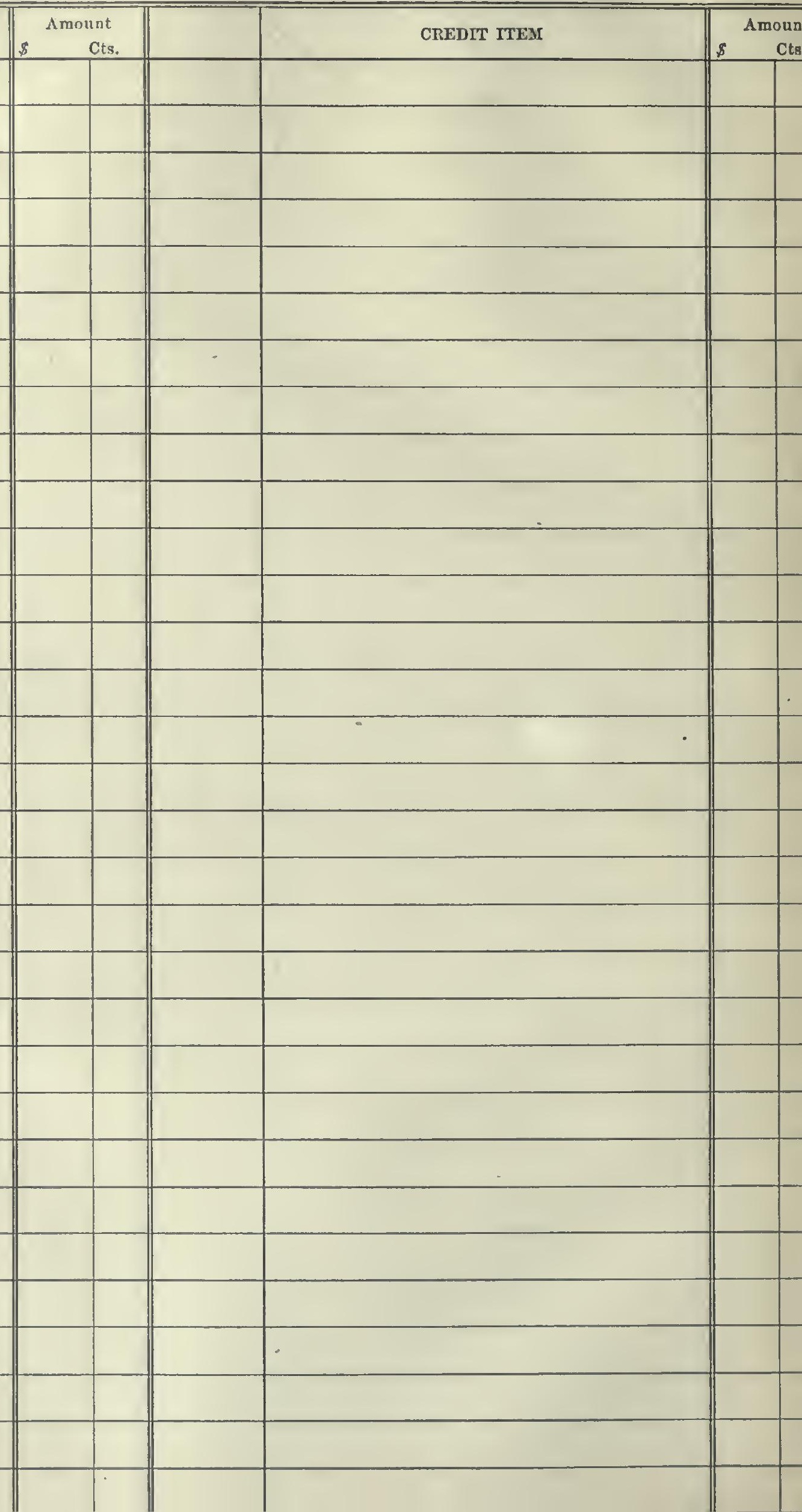


NAME

Enter below goods sold by you, cash paid by you, work done by you or your men or teams, any article of value for which you are to be paid, notes given by you
ADDRESS

Enter below cash paid to you, goods delivered to you, work done for you, any article of value for which you must pay, notes given to you

\section{Date}

DEBIT ITEN

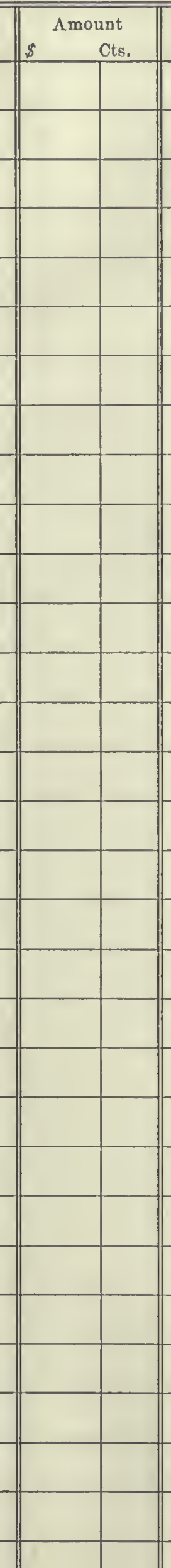

Amoun

CREDIT ITEM

$$
\$
$$


NAME

Enter below goods sold by you, cash paid by you, work done by you or your men or teams. ny article of value for which you are to be paid, notes given by you
ADDRESS

Enter below cash paid to you, goods delivered to you, work done for you, any article of value for which you must pay, notes given to you
CREDIT ITEM Cts. 
NAME

Enter below groods sold by you, eash paid by you, work done by you or your men or teams, any article of value for which you are to be paid, notes given by you
ADDRESS

Enter below cash paid to you, goods delivered to you, work done for you, any article of value for which you must pay, notes given to you

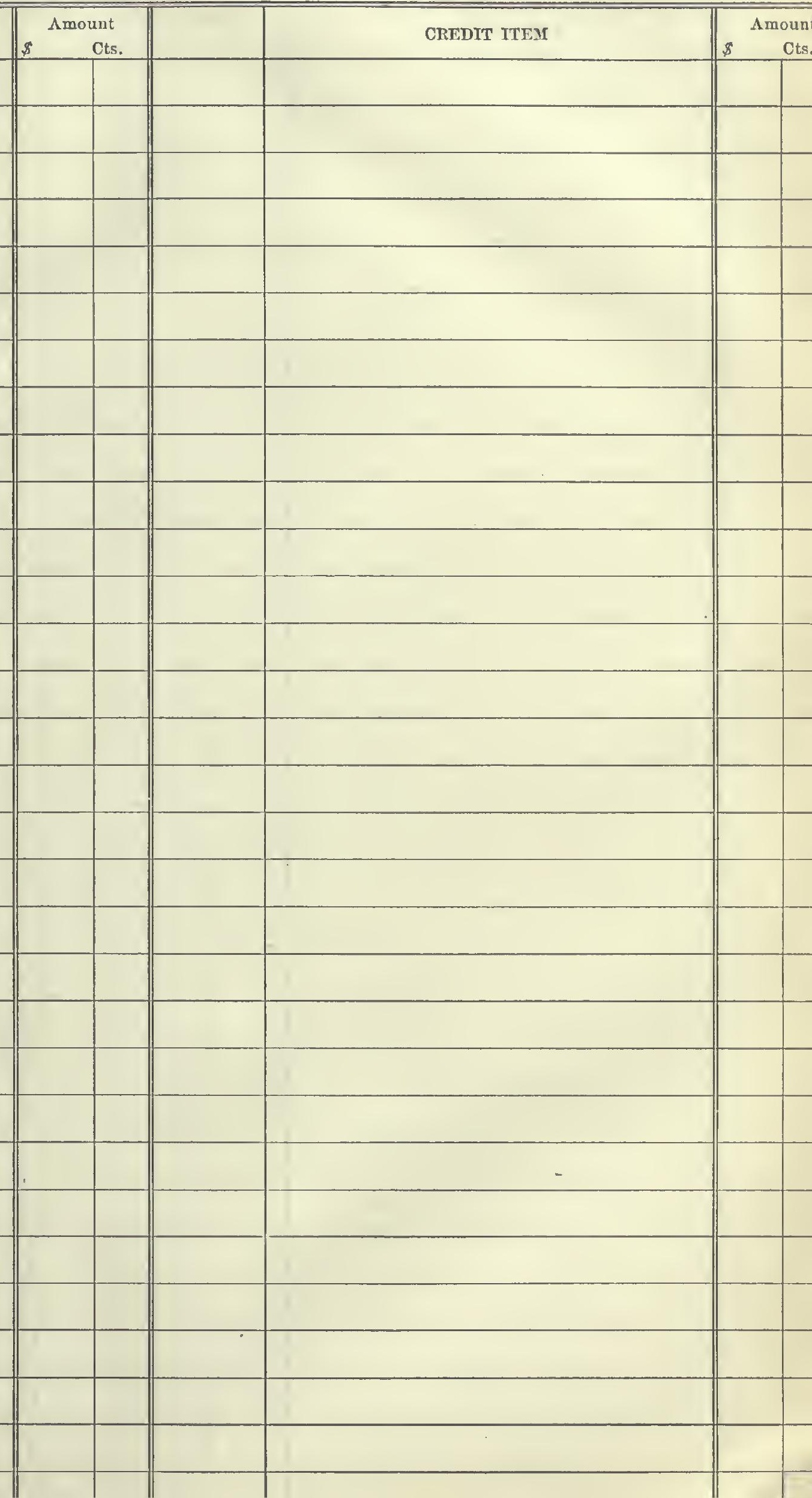


46

LEDGER ACCOUNT Enter below goods sold by you, cash paid by you, work done by you or your men or teams,
any article of value for which you are to be paid, notes given by you
ADDRESS Enter below cash paid to you, goods delivered to you, work done for you, any article of
value for which you must pay, notes given to you

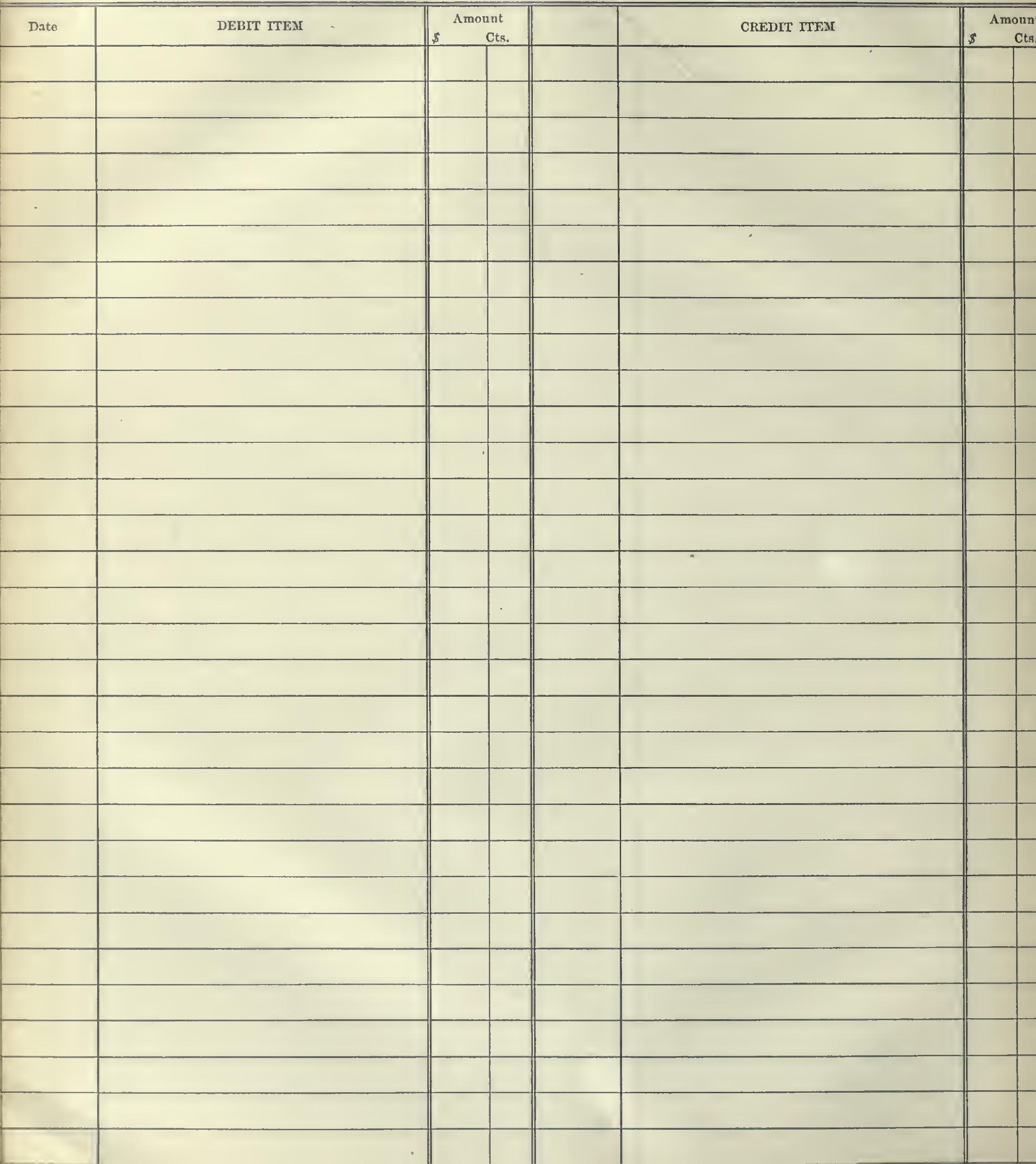


LEDGER ACCOUNT

47

NAME Enter below goods sold by you, cash paid by you, work done by you or your men or teams,
any article of value for which you are to be paid, notes given by you
ADDRESS

Enter below cash paid to you, goods delivered to you, work done for you, any article of

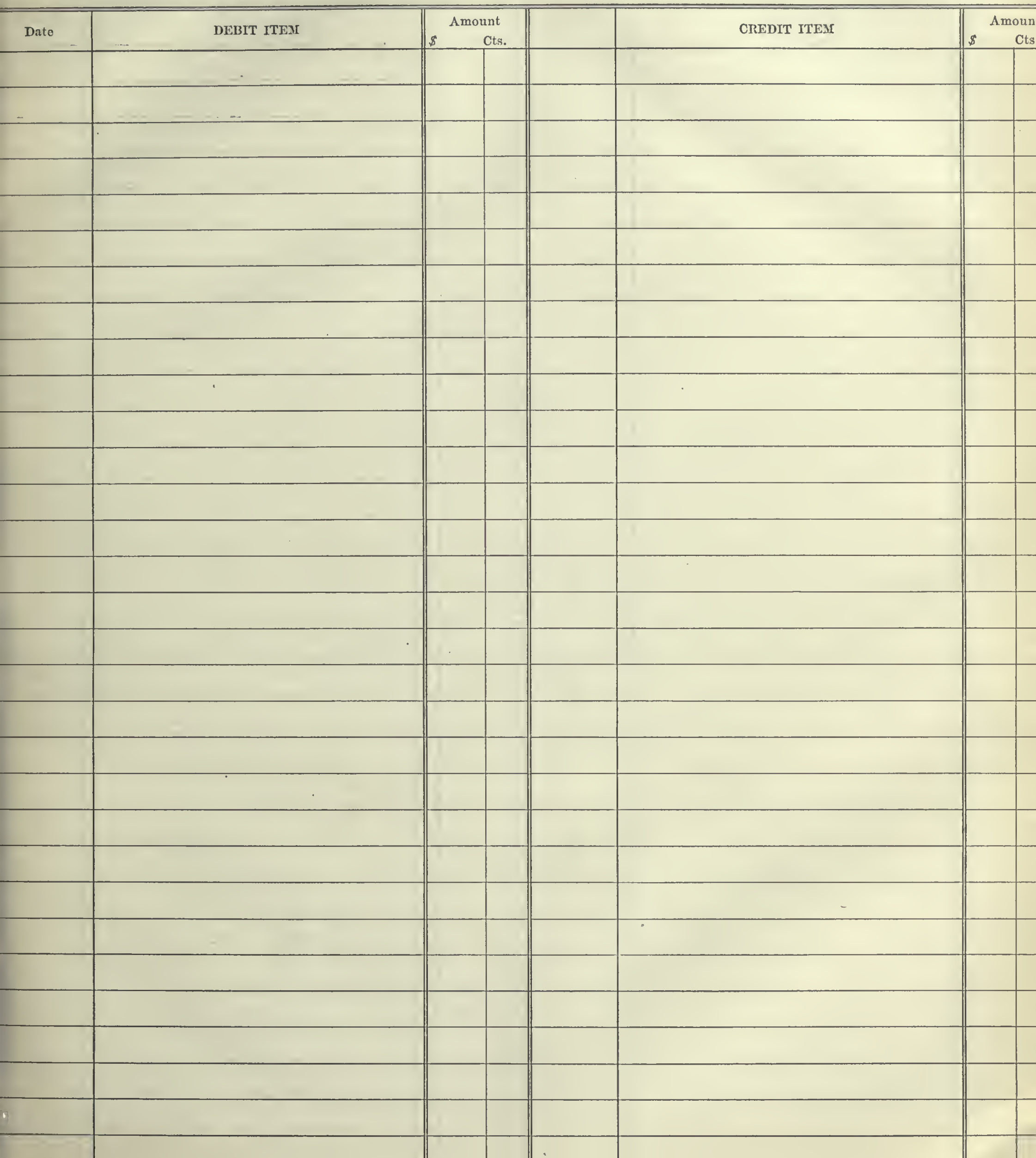


NAME

Enter below goods sold by you, cash paid by you, work done by you or your men or teams, any article of value for which you are to be paid, notes given by you
AdDREsS

Enter below cash pald to you, goods delivered to you, work done for you, any article of value for which you must pay, notes given to you
Date
DEBIT ITEN

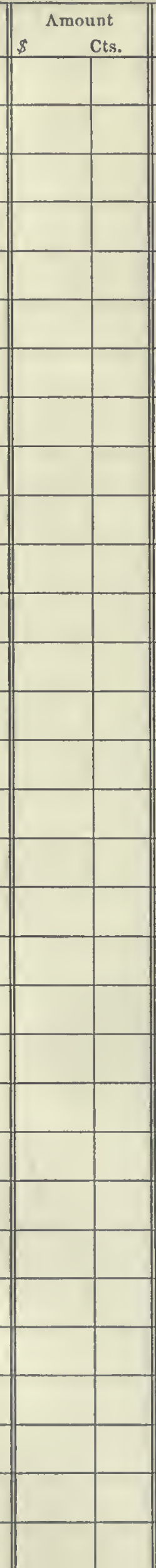

CREDTT 


\section{LEDGER ACCOUNT}

NAME

Fiter below goods sold by you, eash paid by you, work done by you or your men or teams, any article of value for which jou are to be puid, notes given by you
DEBIT ITEN

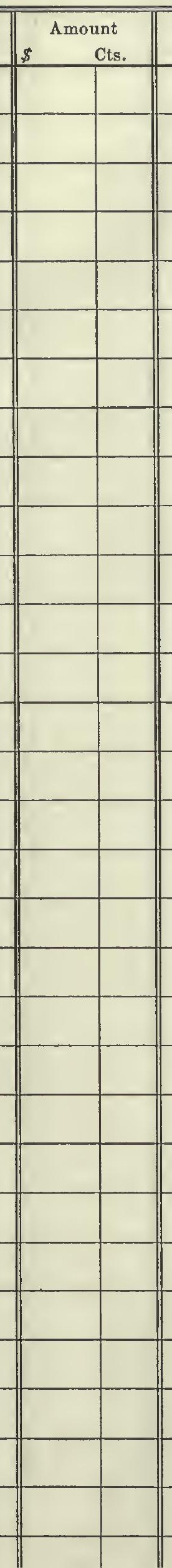

ADDRESS

Enter below cash paid to you, goods delivered to you, work done for you, any article of value for which you must pay, notes given to you
Amount

CREDIT ITEM 
NAME_

Enter below goods sold by you, cash paid by you, work done by you or your men or teams, any article of value for which you are to be paid, notes given by you

Dato

DEBIT ITEJI

\section{ADDRESS}

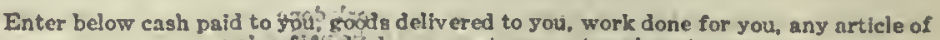
value for whilch you must pay, notes given to you

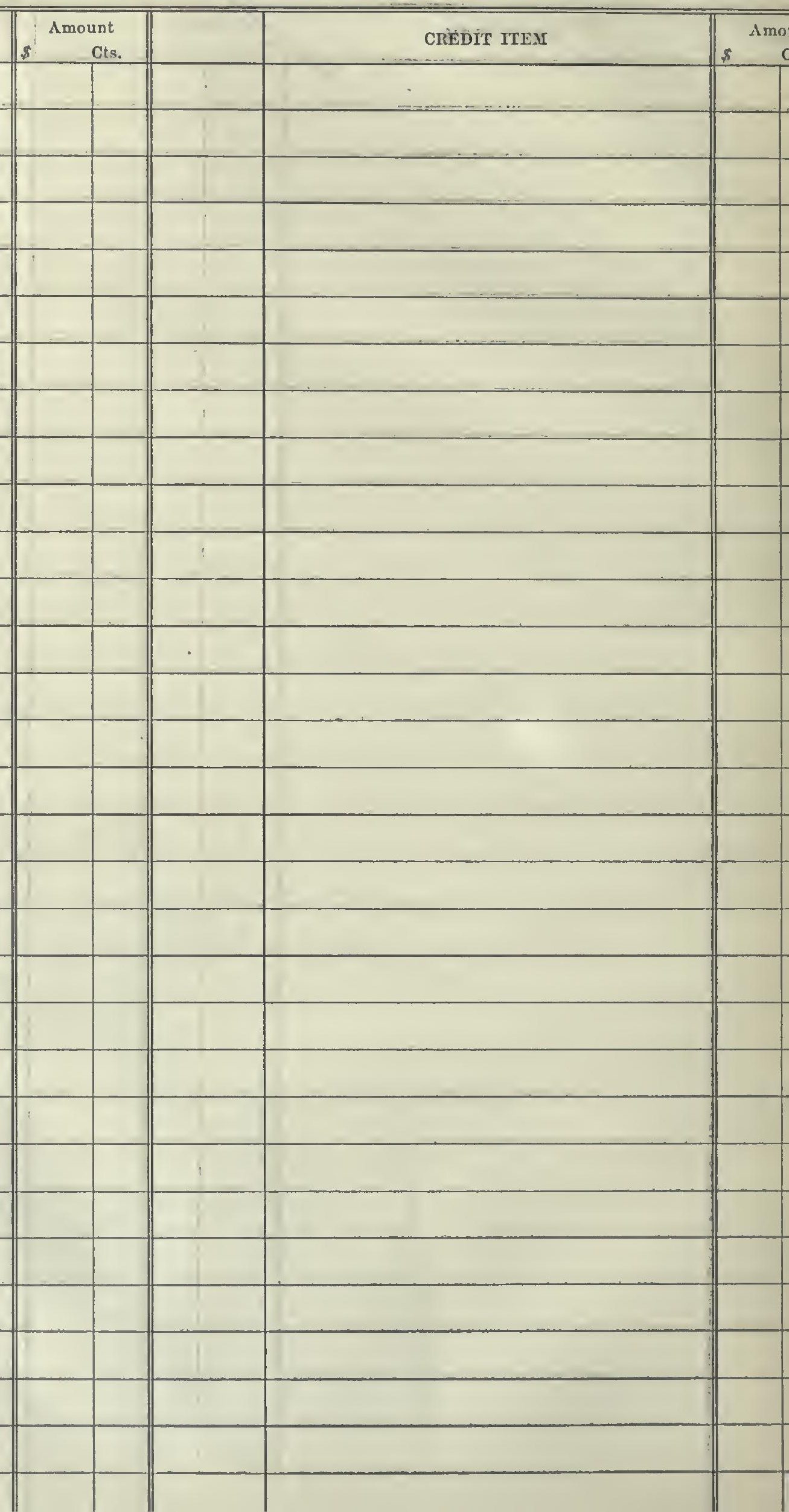




\section{LEDGER ACCOUNT}

5

NAME

Enter below goods sold by you, cash paid by you, work done by you or your men or tearas, any articlo of value for which you are to be paid, notes given by you

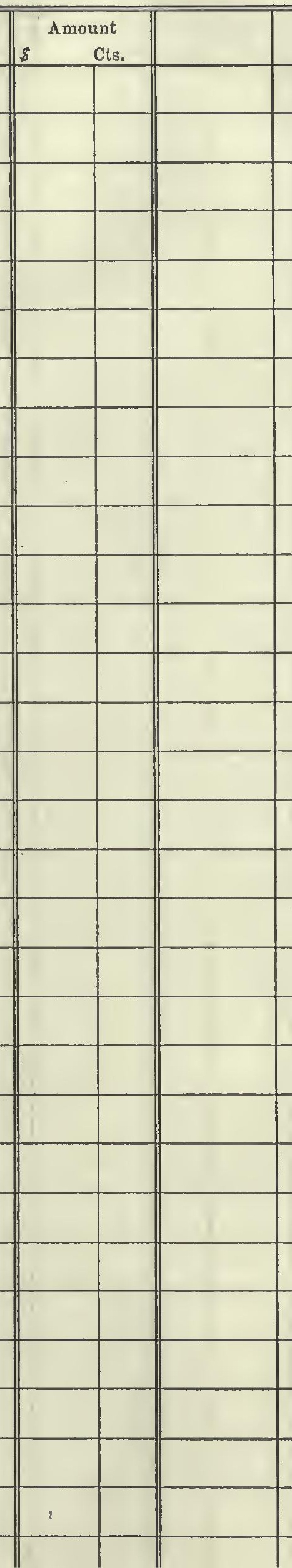

ADDRESS

Enter below cash paid to you, goods delivered to you, work done for you, any article of value for which you must pay, notes given to you

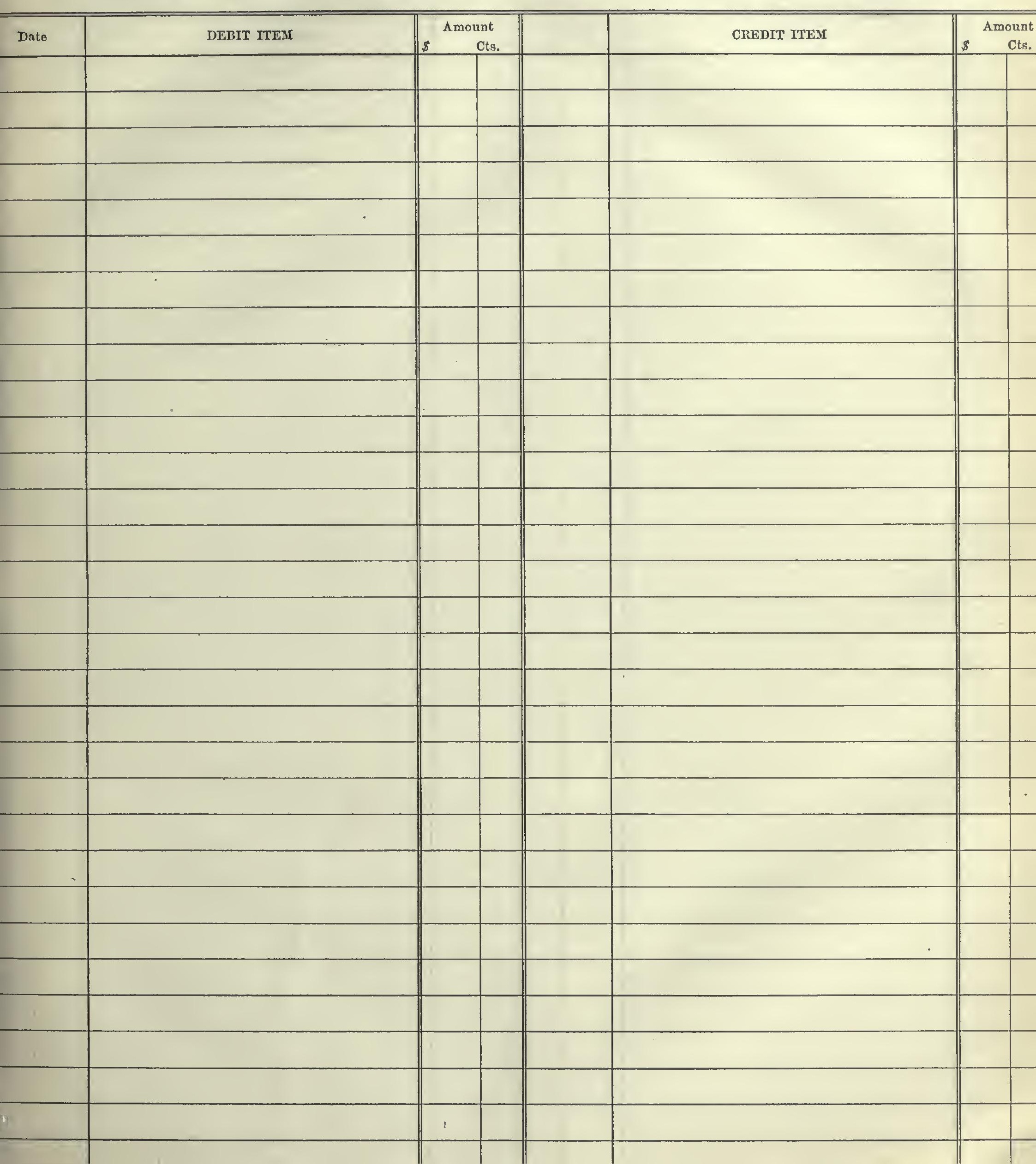


NAME

Enter below goods sold by you, cash paid by you, work done by you or your men or teams, any article of value for which you are to be paid, notes given by you

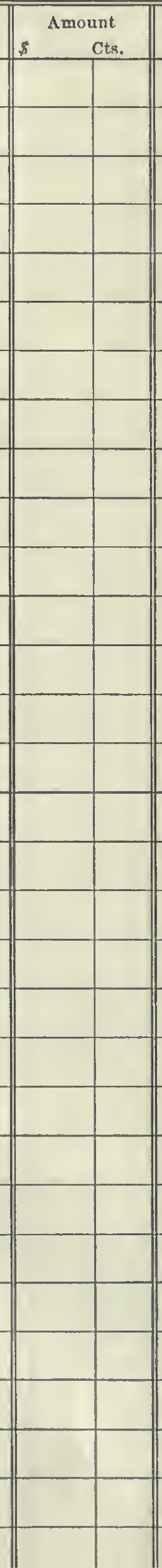

ADDRESS

Enter below cash paid to foo, gofds delivered to you, work done for you, any article of value for wisich you must pay, notes given to you 
LEDGER ACCOUNT

NAME

Enter below rods sold by you, each paid by you, work done by you or your men or teams,

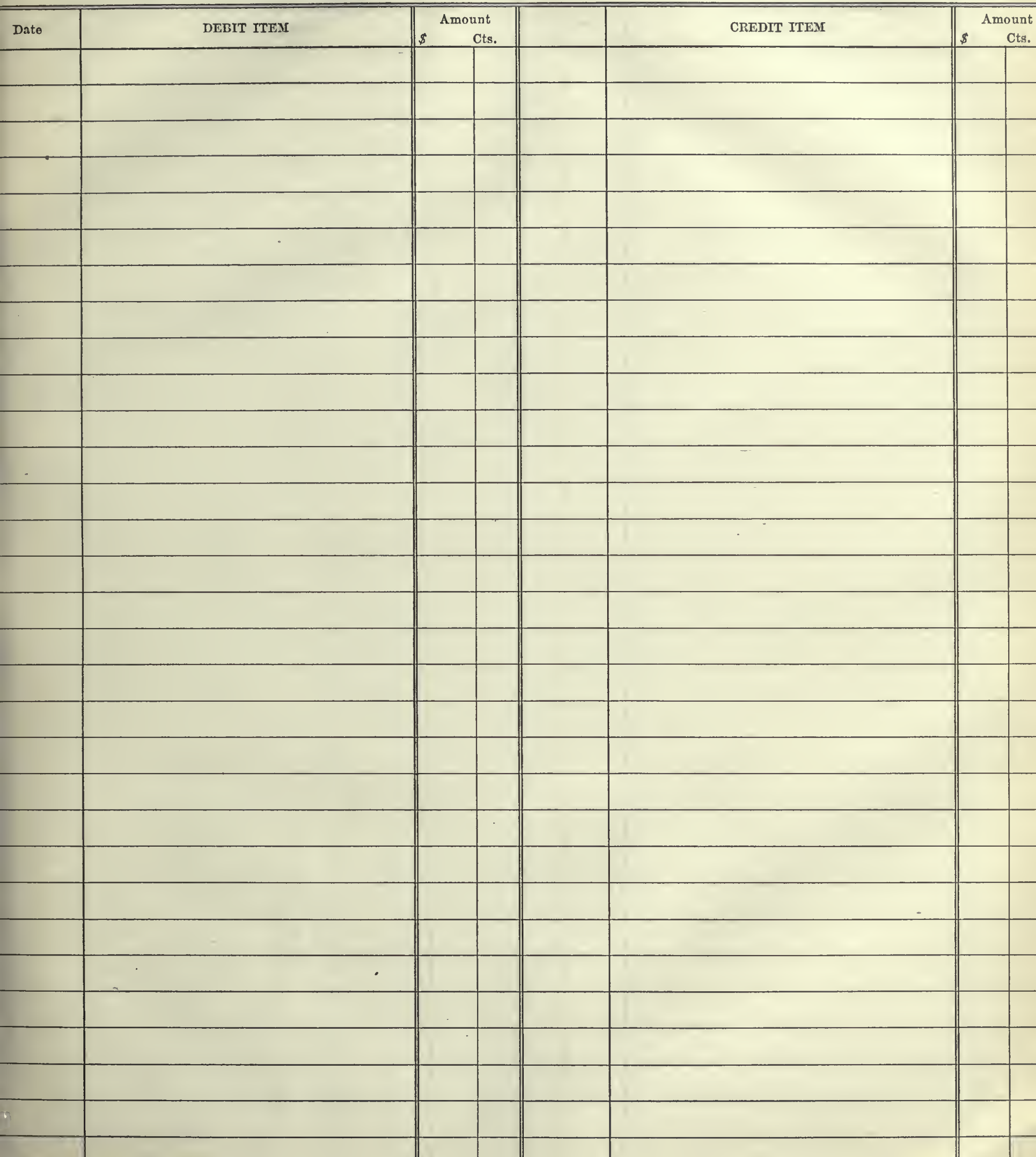


NAME

Enter below goods sold by you, cash paid by you, work done by you or yoür men or teams, any article of value for which you are to be paid, notes given by you
ADDRESS

Enter below cash paid to yod, theds delivered to you, work done for you, any article of - valuektorwhich you must pay, notes given to you

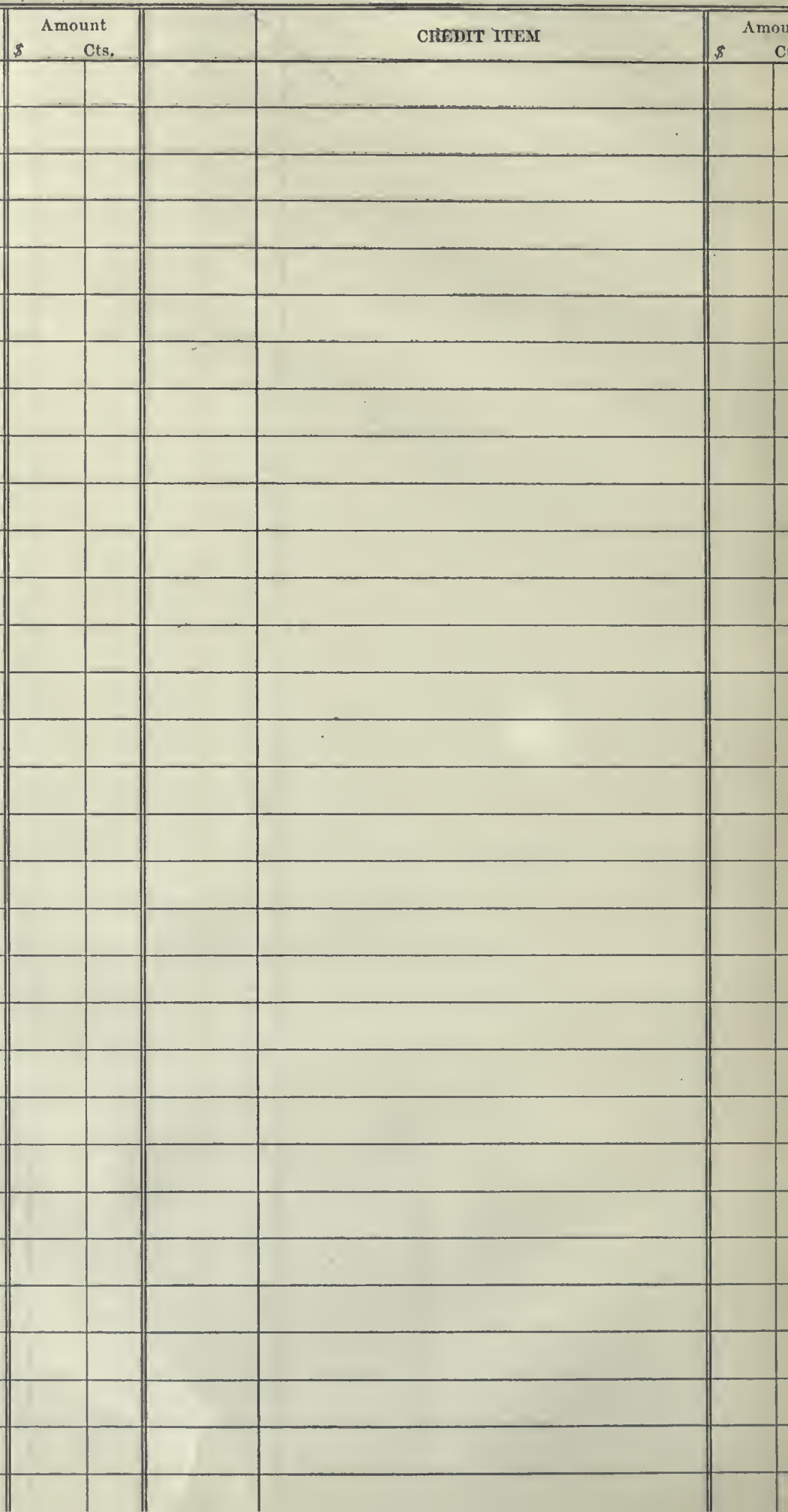


LEDGER ACCOUNT

NAME Enter below goods sold by you, cash paid by you, work done by you or your men or teams,
any article of value for which you are to be paid, notes given by you
ADDRESS

Enter below cash paid to you, goods delivered to you, work done for you, any article of value for which you must pay, notes given to you

55

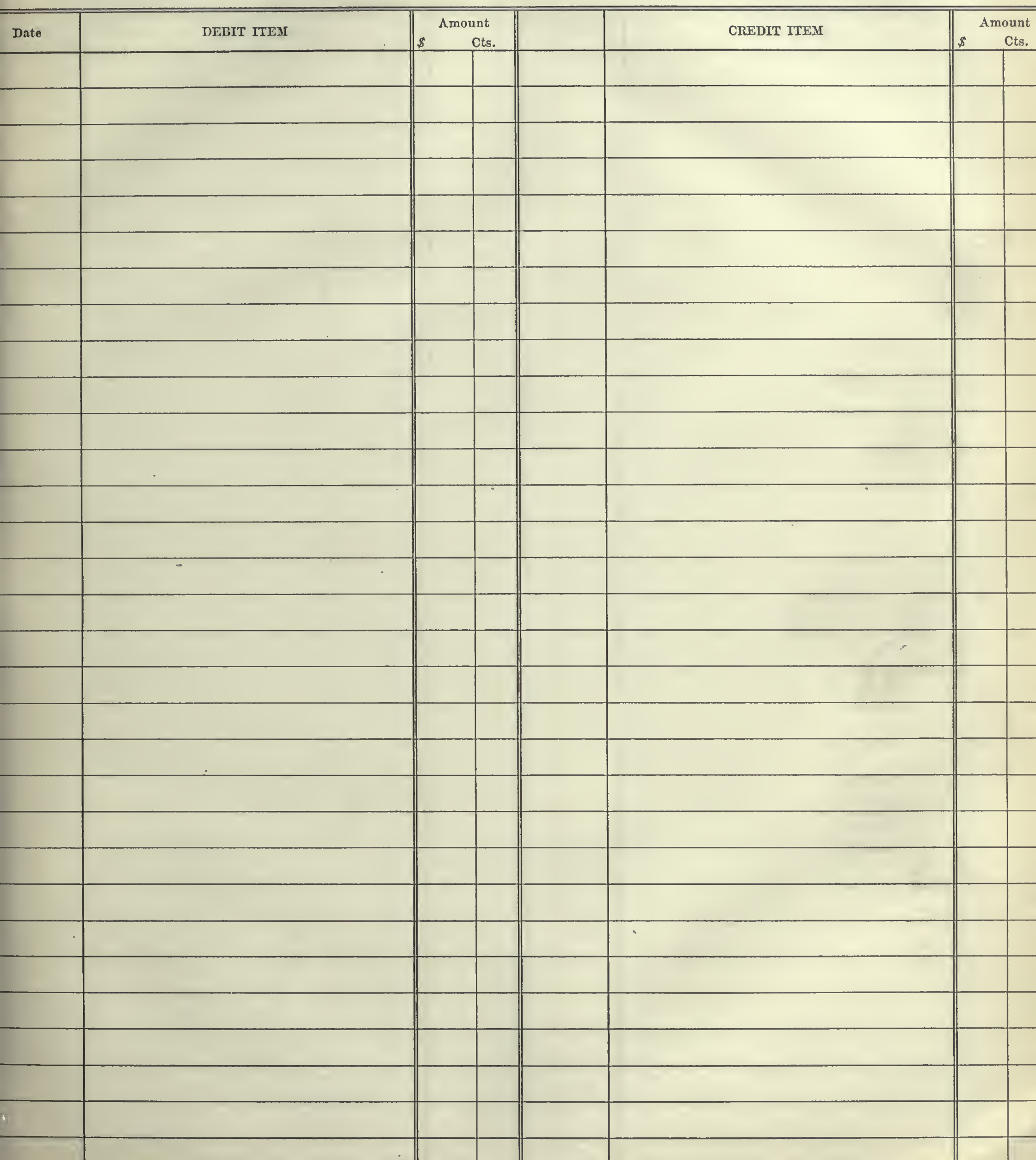




\section{LEDGER .ACCOUNT}

NAME

Enter below goods sold by you, eash paid by you, work done by you or your men or teams, any article of value for which you are to be paid, notes given by you
DEBIT ITEM
ADDRESS

Enter below cash paid to you, goods delivered to you, work done for you, any article of value for which you must pay, notes given to you

CREDIT ITEN

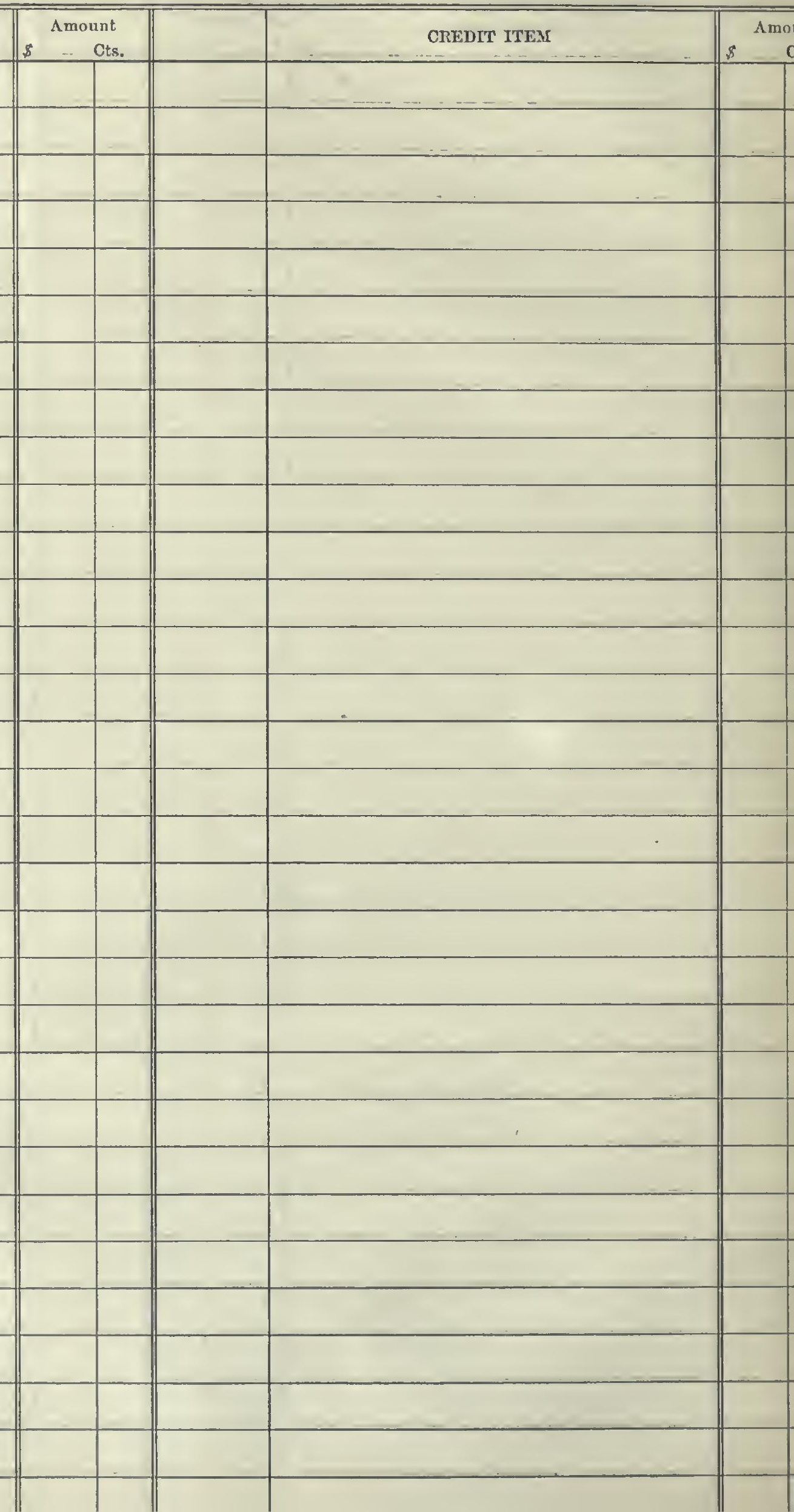




\section{LEDGER ACCOUNT}

NAME

Enter below roods sold by you, cash paid by you, work done by you or your men or teams, any article of value for which you are to be daid, notes given by you

\section{Date}

ADDRESS

Enter below cash paid to you, goods delivered to you, work done for you, any article of value for which you must pay, notes given to you

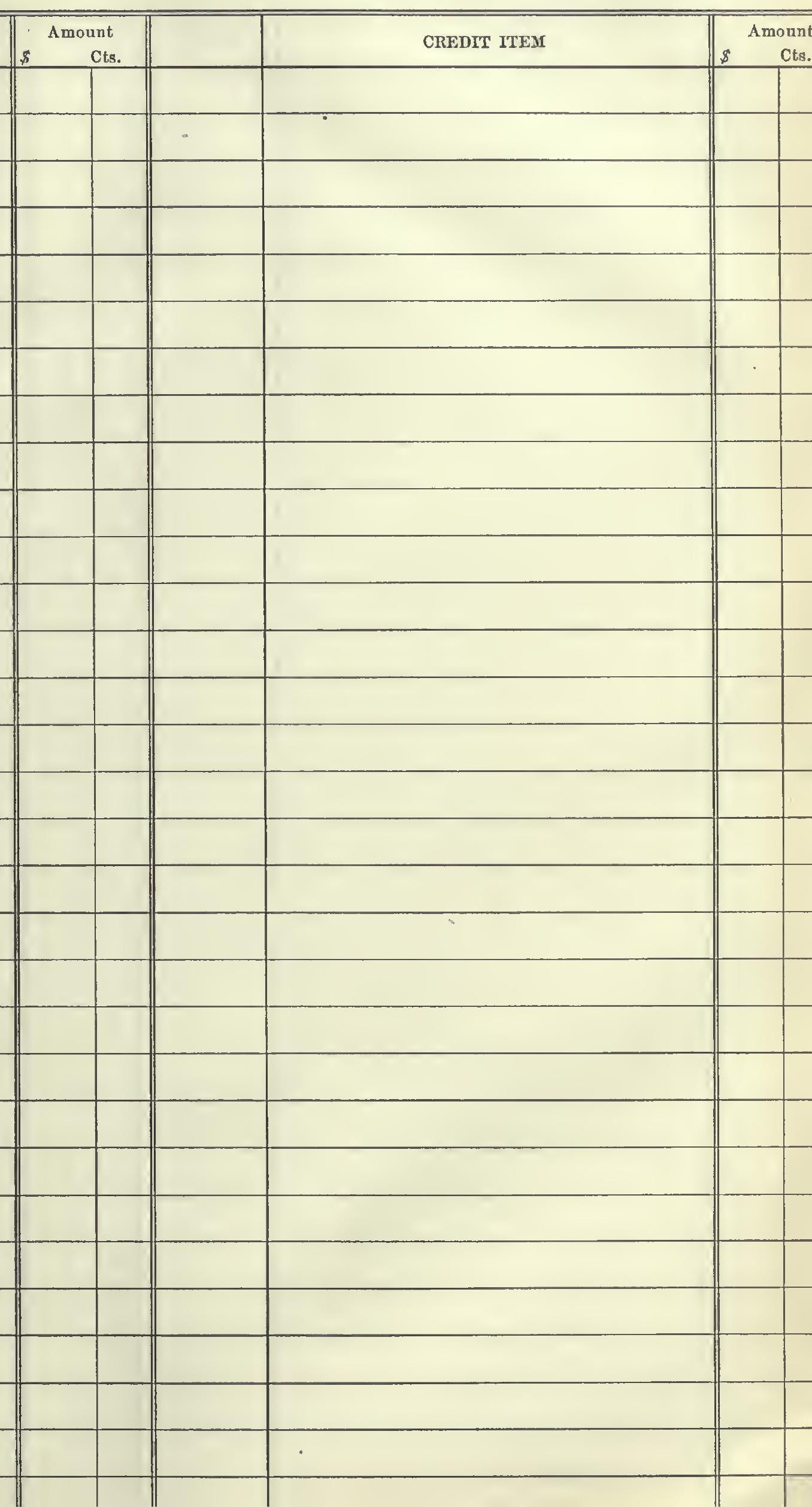




\section{LEDGER AACCOUNT}

NAME

Enter below goods sold by you, cash paid by you, work done by you or your men or teams, any article of value for which you are to be paid, notes given by you
ADDRESS

Enter below cash pald to you, gonds delivered to you, work done for you, any article of value for which you must pay, notes given to you
DEBIT ITEM

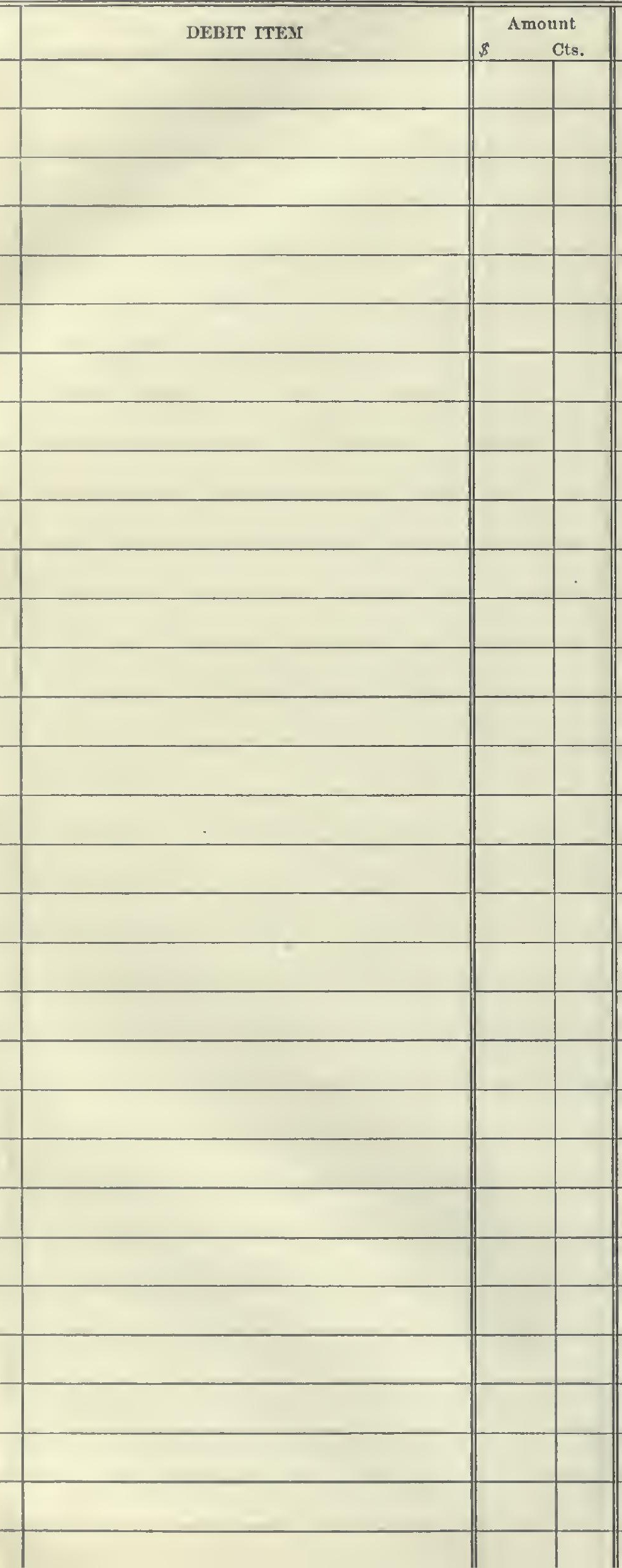

Date
CREDIT ITEII 
NAME

Enter below roods sold by you, eash paid by you, work done by you or your men or teams, any article of value for which you are to be daid, notes given by gou

\section{A DDRESS}

Enter below cash paid to you, goods delivered to you, work done for you, any article of valuo for which you must pay, notes given to you

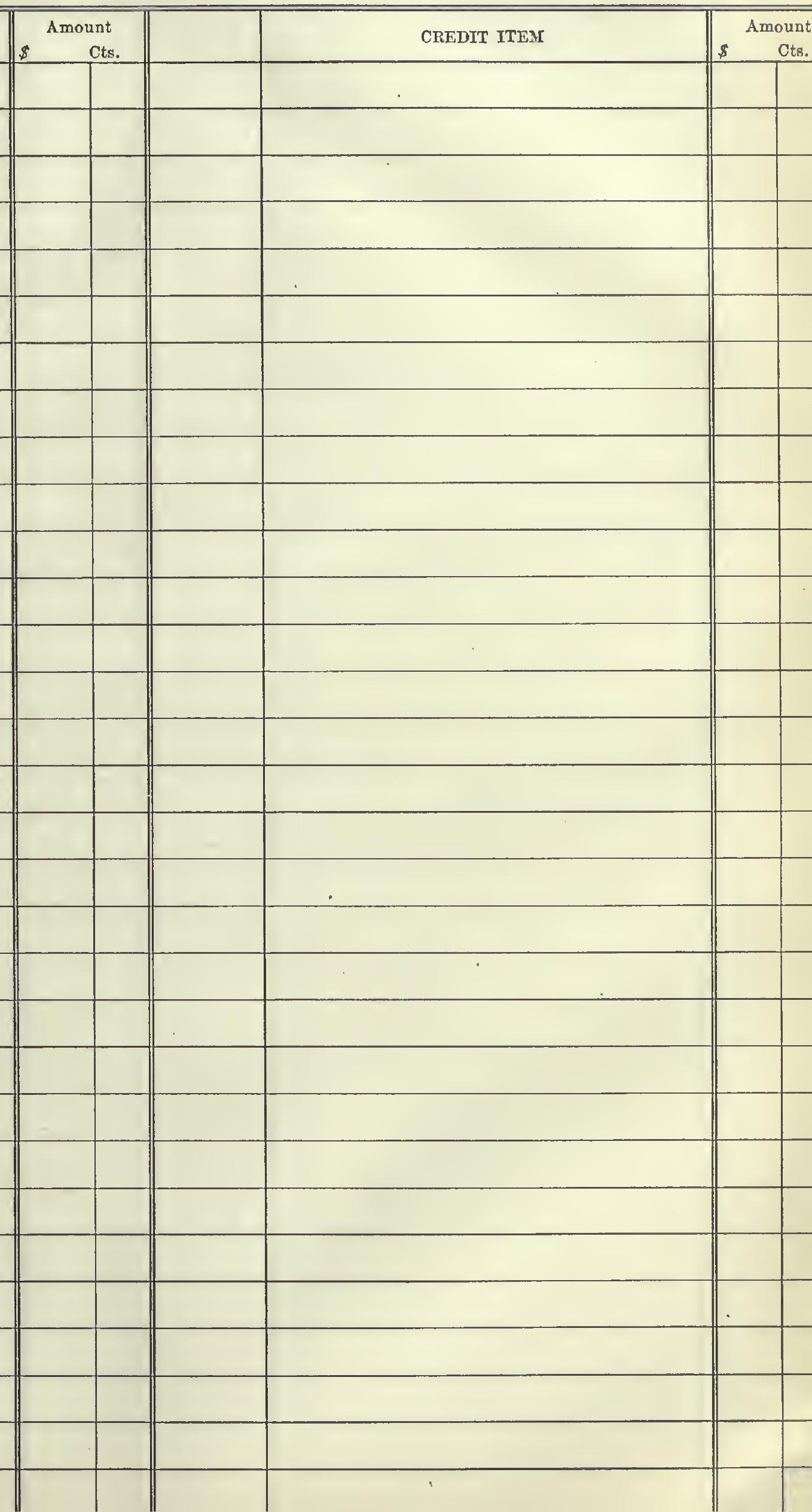




\section{LEDGER •ACCOUNT}

NAME

Enter below goods sold by you, cash paid by you, work done by you or your men or teams, any article of value for which you are to be paid, notes given by you

DEBIT ITEX
ADDRESS

Enter below cash paid to you, goods delivered to you, work done for you, any article of - value for which you must pay, notes given to you

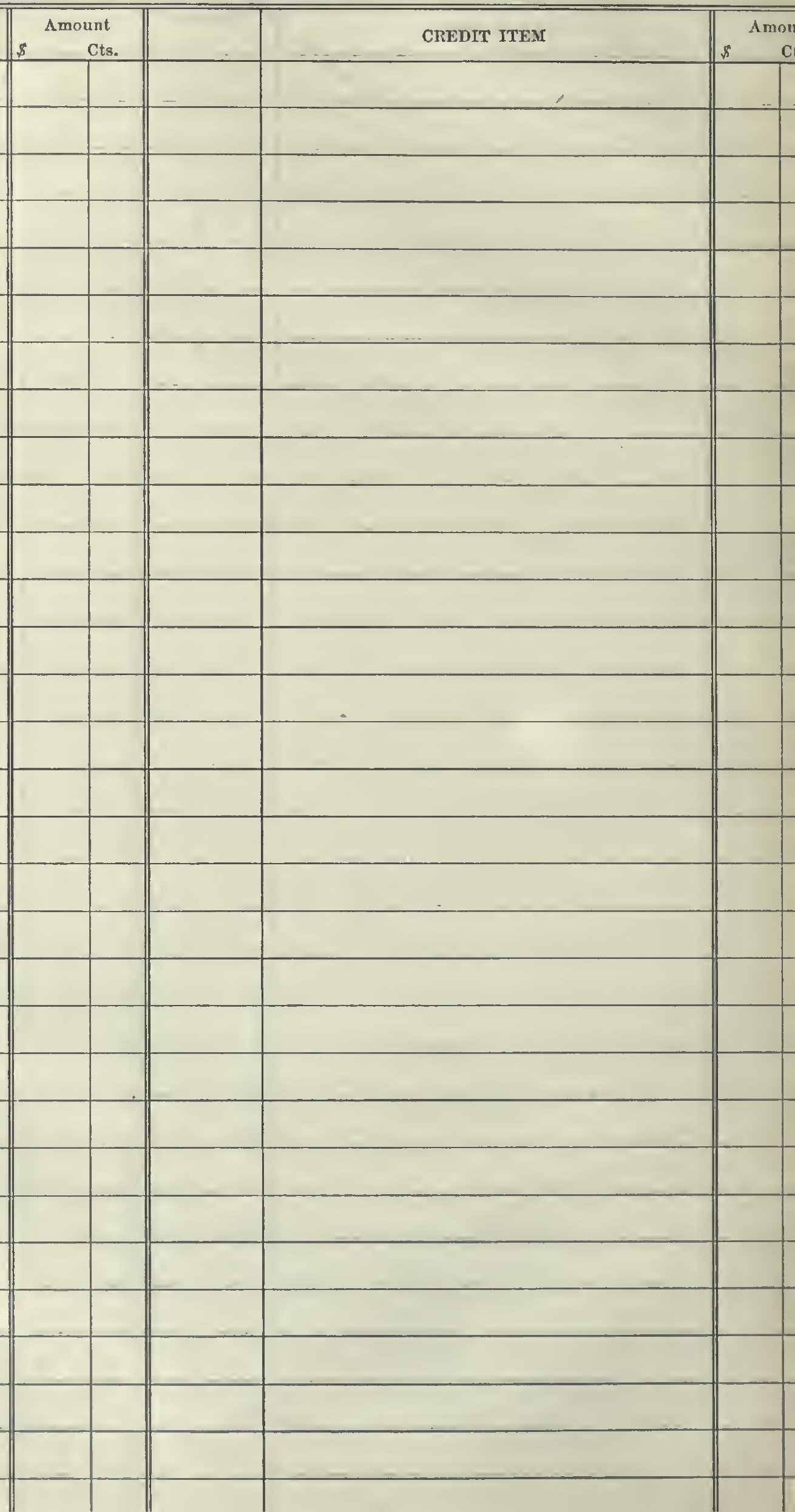


NAME

Enter below goods sold by you, cash paid by you, work done by you or your men or teams, any article of value for which you are to be paid, notes given by you

DEBIT ITEM

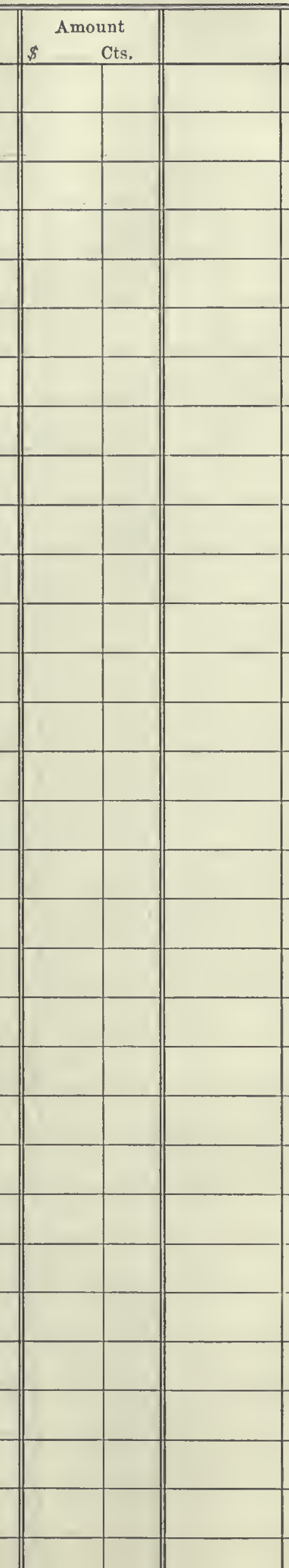

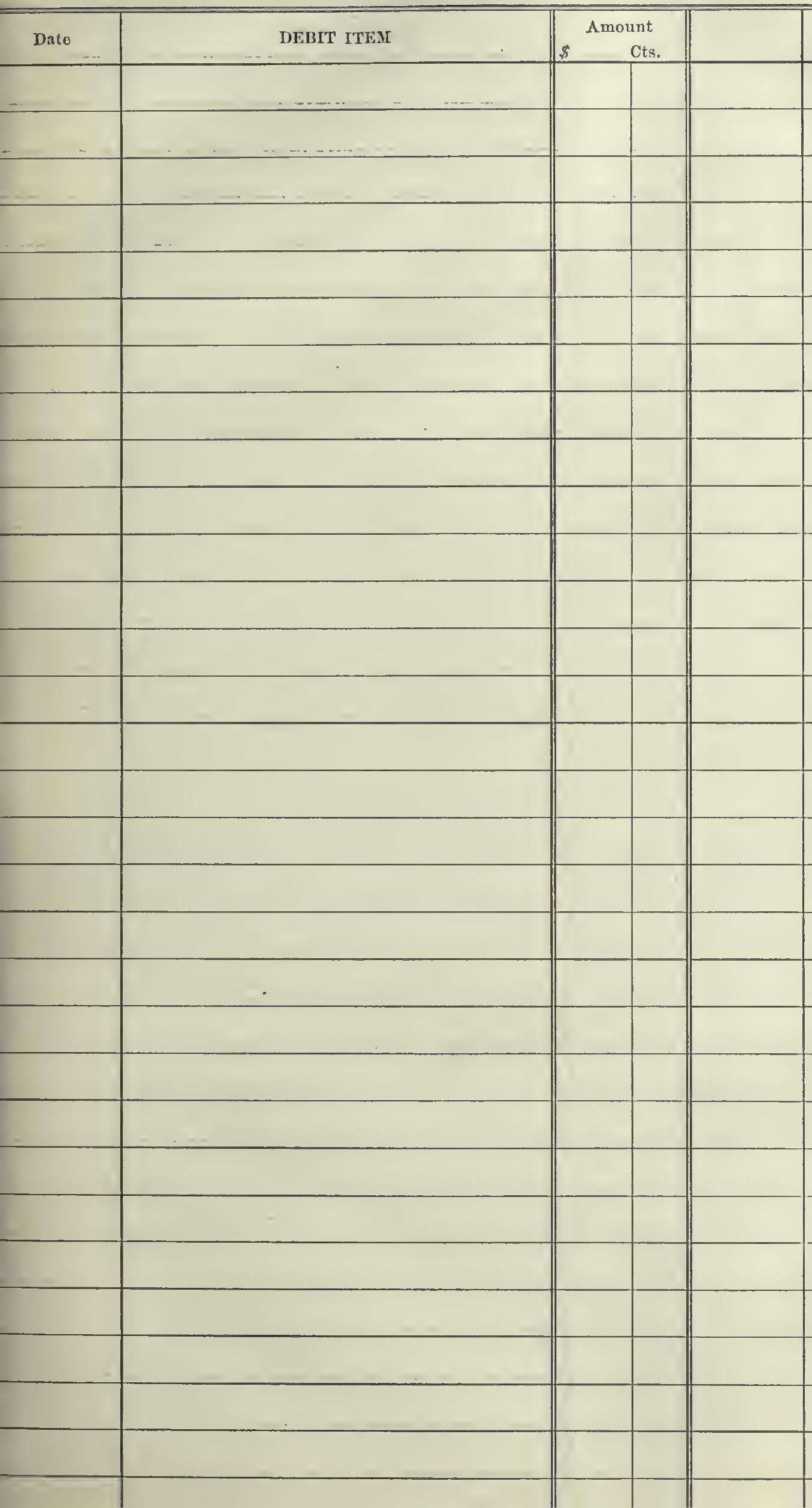

ADDRESS

Enter bclow cash paid to you, goods delivered to you, work done for you, any article of value for which you must pay, notes given to you
CREDIT ITEM
Amoun

$\$ \quad$ Cts


NAME

Enter below roods sold by you, cash paid by you, work done by you or your men or teams. any article of value for which you are to be paid, notes given by you
ADDRESS

Enter below cash pald to you, goods delivered to you, work done for you, any article of value for wbich you must pay, notes given to you 
NAME

Enter below grods sold by you, cash paid by you, work done by you or your men or teams. any article of value for wbich you are to be paid, notes given by you
ADDRESS

Enter below cash paid to you, goods delivered to you, work done for you, any article of value for which you must pay, notes given to you 
NAME

Enter below goods sold by you, cash paid by you, work done by you or your men or teams, any article of value for which you are to be paid, notes given by you
ADDRESS

Enter below cash paid to you, goods delivered to you, work done for you, any article of value for which you must pay, notes given to you

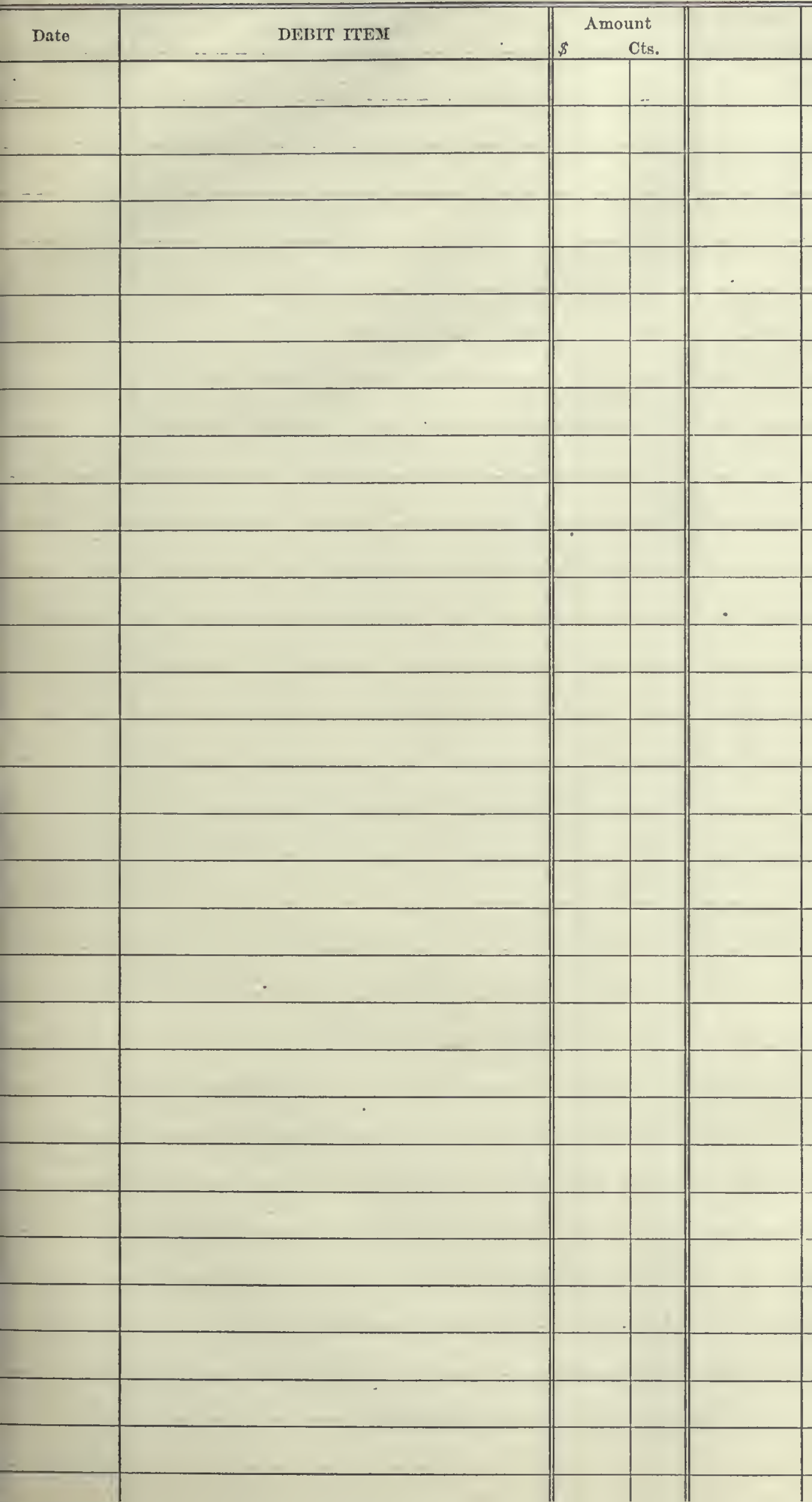


NAME

Enter below soods sold by you, cash paid by you, work done by you or your men or teams, any article of value for which you are to be paid, notes siven by you
ADDRESS

Enter below cash paid to you, goods delivered to you, work done for you, any article of value for which you must pay, notes given to you
DEBIT ITEN

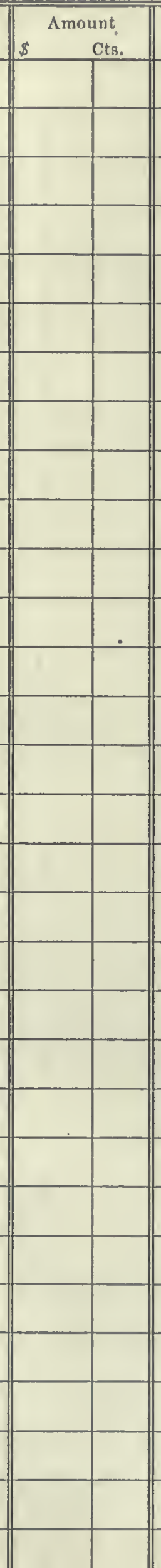

CREDIT ITEY
Amoun

Cts. 
NaME:

Enter below goods sold by you, cash paid by you, work done by you or your men or teams, any article of value for which you are to be paid, notes given by you
ADDRESS

Enter below cash paid to you, goods delivered to you, work done for you, any article of value for which you must pay, notes given to you

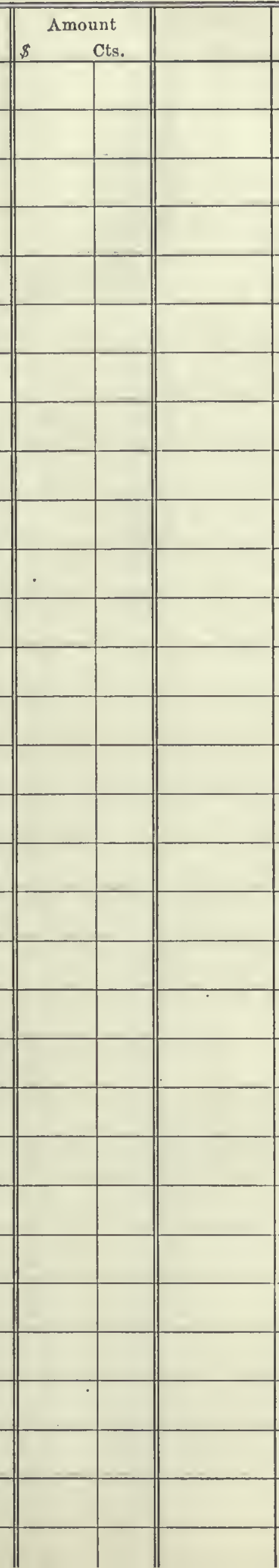

CREDIT ITEM

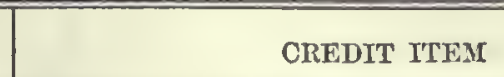

DEBIT ITEM
Amount $\$$ Cts. 
Name

Enter below goods sold by you, cash paid by you, work done by you or your men or teams, any article of value for which you are to be paid, notes given by you
ADDRESS

Enter below cash paid to you, goods delivered to you, work done for you, any article of value for which you must pay, notes given to you
DEBIT ITEMI

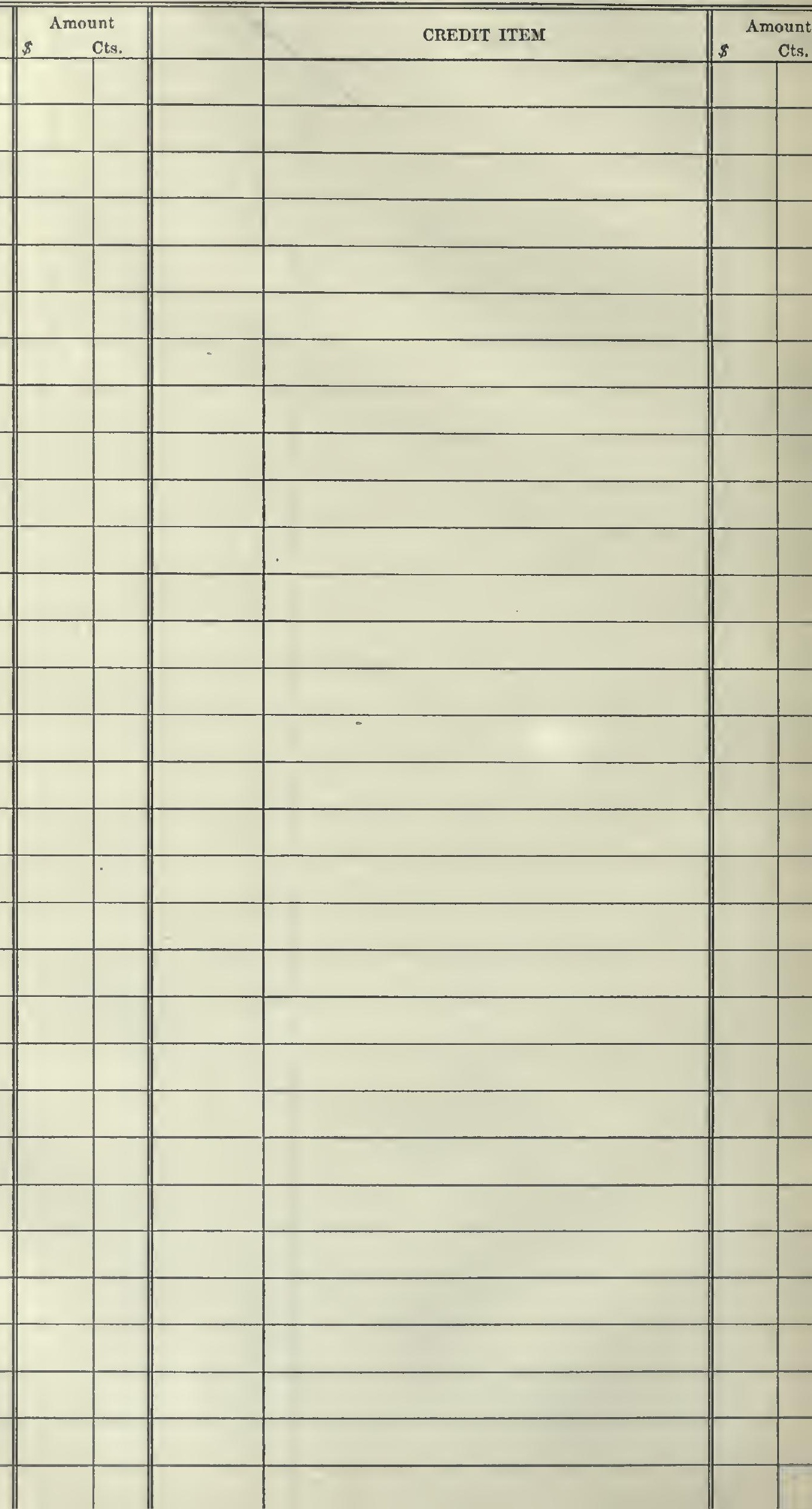




\section{LEDGER ACCOUNT}

NAME

Enter below goods sold by you, cash paid by you, work done by you or your men or teams, any article of value for which you are to be paid, notes given by you
ADDRESS

Enter below cash paid to you, goods delivered to you, work done for you, any article of value for which you must pay, notes given to you

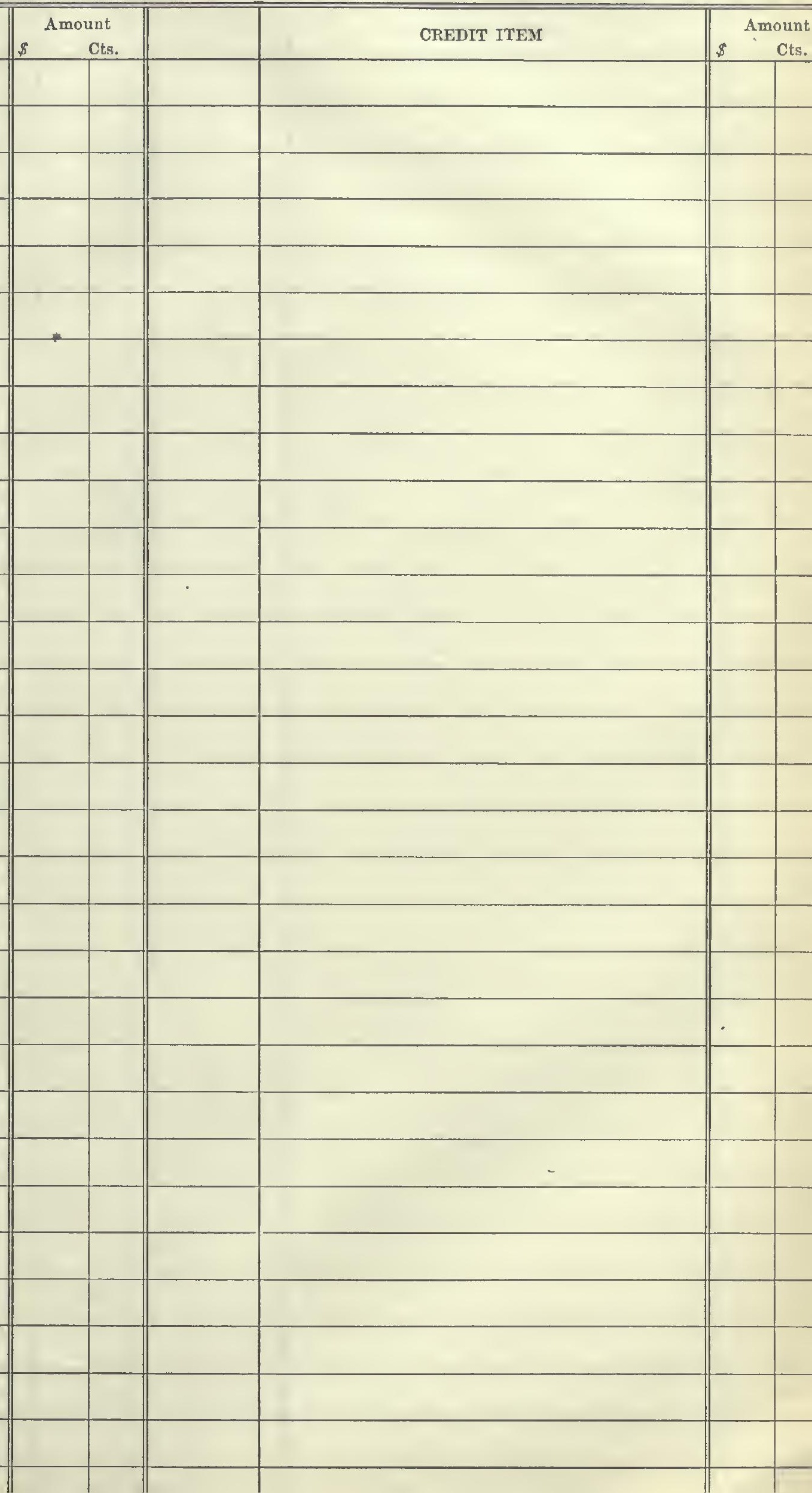




\section{LEDGER ACCOUNT}

NAME

Enter below goods sold by you, cash naid by you, work done by you or your men or teams, any article of value for which you are to be paid, notes given by you
ADDRESS

Enter below cash paid to you, goods delivered to you, work done for you, any article of value for which you must pay, notes given to you

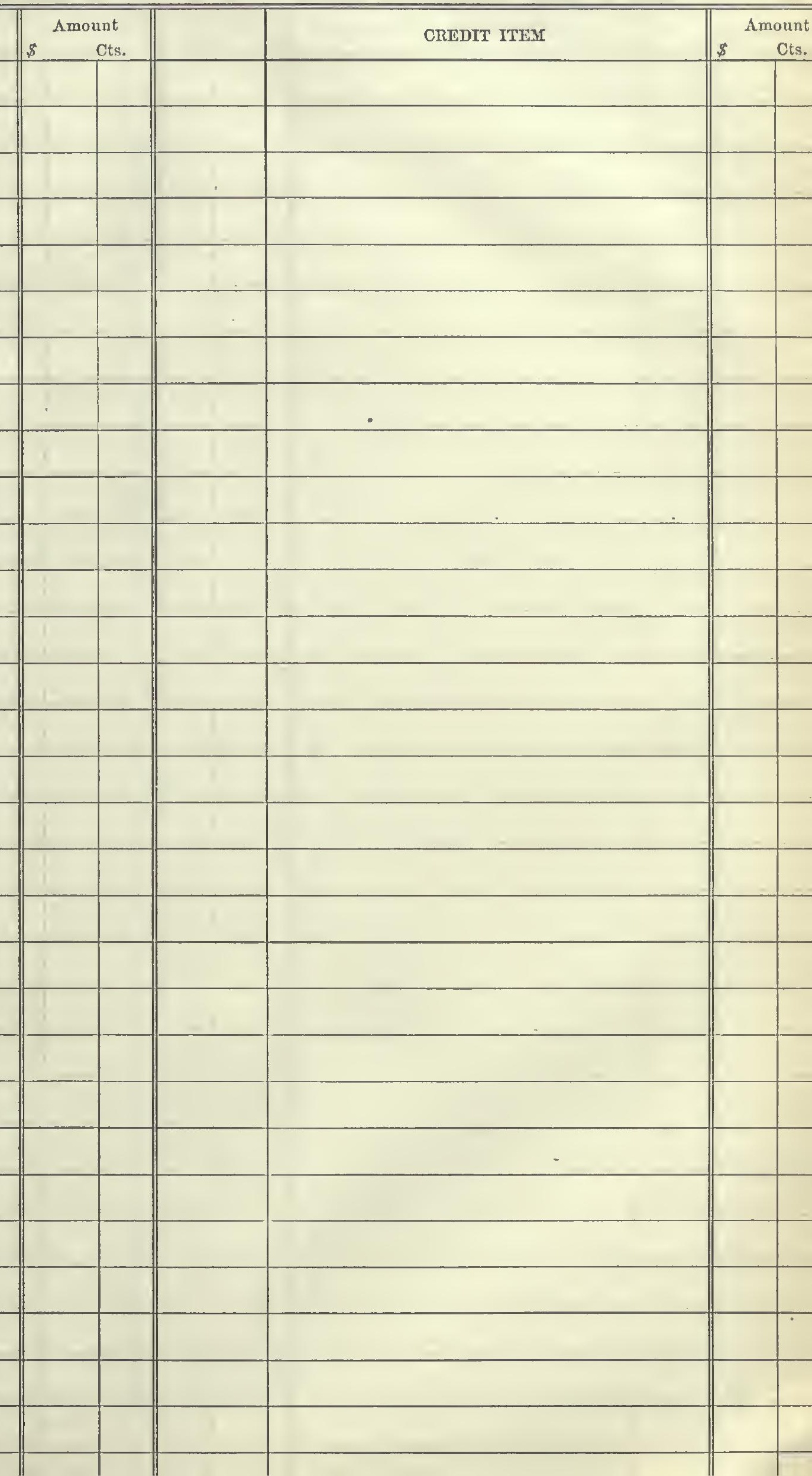


Nane

Enter below goods sold by you, cash paid by you, work done by you or your men or teams. any article of value for which you are to be paid, notes given by you
ADDRESS

Enter below cash paid to you, goods delivered to you, work done for you, any article of value for which you must pay, notes given to you

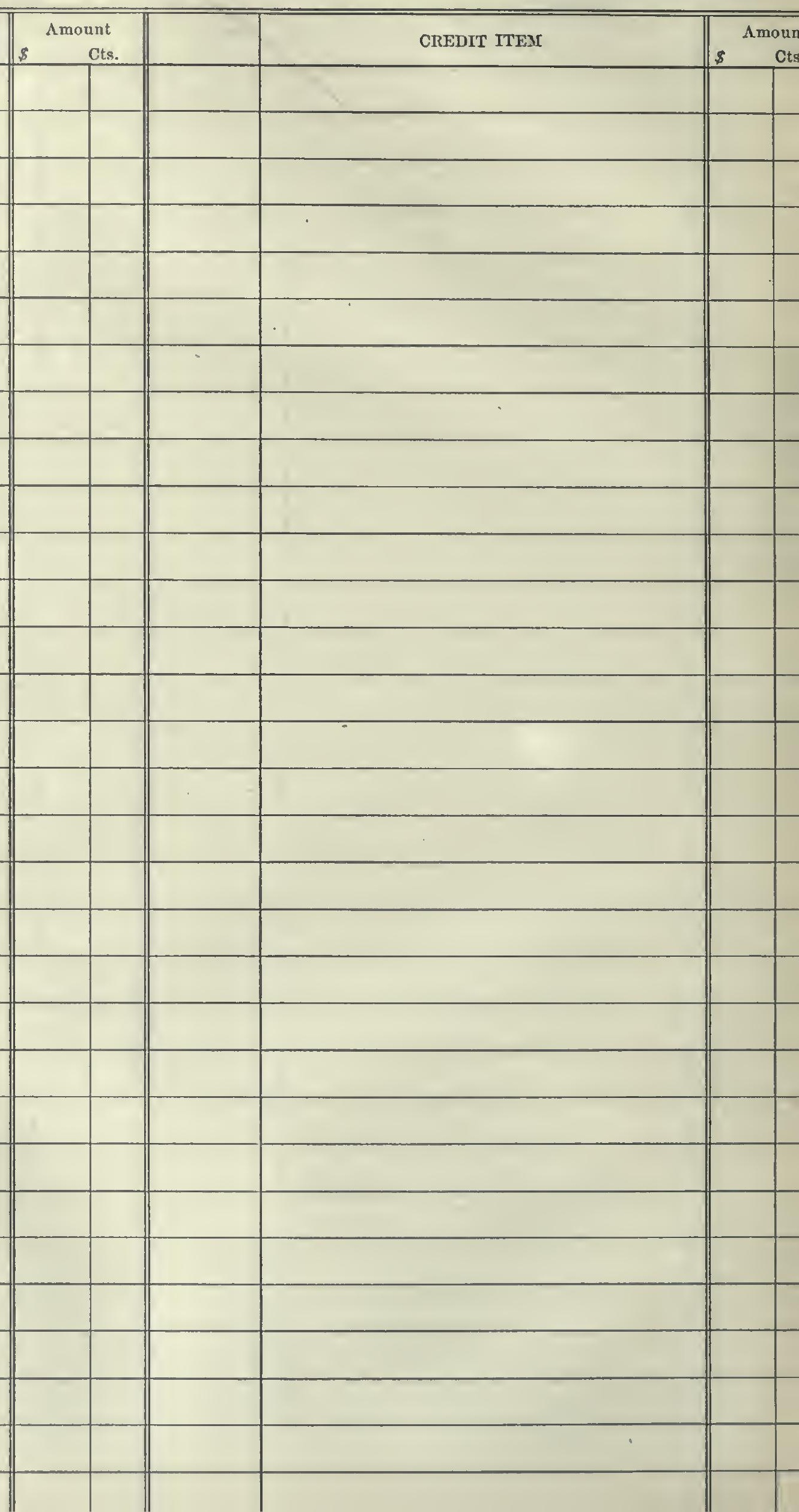


Enter on this page every amount of eash paid by you, writing name of person and what paid for. Begin account by entering amount on hand. 
Cash received by you in

Enter on this page every amount of cash paid by you, writing name of person and what paid for. Begin account by entering amount on hand. 
Enter on this page every amount of cash paid by you, writing name of person and what paid for. Begin account by entering amount on hand.

What Paid for 
Finter on this page all money paid out by you, writing name of person you pay and what for,

What Paid for

T

10

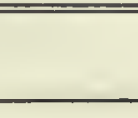


Enter on this page every amount of cash paid by you, writing name of person and what paid for. Begin account by entering amount on hand. 
Cash paid out by you in

Enter on this page all money paid out by you, writing name of person you pay and what for.

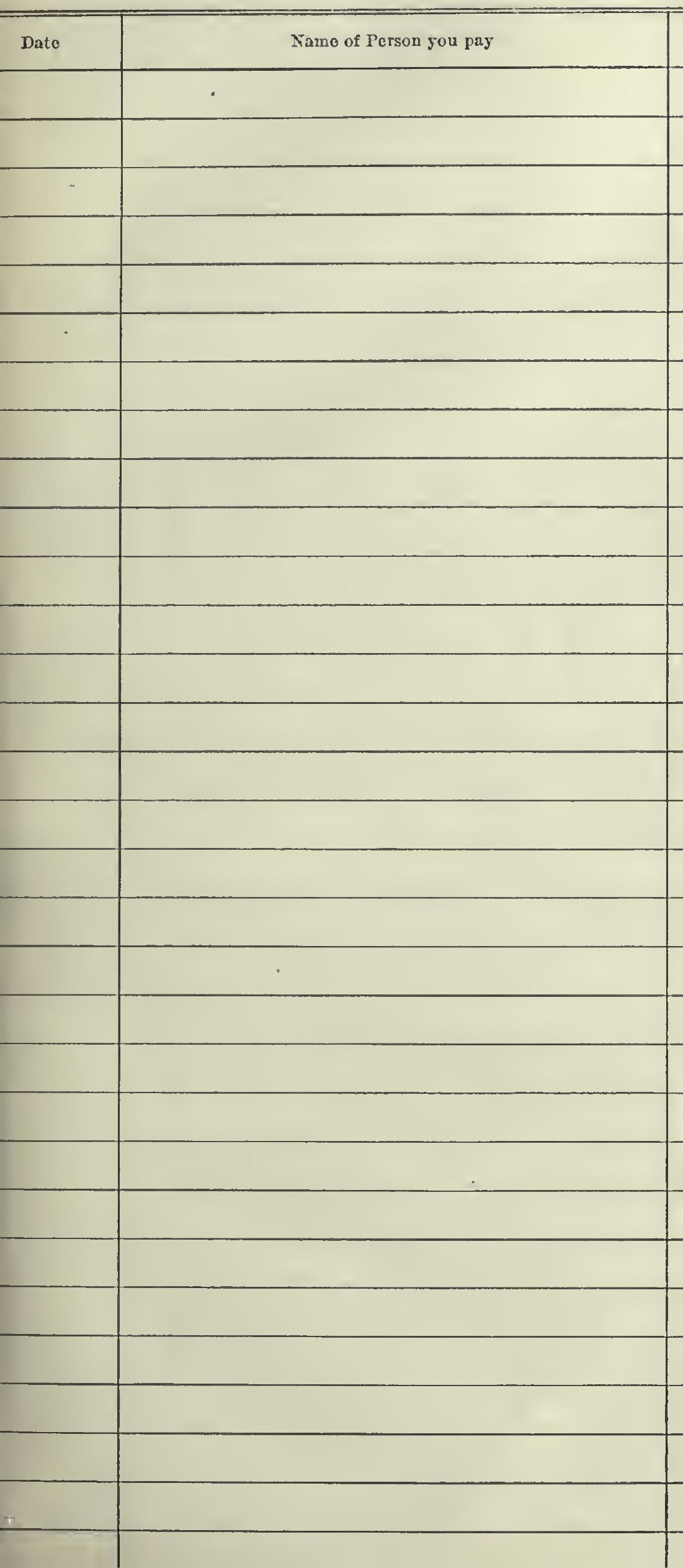

What Paid for

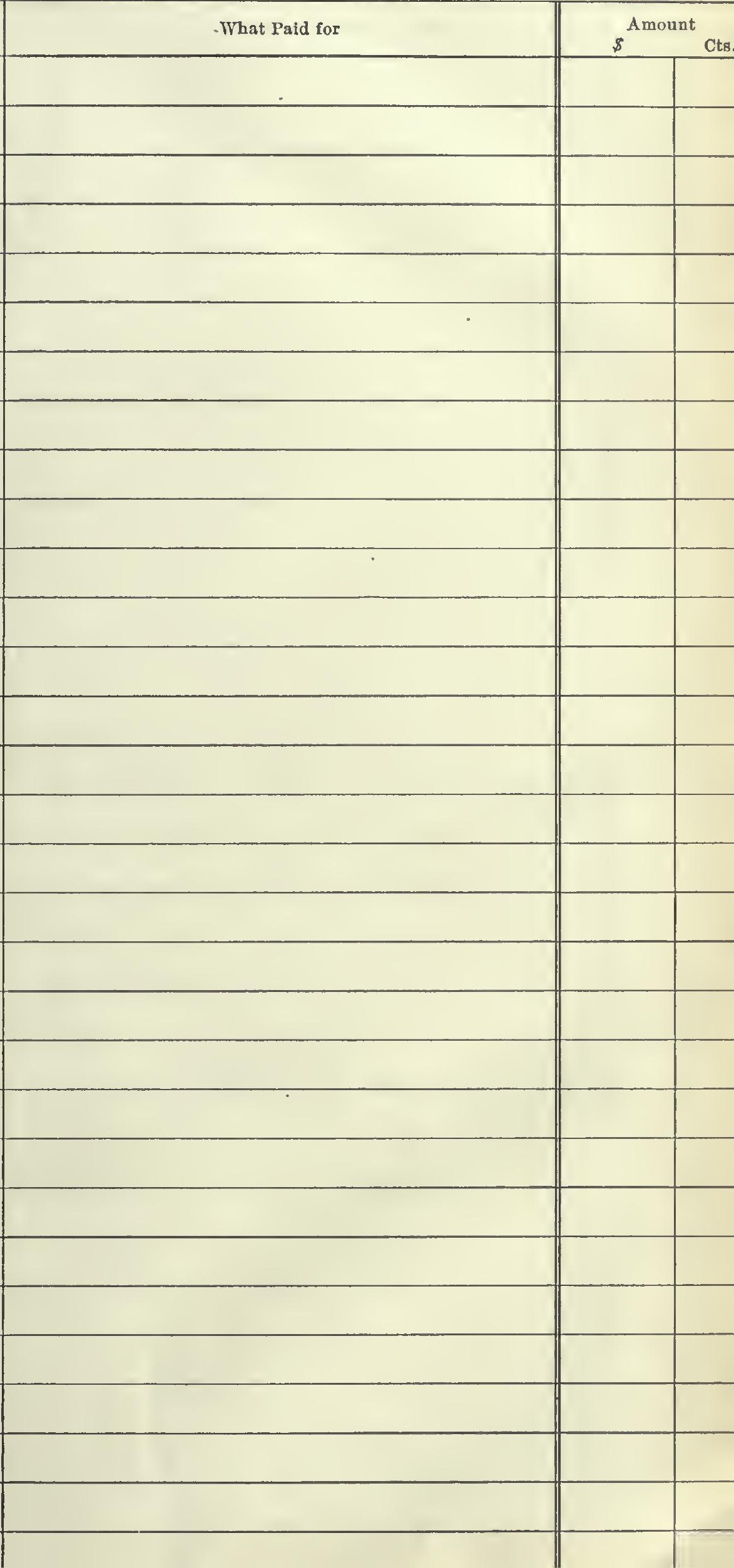


82 Cash received by you in

Enter on this pace every amount of cash paid by you, writing name of person and what paid for. Begin account by entering amount on hand.

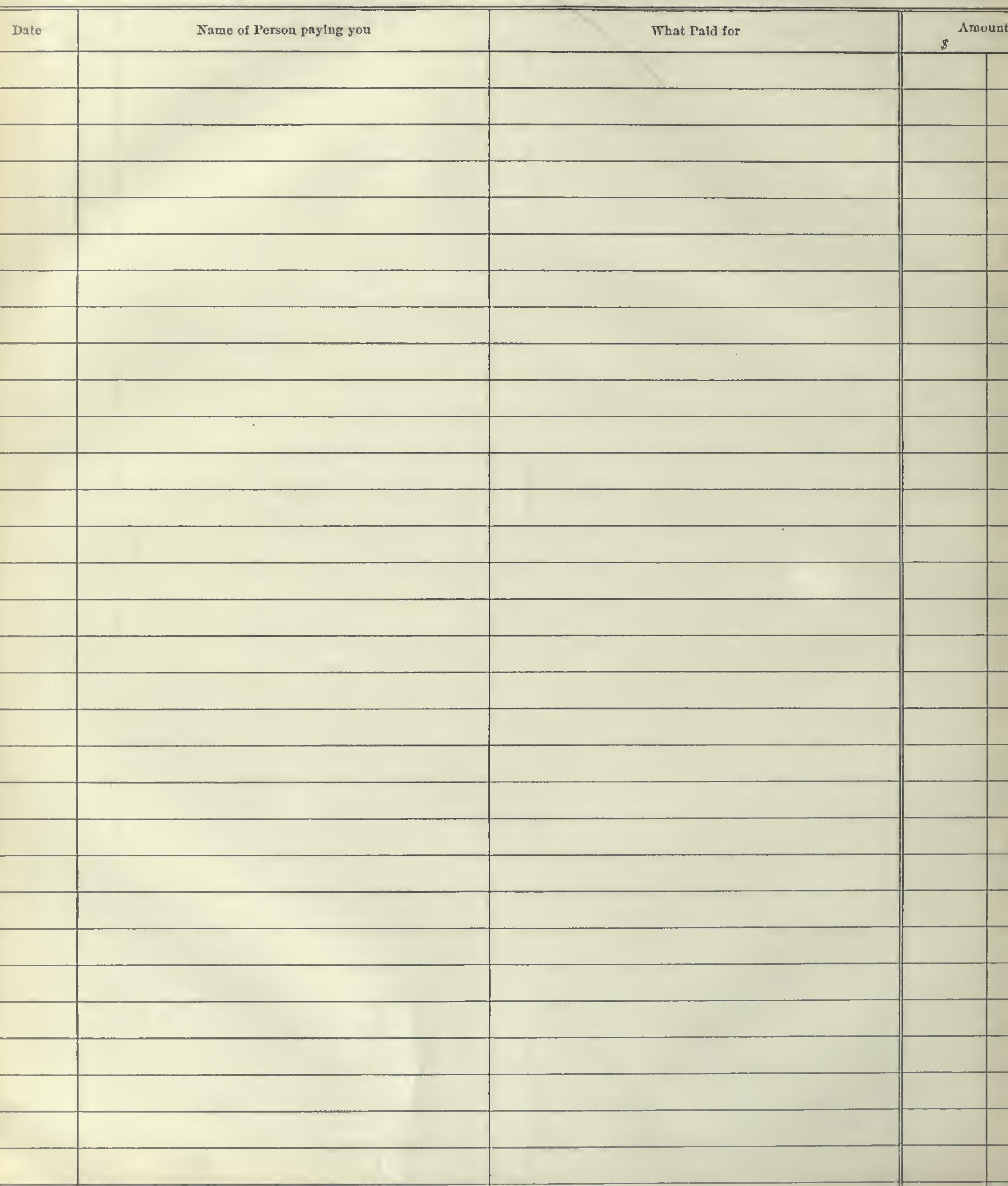


84 Cash received by you in

Enter on this page every amount of cash paid by you, writing name of person and what pa:d for. Begin account by entering amount on hand. 
Cash paid out by you in

Enter on this page all money paid out by you, writing name of person you pay and what for.

\begin{tabular}{|c|c|}
\hline Date & Name of Person you pay \\
\hline & \\
\hline & \\
\hline & \\
\hline & \\
\hline & \\
\hline & \\
\hline & \\
\hline & \\
\hline & \\
\hline & \\
\hline & \\
\hline & \\
\hline & \\
\hline & \\
\hline & \\
\hline & \\
\hline & \\
\hline & \\
\hline & \\
\hline & \\
\hline & \\
\hline & \\
\hline & \\
\hline & \\
\hline & \\
\hline & \\
\hline & \\
\hline & \\
\hline
\end{tabular}

What Paid for

Amount 
Enter on this page every amount of cash paid by you, writing name of person and what paid for. Begin account by entering amount on hand.

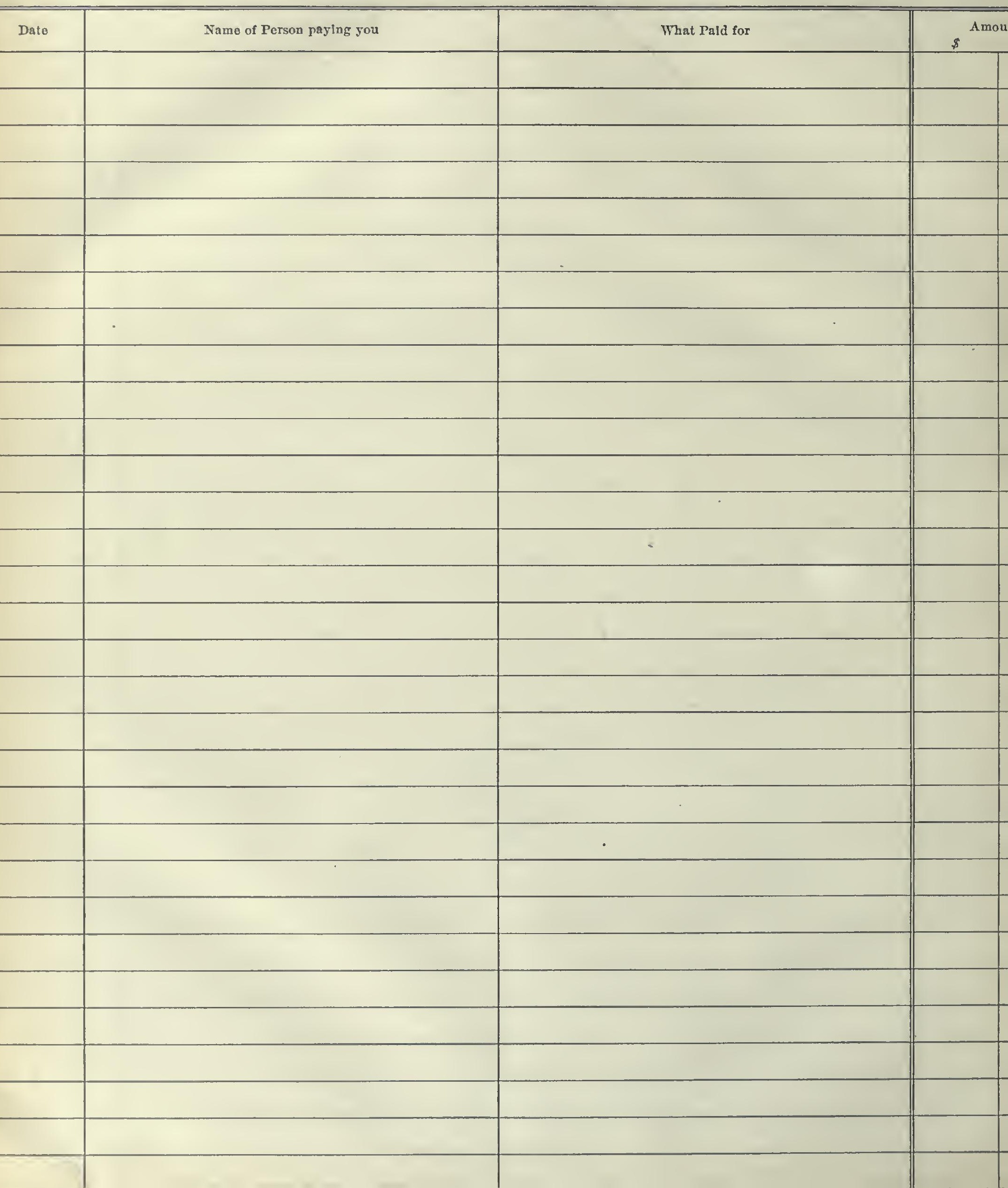


Enter on this page all money paid out by you, writing name of person you pay and what for. 
Enter on this page every amount of cash paid by you, writing name of person and what pa:d for. Bezin account by entering amount on hand. 
Cash paid out by you in

Enter on this page all money paid out by you, writing name of person you pay and what for. 
Enter on this page every amount of cash paid by you, writing name of person and what paid for. Begin account by entering amount on hand.

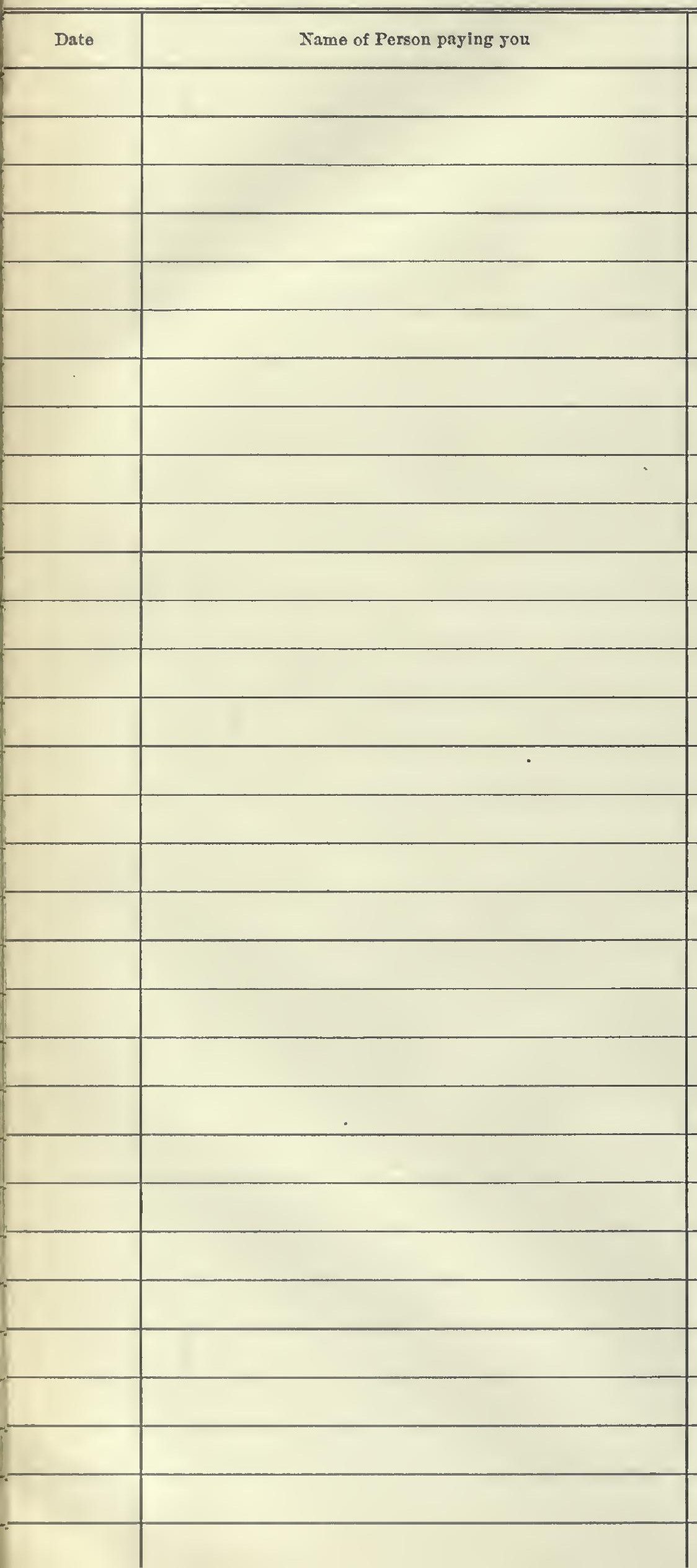

What Paid for

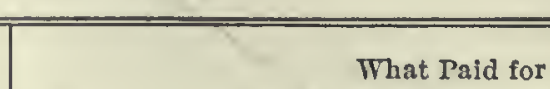


Cash paid out by you in

Enter on this page all money paid out by you, writing name of person you pay and what for. 
Enter on this page every amount of cash pald by you, writing name of person and whst paid for. Begin account by entering amount on hand.

Date

Name of Person paying you

What Pald for 
Enter on this page all money paid out by you, writing name of person you pay and what for. 
94 Cash received by you in.

Enter on this page every amount of cash paid by you, writing name of person and what paid for. Bezin account by entering amount on hand. 
Enter on this page all money paid out by you, writing name of person you pay and what for. 
Enter on this page every amount of cash paid by you, writing name of person and what paid for. Bezin account by entering amount on hand. 
Enter on this page every amount of cash paid by you, writing name of person and what paid for. Begin account by entering amount on hanl. 
Enter on this page every amount of cash paid by you, writing name of person and what paid for. Begin account by entering amount on hand. 
Enter on this page all money paid out by you, writing name of person you pay and what for.

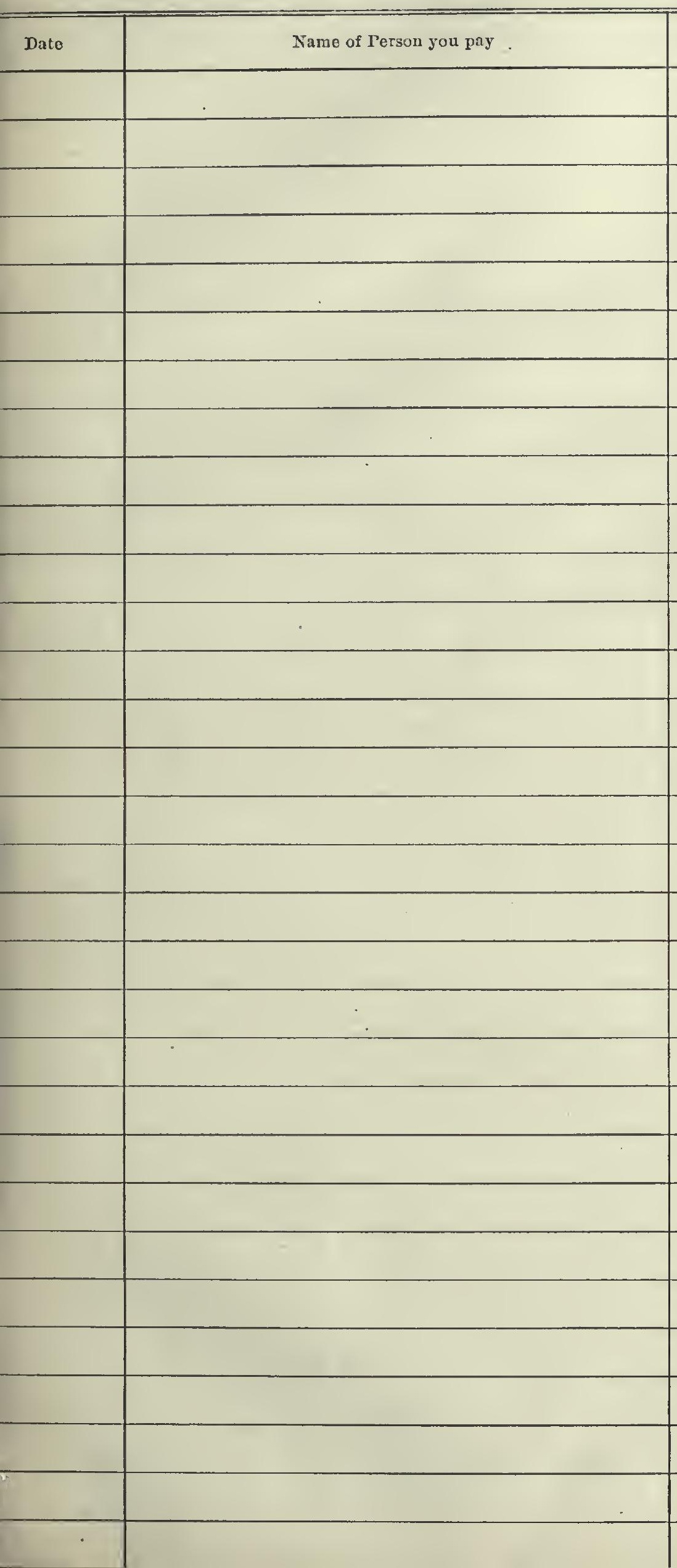

What Paid for 
Enter on this page every amount of cash pald by you, writing name of person and what paid for. Begin account by entering amount on hand. 
Enter on this page all money paid out by you, writing name of person you pay and what for. 
Enter on this page every amount of cash paid by you, writing name of person and what paid for. Begin account by entering amount on hand.

Amount

$\$$ 
Enter on this page all money paid out by you, writing name of person you pay and what for.

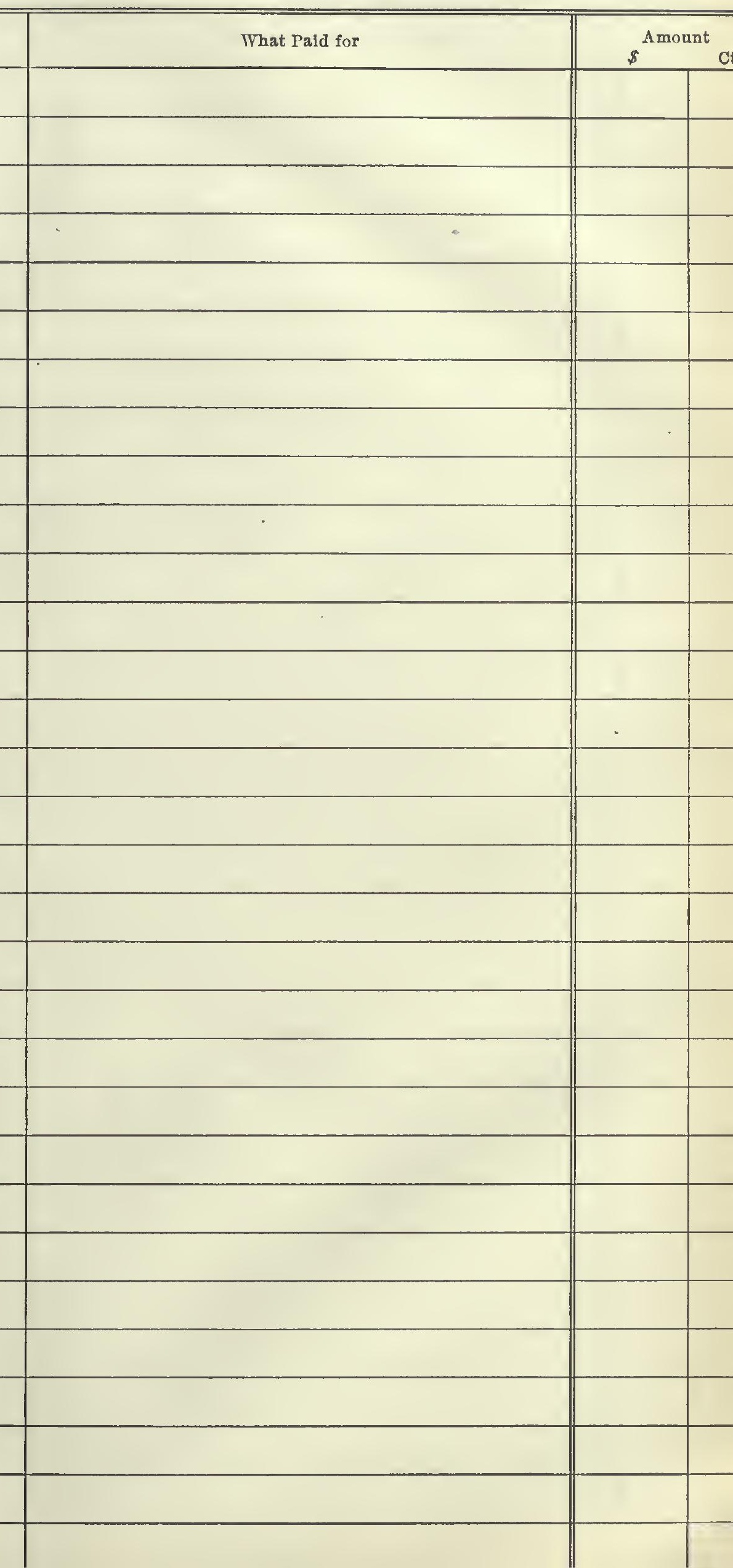


Enter on this page every amount of cash paid by you, writing name of person and what pa:d for. Begin account by entering amount on hand. 


\section{Cash paid out by you in}

Enter on this page all money paid out by you, writing name of person you pay and what for. 
Enter on this page every amount of cash paid by you, writing name of person and what pa!d for. Begin account by entering amount on hand. 
Enter on this page all money paid out by you, writing name of person you pay and what for. 
Enter on this page every amount of cash paid by you, writing name of person and what paid for. Bezin account by entering amount on hand.

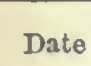

$\mid$

\section{Name of Person paying you}

What Pald for 
Enter on this page all money paid out by you, writing name of person you pay and what for.

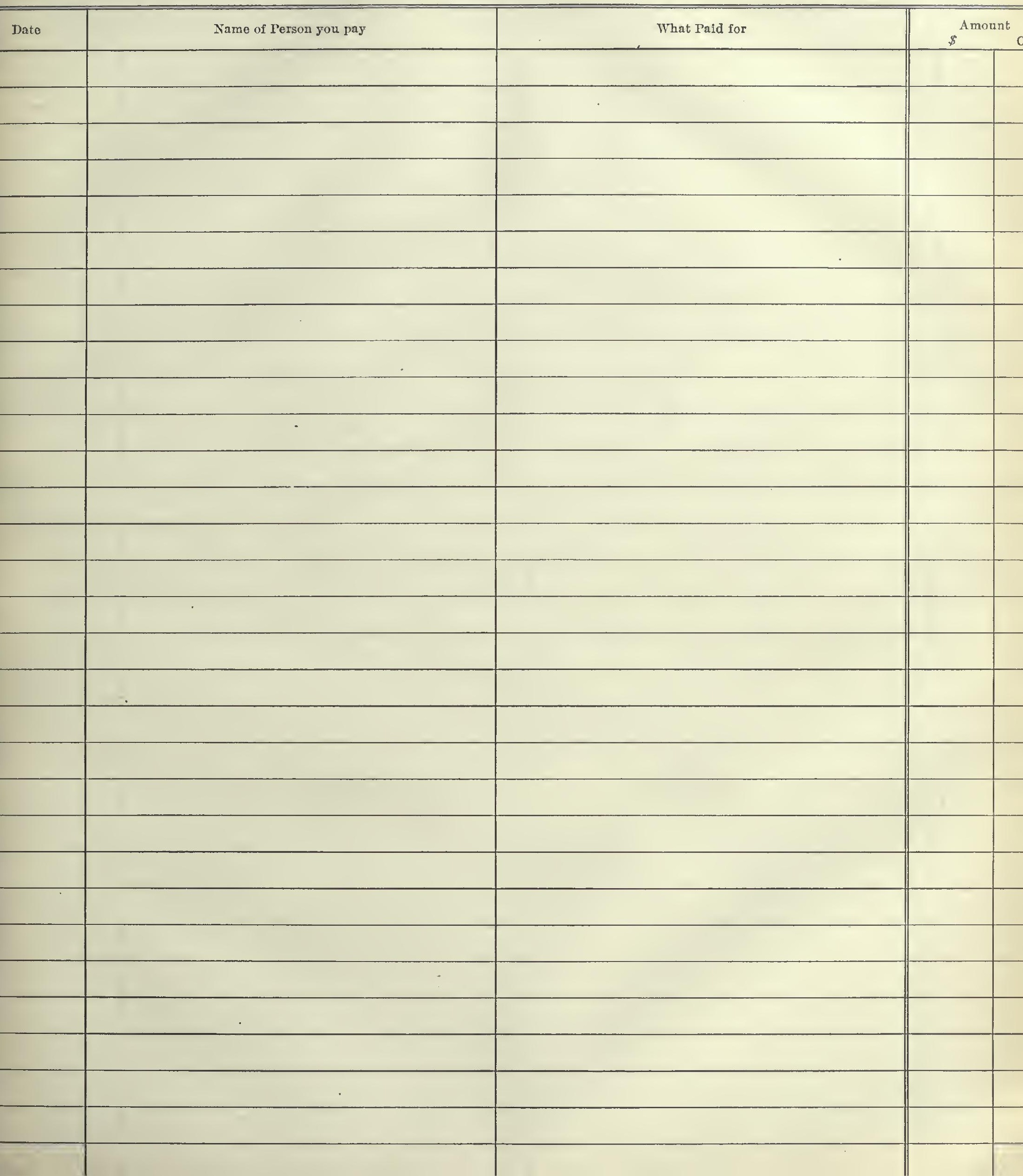


Enter on this page every amount of eash paid by you, writing name of person and what paid for. Bezin account by entering amount on hand. 
Enter on this page all money paid out by you, writing name of person you pay and what for. 
Enter on this page every amount of cash paid by you, writing name of person and what paid for. . Begin account by entering amount on hand. 
Cash paid out by you in

Enter on this page all money paid out by you, writing name of person you pay and what for. 
Enter on this page every amount of cash paid by you, writing name of person and what paid for. Begin account by entering amount on hand. 
Enter on this page all money paji out by you, writing name of person you pay and what for. $\mathrm{C}$ 
Enter on this page every amoant of cash paid by you, writing name of person and what paid for. Begin account by entering amount on hand.

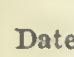

Date
Name of Person paying you
What Paid for
Amount 
Cash paid out by you in

Enter on this page all money paił out by you, writing name of person you pay and what for.

What Paid for 
Enter on this page every amount of cash paid by you, writing name of person and what paid for. Bezin account by entering amount on hand.

Date

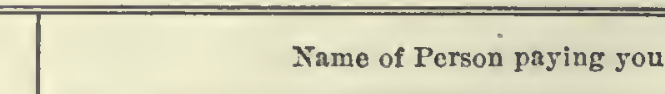

What Pald for

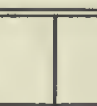

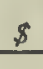




\section{CROP COST SHEET}

Enter on this side labor, men and teams. ploughing, cultivating and harvesting, Cost of seed and fertilizer, hauling to market or freight charges, rent or any other cost.

LoT_

CROP

Enter on this side sales made, stating name of buyer, amount sold and prices per bushel or ton. Also credit for amount consumed on farm.

SEASON OF

Amount

\begin{tabular}{|l||l|l|}
\hline Cts. & Date & \\
\hline
\end{tabular}

Item

Amount $\$$ 
Enteir on this side labor, men and teams ploughing, eultivating and harvesting, Cost of seed snd fartilizer, havling to market or freight eharges, rent or any other cost.

LOT CROP

Item
Enter on this side sales made, stating name of buyer, amount sold and prices per bushel or ton Also eredit for amount consumed on farm.

SEASON OF. 191

\section{Date}

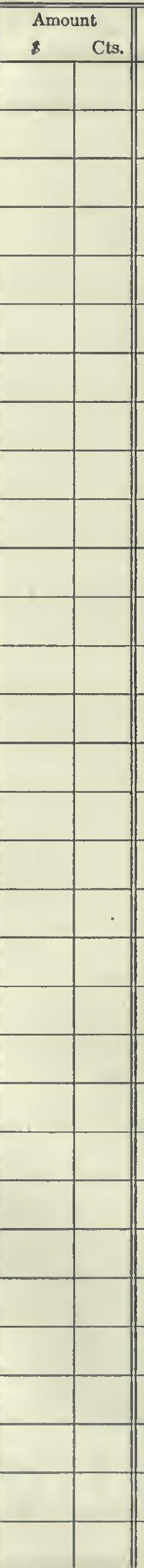

Amount $s$

\section{SUMMARY}

Acres in Lot

Total cost to produce (BUSUEL OK TON)

Cost per Sales netted
Production

Valuo

Production per acre 
Enter on this side labor, men and teams, ploughing, cultivating and harvesting, Cost of seed and fertilizer, hauling to market or freight charges, rent or any other cost.

LOT

CROP

Item
Fiter on this side gales made, stating name of huyer, amount sold and prices per bus 2 Also credit for amount consumed on farm.

SEASON OF

191

\section{Date}

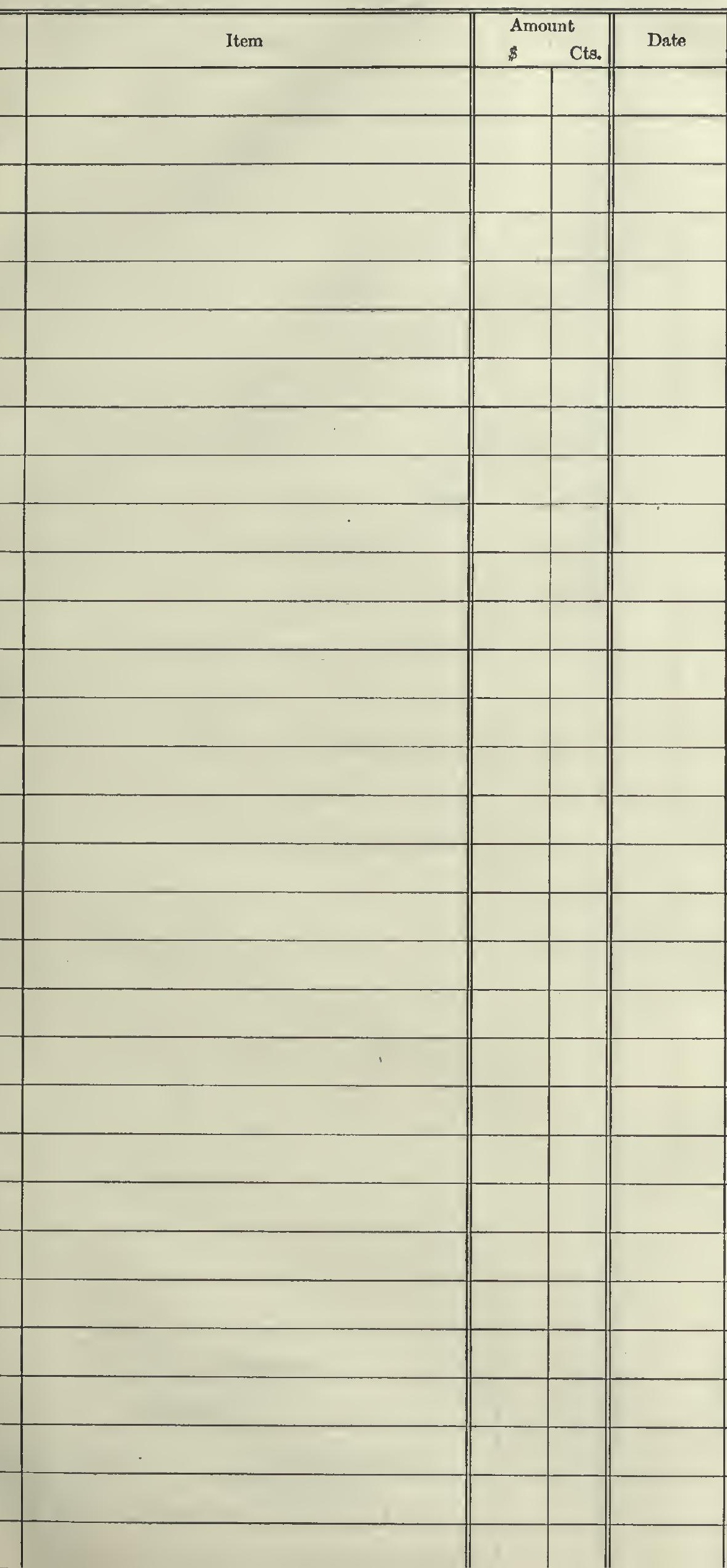

Amount

\section{Item}


Enter on this uide labor, men and teams, ploughing, ealtivating and harvesting, Cost of seed and fertilizer, hauling to market or freight changes, rent or any other cost.

I, OT

Crop

Item
Enter on this side sales made, stating name of buyer, amount sold and prices per bushel or ton Also eredit for amount consumed on farm.

SEASON OF 191

Item

SUMMARY

Acres in Lot

Production

Total eost to produco

(BUSHEL OR TON)

Cost per

Sales netted

Production per acre 


\section{CROP COST SHEET}

Fnter on this side labor, men and teams. ploughing, cultivating and harvesting, Cost of seed and fertilizer, hauling to market or freight charges, rent or any other cost.

LoT

Crop

Item
Enter on this side sales made, stating name of buyer, amount sold and pricesper bushel or ton, Also credit for amount consumed on farm.

SEASON OF 191

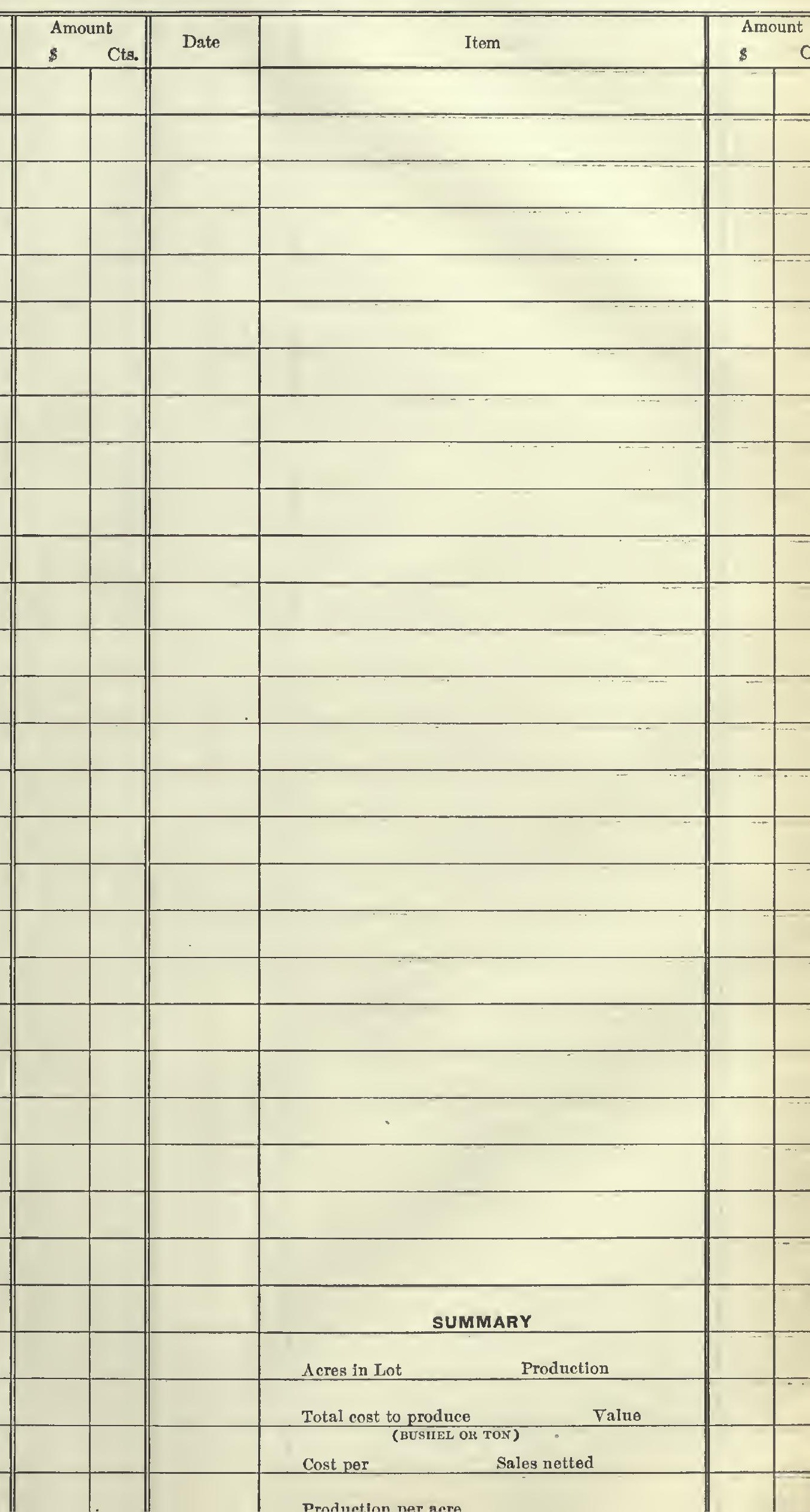


Enter on this aide labor, men and teams, plooghing, cultivating and harvesting, Cost of seed and fartilizer, havling to market or freight charges reat or any other cost.

LoT

Crop

Item

Ite

1|

Amount

m
Amount
Enter on this side sales made, stating name of buyer, nmount sold and prices per bushel or ton Also credit for amount coniumed on farm.

SEASON OF 191
Date

Item
Amount

$\$$
SUMMARY

Aeres in Lot

Production

Total cost to produce

(BUSIIEL OK TOX)

Cost ner

Sales netted 
Enter on this side labor, men and teams. ploughing, cultivating and harvesting, Cost of seed and fertilizer, hauling to market or freight charges, rent or any other cost.

LoT

CROP
Fnter on this gide sales made, stating name of buyer, amount sold and prices per bushel or ton. Also credit for amount consumed on farm.

SEASON OF

191 (1)

\section{Date}

$=$

Item

\begin{tabular}{|c|c|c|}
\hline & Amount & Doto \\
\hline tem & Cts. & Date \\
\hline
\end{tabular}

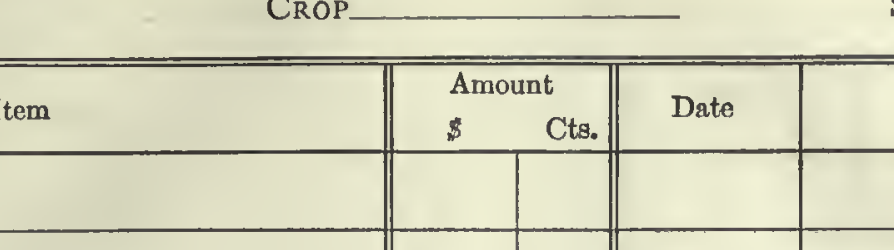

127

\begin{tabular}{|l||l|l|}
\hline Item & \multicolumn{2}{|c|}{ Amount } \\
& $\$$ \\
\hline
\end{tabular}



Entcr on this side labor, men and teams, ploughing, cultivating and harvesting, Coot of seed
and fartilizer, hauling to market or freight charges, rent or any other cost.

LOT

CROP

Item
Enter on this side sales made, stating name of buyer, amount sold and prices per bushel or ton Also credit for amount consumed on farm.

SEASON OF 191

\begin{tabular}{l|l}
\hline Date & Item \\
\hline
\end{tabular}


Enter on this side labor, men and teams. ploughing, cultivating and harvesting. Cost of seed and fertilizer, hauling to market or freight charges, rent or any other cost.

LoT.

Crop
Fnter on this side sales made atating name of buyer, amount sold and prices per bughe or ton Also credit for amount consumed on farm.

SEASON OF

191

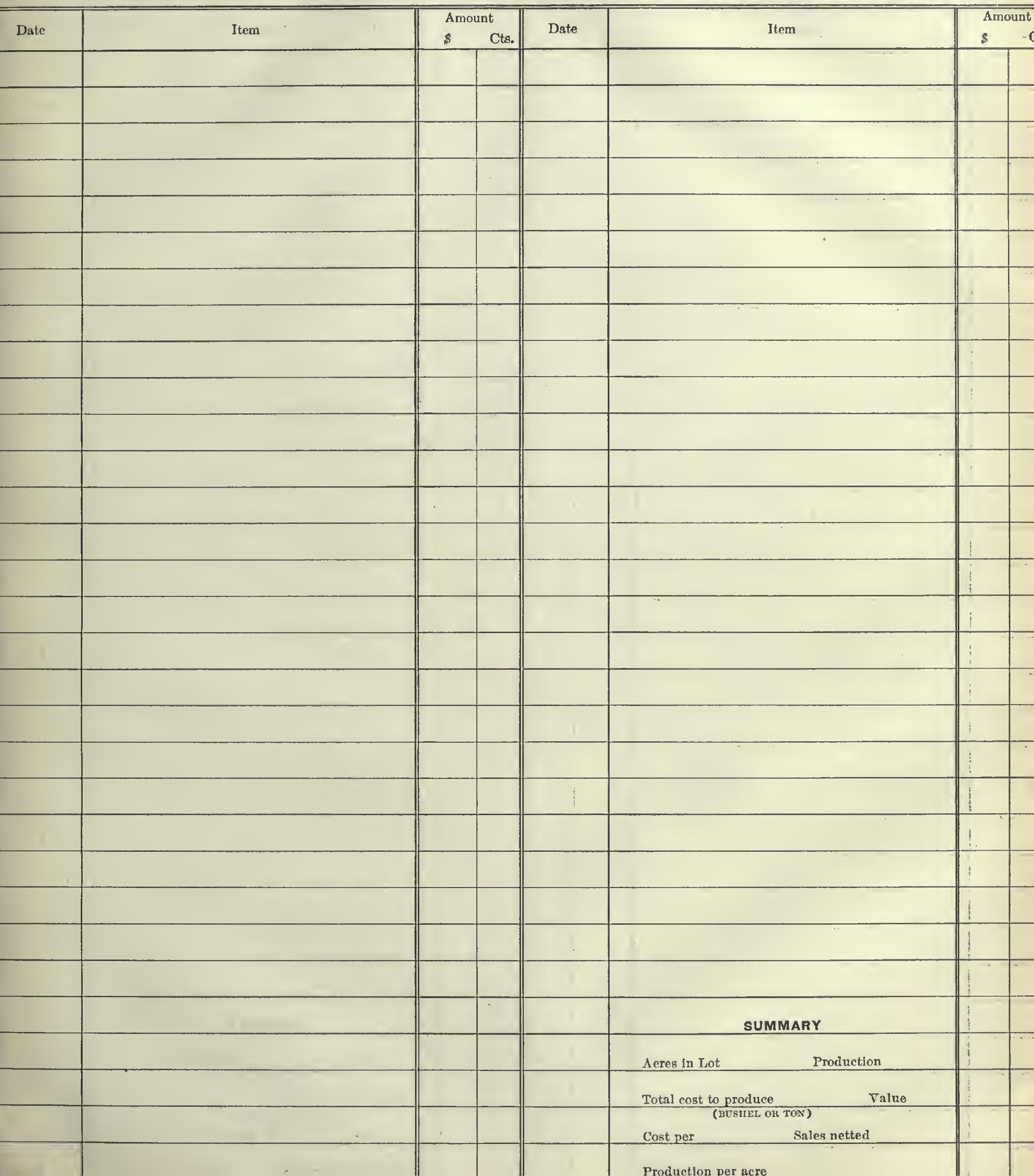


Enter on this slde labor, meh and teams. ploughing, eultivating and harveating, Cost of secd and fartilizer, hanling to market or freight charges, rent or any other cost.

IoT CROP

Item

\section{Amount}

Enter on this side zales made, stating name of buyer, smount sold and prices per bushel or ton Also credit for amount consumed on farm. 191

\section{SEASON OF}

Ite

Date

Date


Enter on this side labor, men and teams. ploughing, cultivating and harvesting, Cost of seed and fertilizer, hauling to market or freight charges, rent or any other cost.

\section{LOT}

Crop Enter on this side sales made, stating name of buyer, amount sold and prices per boushel or ton,
Also credit for smount consumed on farm.

SEASON OF 191

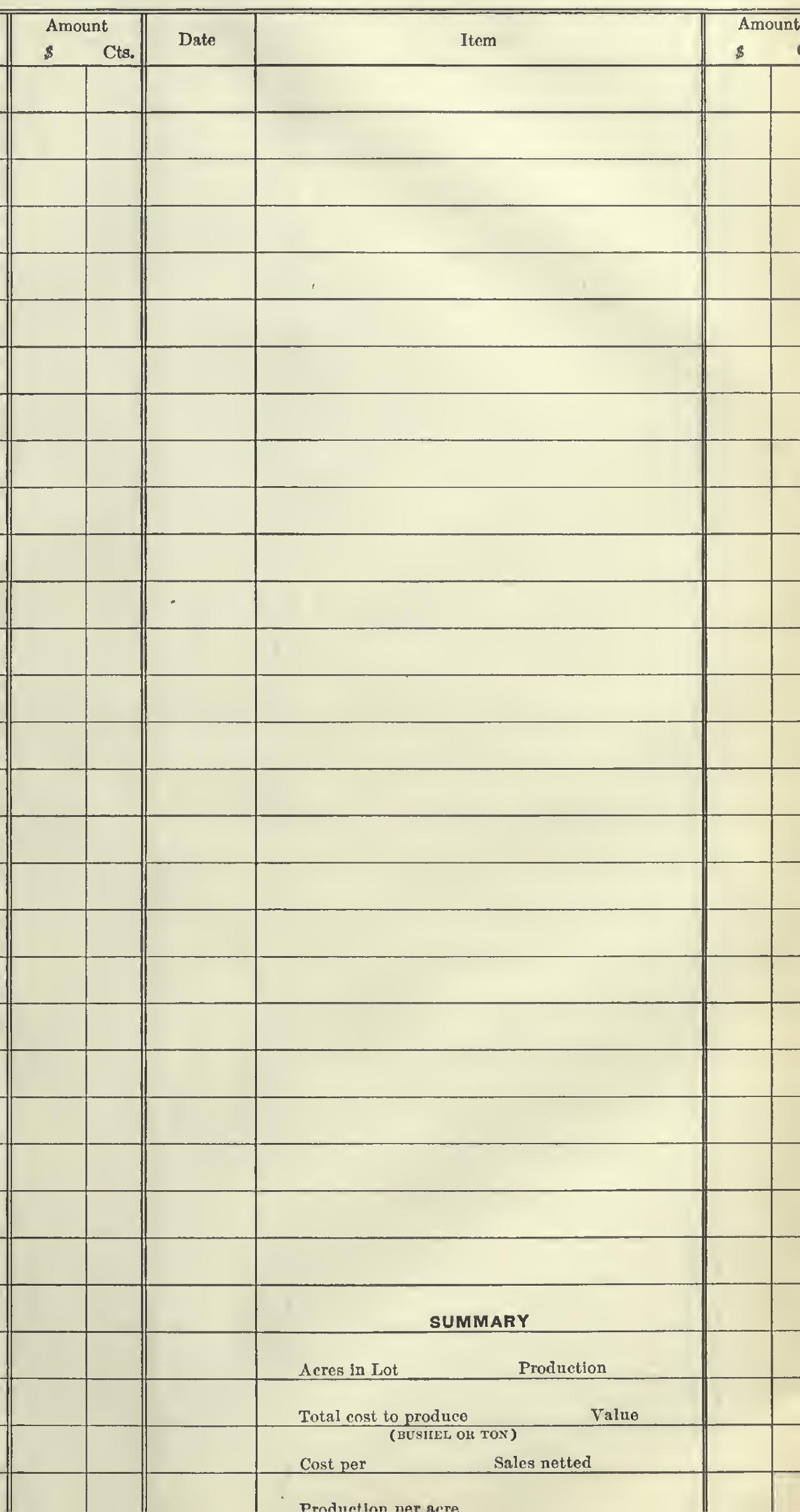


Enter on this side labor, men and teams. ploughing, cultivating and harvesting, Cost of seed and fertilizer, hauling to market or freight charges, rent or any other cost.

LoT.

Crop
Finter on this gides ales made, stating name of buyer, amount sold and prices per bus Also credit for amount consumed on farm.

SEASON OF 191

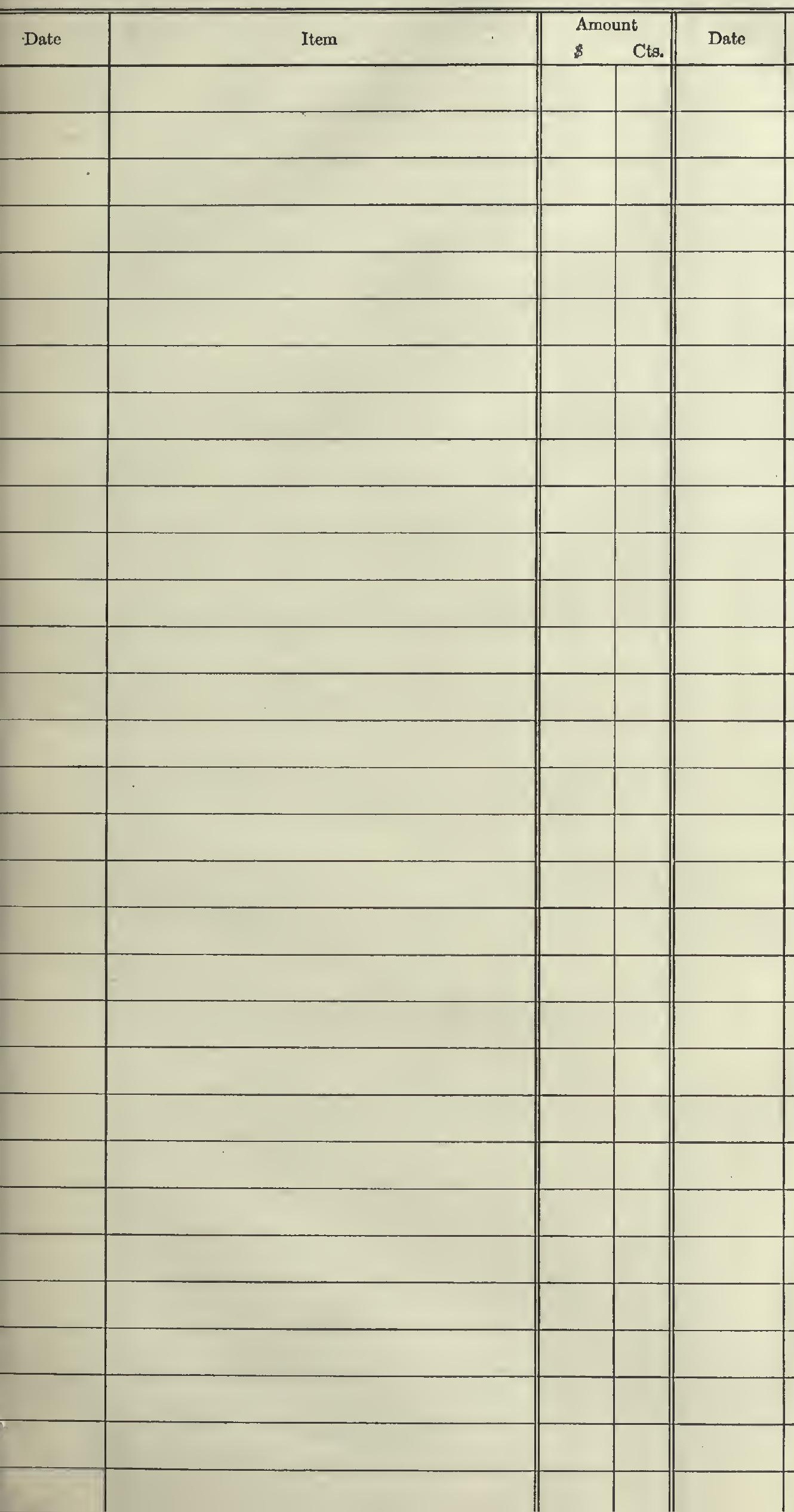


Enter on this aide labor, men and teams. ploughing, eultivating and harresting, Cost of seed and fertilizer, hauling to market or freight charges, rent or any other cost.

LOT

CROP
Enter on this side Bales made, stating name of buyer, amount sold and prices per bushel or ton Also credit for amount consumed on farm.

SEASON OF 191
Date
Item
Amount

$\$$
Date

Item
Amount

$s$ 
Enter on this side labor, men and teams. ploughing, cultivating and harvesting, Cost of aeed and fertilizer, hauling to market or freight charges, rent or any other cost.

LoT.

Crop

Item
Fner on 1 e Also credit for amount consumed on farm.

SEASON OF 191

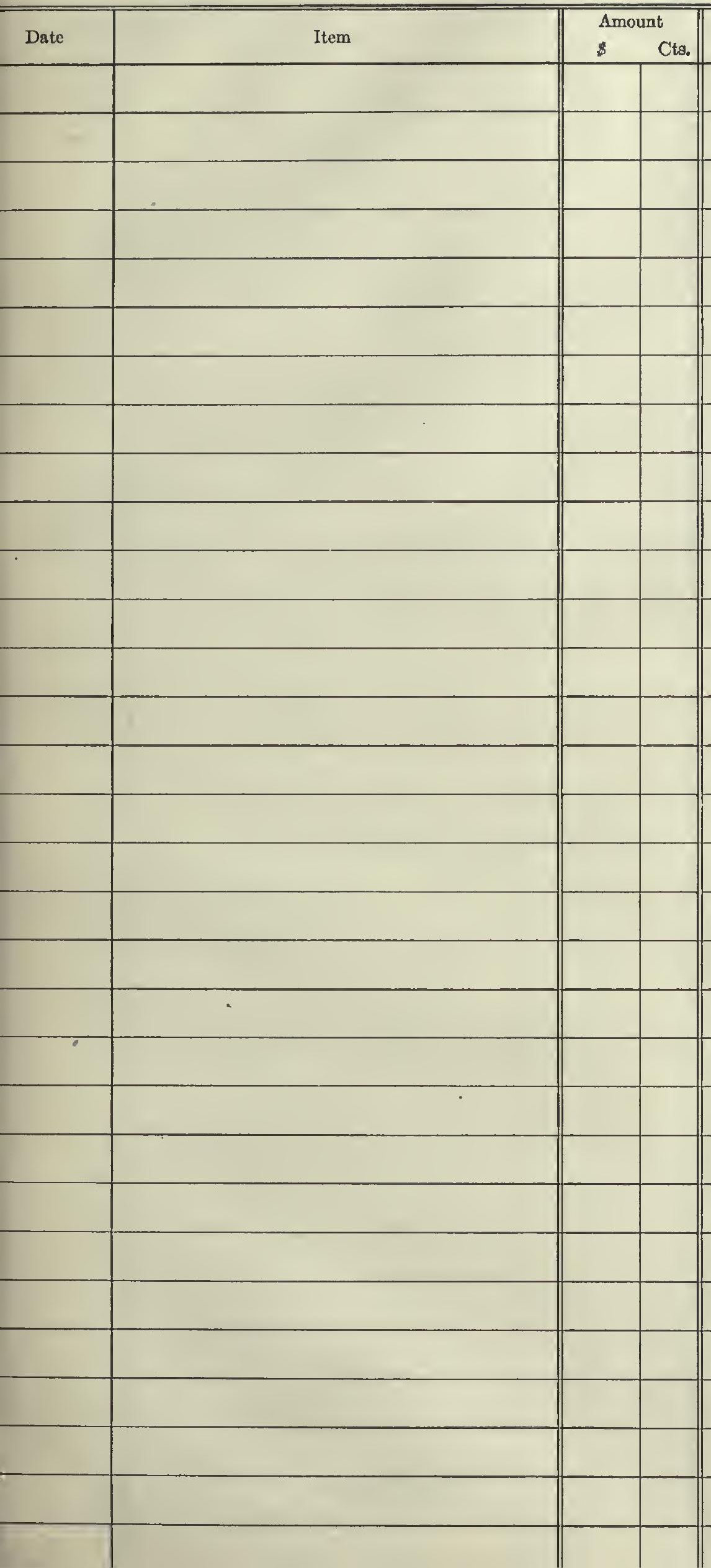

Date
Item

Amount

C


Enter on this side labor, men and teams. ploughing, cultivating and harvesting, Cost of seed and fertilizer, hauling to market or freight charges, rent or any other cost.

LoT

Crop
Enter on this side sales made, stating name of buyer, amount sold and prices per bushel or ton Also credit for amount consumed on farm. 191
Item

Date

Item

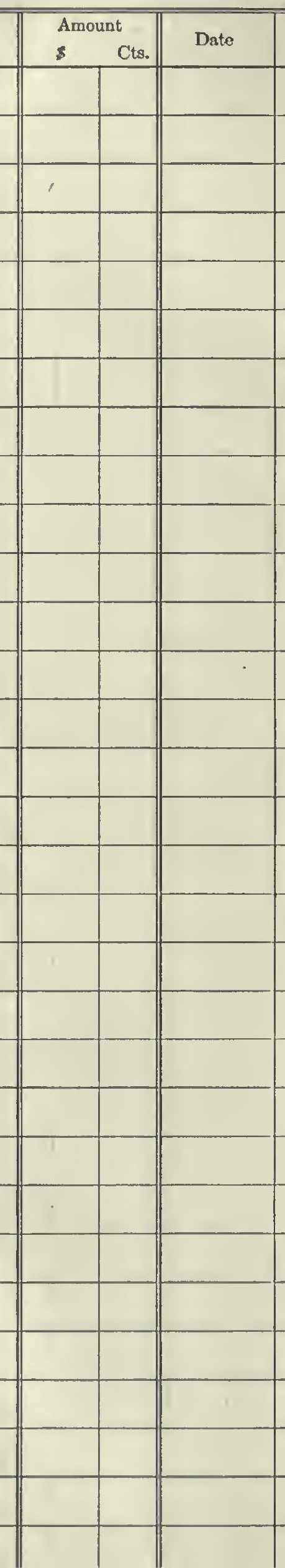

SEASON OF 
Entex on this side labor, men and teams. ploughing, cultivating and harvesting, Cost of seed and fertilizer, hauling to market or freight charges, rent or any other cost.

LoT.

$$
\text { Crop }
$$

Item
Tnter on this Also credit for amount consumed on farm.

SEASON OF 191

\section{Datc}

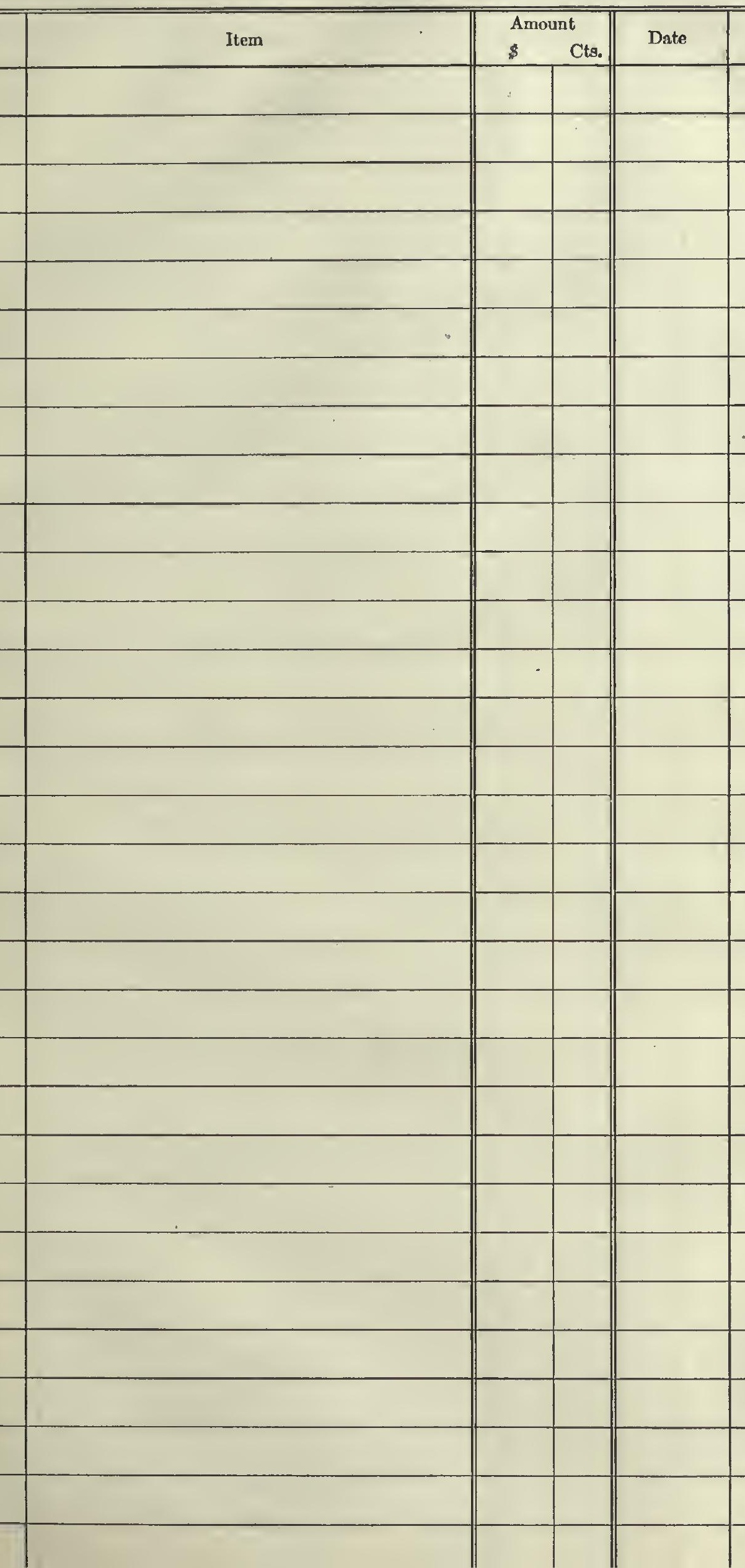

\section{Sach on}

Item



Enter on this side labor, men snd teams, ploughing, cultivating and harvesting, Cost of seed
and fertilizer, hauling to market or freight charges, rent or any other cost.
IOT
CROP

Item
Enter on this side sales made, stating name of buyer, smount sold and prices per bushel or ton Also credit for amount consumed on farm.

SEASON OF 191

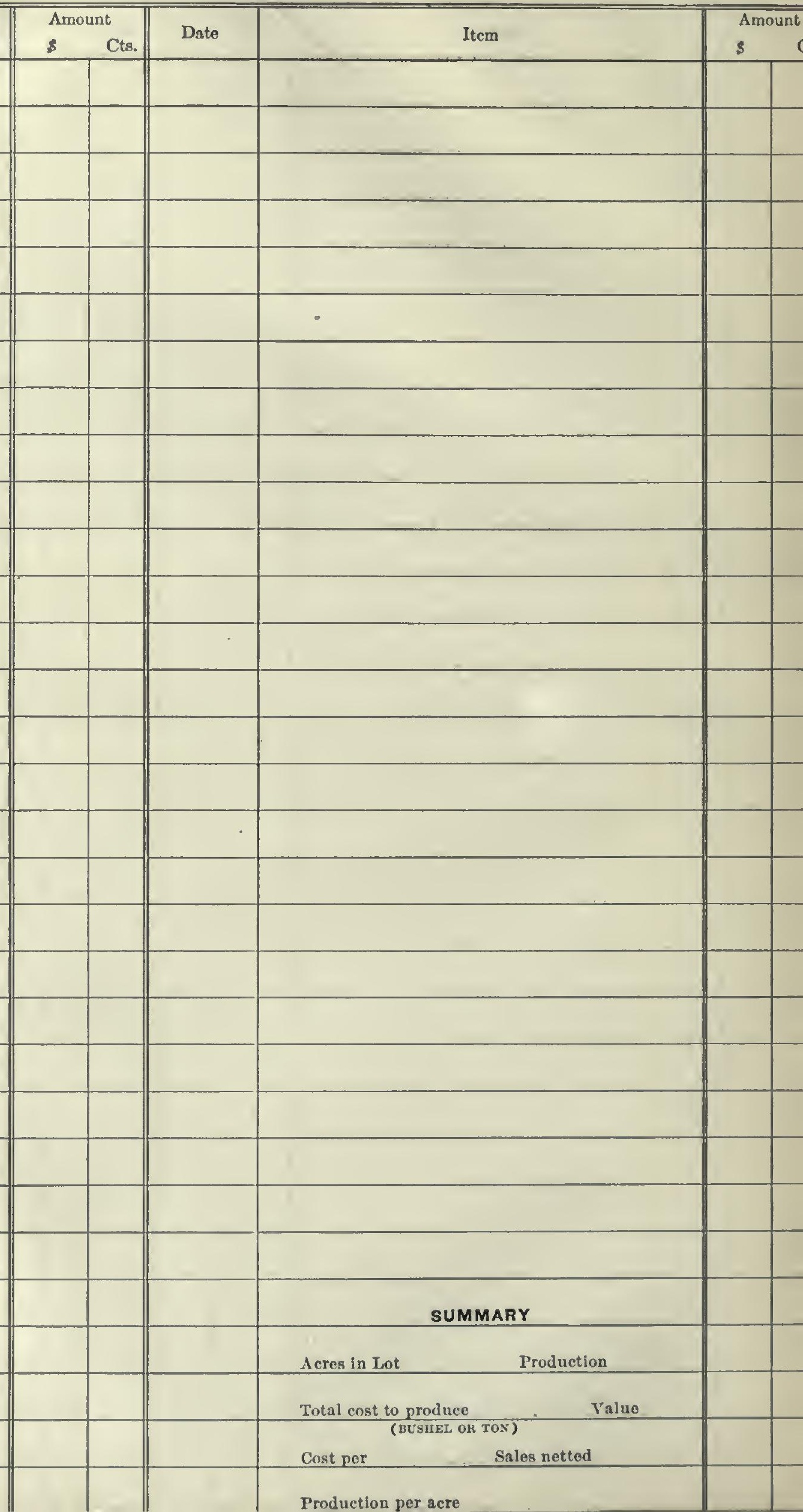


bushel or ton.

Enter on this side labor, men and teams. ploughing, cultivating and harvesting, Cost of seed and fertilizer, hauling to market or freight charges, rent or any other cost.

LoT

CROP

Item

Item

Also credit for amount consumed on farm.

SEASON OF 191
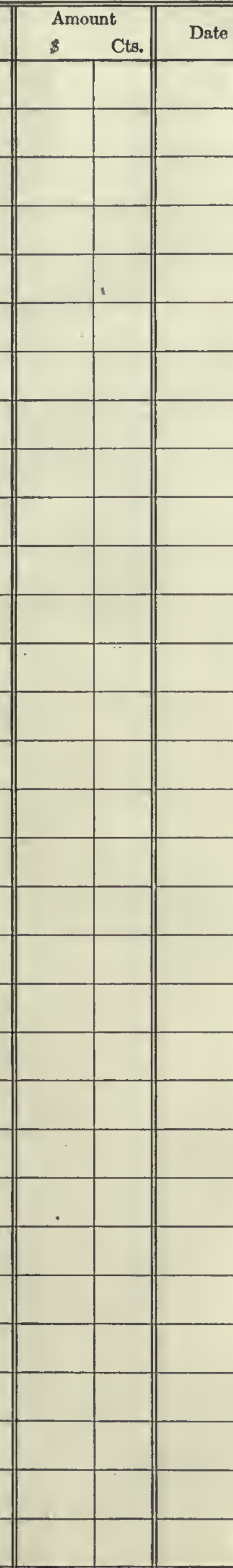
Enter on this side labor, men and teams, ploughing, cultivating and harvesting, Cost of seed and fartilizer, hauling to market or freight charges, rent or any other cost.

LoT.

CROP

Item
Amount
Enter on this side sales made, stating name of buyer, amount sold and prices per bushel or ton Aiso credit for amount consumed on farm.

SEASON OF 191
Date

Item

Date

\section{Item}

SUMMARY

Acres in Lot

Total rost to produce

(BUSHEL OH TON)

Cost per

Sales netted
Production

Value

Production ner acre 
Enter on this side labor, men and teams. ploughing, cultivating and harvesting, Cost of seed and fertilizer, hauling to market or freight charges, rent or any other cost.

LoT

Crop

Item

T.

Enter on this side sales made, stating name of buyer, amount sold and prices per bushel or ton. Also credit for amount consumed on farm.

SEASON OF 191

\section{Date}

Amount

Date

\section{Item}




\section{2 \\ CROP COST SHEET}

Enter on this shde labor, men and teams, plonghing, cultivating and harvesting. Cost of seed and fertilizer, hanling to market or freight charges, rent or any other cost.

Lor.

CROP

Item
Enter on this side sales made, stating name of buyer, amount sold and prices per bushel or ton Also credit for amount consumed on farm.

SEASON OF 191.

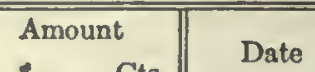

$$
s
$$

(1)
Date

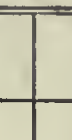




\section{CROP COST SHEET}

Enter on this side labor, men and teams. ploughing. cultivating and harvesting, Cost of seed and fertilizer, hauling to market or freight charges, rent or any other cost.

LoT

CROP

Item
Enter on this side sale

Enter on this side sales mad stating name of buyer, amount sold and prices per bugh Also credit for amount consumed on farm.

SEASON OF

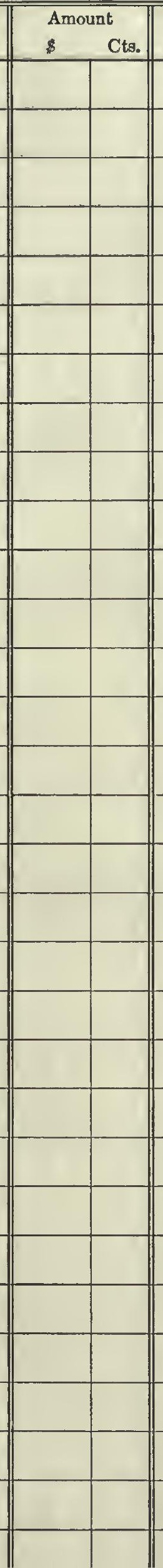

Date

Itcm
Amount
143 
Enter on this aide labor, men and teams. ploughing, cultivating and harvesting, Cost of seed and fertilizer, hauling to market or freight eharges, sent or any other cost.

LOT Crop Item

Item

Enter on this side sales made, stating name of huyer, amount sold and prices per bushel or ton Also credit for amount consumed on farm.

SEASON OF 191

Date

SUMMARY

Acres in Lot

Production

Total cost to produce

(BUSHEL OK TON)

Cost per

Sales netted

Production per acre
Amount

$s$ 
THIS PAGE MAY BE USED FOR MORE THAN ONE MONTH BY WRITING NAME OF ACCOUNT BELOW SPACE USED FOR PRECEDING MONTH.

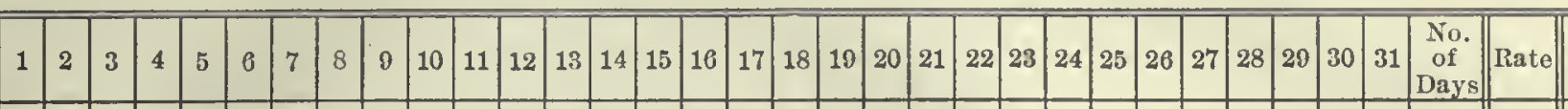
$\$ \quad \mathrm{Ct}$ 
THIS PAGE MAY BE USED FOR MORE THAN ONE MONTH BY WRITING NAME OF ACCOUNT BELOW SPACE USED FOR PRECEDING MONTH.

Name of Torkman

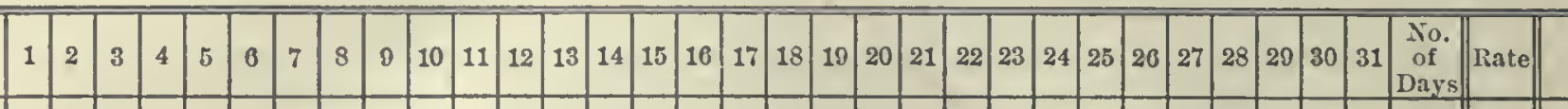


THIS PAGE MAY BE USED FOR MORE THAN ONE MONTH BY WRITING NAME OF ACCOUNT BELOW SPACE USED FOR PRECEDING MONTH. 
THIS PAGE MAY BE USED FOR MORE THAN ONE MONTH BY WRITING NAME OF ACCOUNT BELOW SPACE USED FOR PRECEDING MONTH.

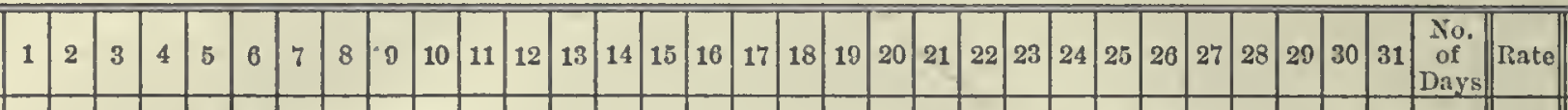


BREEDING TABLE

MARE-Average about 340 days. SOW-A verage about 112 days.

TIME OF GESTATION FROM SERVICE TO BIRTH

\begin{tabular}{|c|c|c|}
\hline Kind of Animal & Name or Description & Date Due \\
\hline & & \\
\hline & & \\
\hline & & \\
\hline & & \\
\hline & & \\
\hline & & \\
\hline & & \\
\hline & & \\
\hline & & \\
\hline & & \\
\hline & & \\
\hline & & \\
\hline & & \\
\hline & & \\
\hline & & \\
\hline & & \\
\hline & & \\
\hline & & \\
\hline & & \\
\hline & & \\
\hline & & \\
\hline & & \\
\hline & & \\
\hline & & \\
\hline & & \\
\hline & & \\
\hline & & \\
\hline & & \\
\hline & & \\
\hline & & \\
\hline & & \\
\hline
\end{tabular}

COW-Average about 283 days.

EWE-Average about 150 days. 


\section{INSTRUCTIONS FOR USE}

Daily Records of milkings morning and evening should be carefully kept on weekly cards, which may be purchased for the purpose; or records may be kept on any plain pad and entered at the end of each week.

Month of

191 _ Month of

191 M K Month of

191

NAME OF COW

\begin{tabular}{|c||c|c|c|c|c|c||c|c|c|c|c|c||c|c|c|c|c|c|c}
\hline Cow No. & $\begin{array}{c}\text { 1st } \\
\text { Week }\end{array}$ & $\begin{array}{c}\text { 2nd } \\
\text { Week }\end{array}$ & $\begin{array}{c}\text { 3rd } \\
\text { Week }\end{array}$ & $\begin{array}{c}\text { 4th } \\
\text { Week }\end{array}$ & $\begin{array}{c}\text { 5th } \\
\text { Week }\end{array}$ & $\begin{array}{c}\text { Total } \\
\text { for } \\
\text { Ion. }\end{array}$ & $\begin{array}{c}\text { 1st } \\
\text { Week }\end{array}$ & $\begin{array}{c}\text { 2nd } \\
\text { Week }\end{array}$ & $\begin{array}{c}\text { 3rd } \\
\text { Week }\end{array}$ & $\begin{array}{c}4 \text { th } \\
\text { Week }\end{array}$ & $\begin{array}{c}\text { 5th } \\
\text { Week }\end{array}$ & $\begin{array}{c}\text { Total } \\
\text { for } \\
\text { 3on. }\end{array}$ & $\begin{array}{c}\text { 1st } \\
\text { Week }\end{array}$ & $\begin{array}{c}\text { 2nd } \\
\text { Week }\end{array}$ & $\begin{array}{c}\text { 3rd } \\
\text { Week }\end{array}$ & $\begin{array}{c}4 \text { th } \\
\text { Week }\end{array}$ & $\begin{array}{c}\text { 5th } \\
\text { Week }\end{array}$ & $\begin{array}{c}\text { Total } \\
\text { Wor } \\
\text { Ion. }\end{array}$ \\
\hline
\end{tabular}
1

2

3

4

5

6

7

8

$\theta$

10

11

12

13

14

15

16

17

18

10

20

21

22

28

24

25

26

27

28

20

30 
INSTRUCTIONS FOR USE

As all Months have a day or two over four weeks this record has been prepared with spaces for five weeks, the fifth space being intended for the record of the extra days in the month.

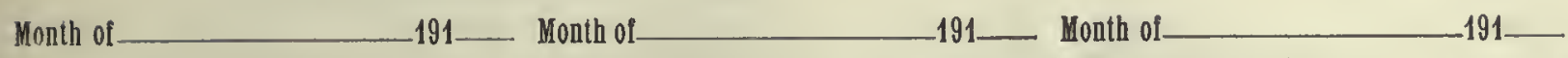

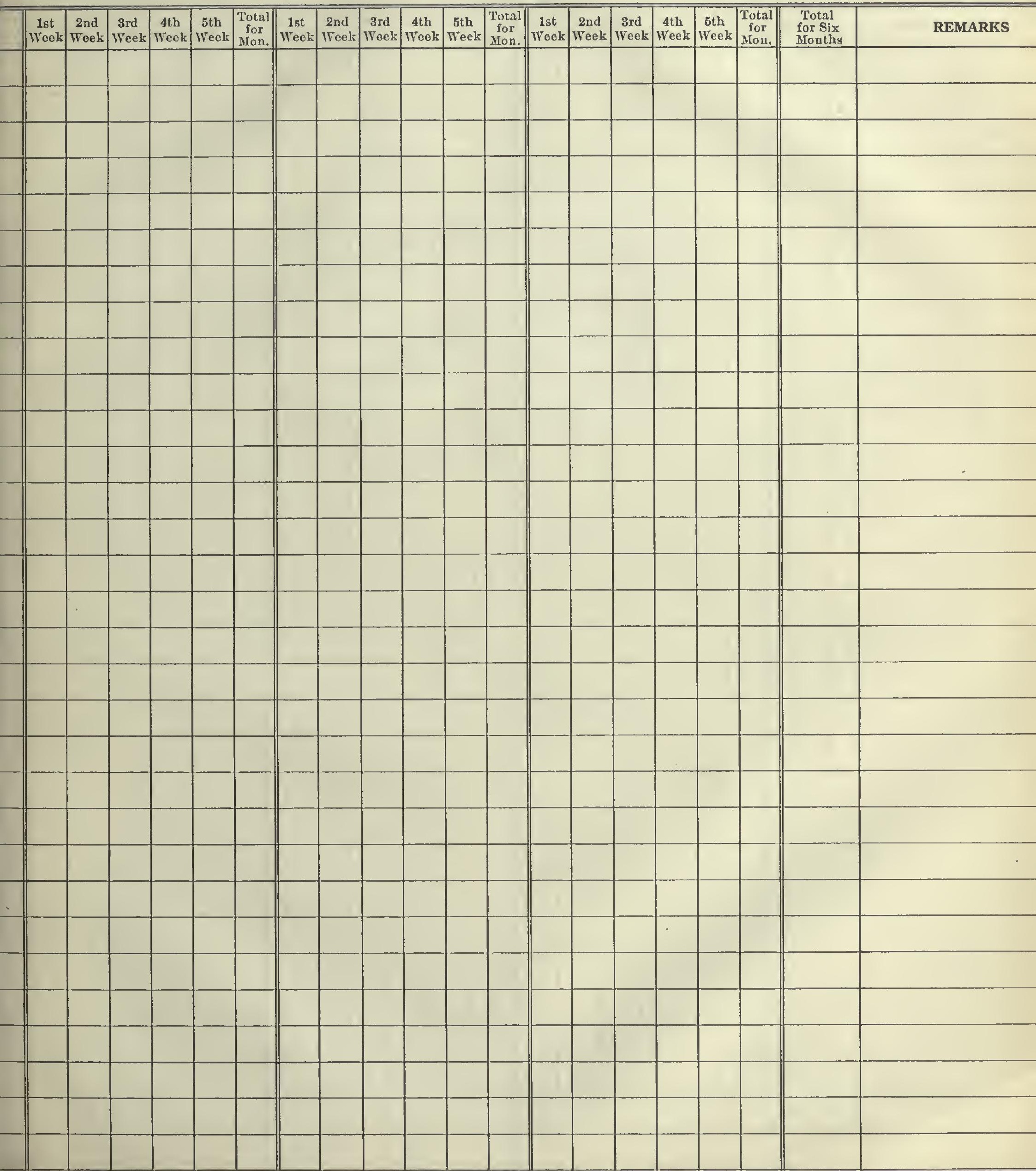




\section{INSTRUCTIONS FOR USE}

Daily Records of milkings morning and evening should be carefully kept on weekly cards, which may be purchased for the purpose; or records may be kept on any plain pad and entered at the end of each week.

$$
\text { Month of___ } 191 \text { ___ Month of___ Month of }
$$

\begin{tabular}{|c|c|c|c|c|c|c|c|c|c|c|c|c|c|c|c|c|c|c|}
\hline Cow No. & $\begin{array}{c}\text { 1st } \\
\text { Week }\end{array}$ & $\begin{array}{l}2 \mathrm{nd} \\
\text { Week }\end{array}$ & $\begin{array}{l}\text { 3rd } \\
\text { Week }\end{array}$ & $\begin{array}{c}\text { 4th } \\
\text { Week }\end{array}$ & $\begin{array}{c}\text { 5th } \\
\text { Week }\end{array}$ & \begin{tabular}{|c|} 
Total \\
for \\
Ilon. \\
\end{tabular} & $\mid \begin{array}{c}1 \text { st } \\
\text { Week }\end{array}$ & $\begin{array}{c}2 \text { 2nd } \\
\text { Week }\end{array}$ & $\begin{array}{c}\text { 3rd } \\
\text { Week }\end{array}$ & $\begin{array}{c}\text { 4th } \\
\text { Week }\end{array}$ & $\begin{array}{c}\text { 5th } \\
\text { Week }\end{array}$ & \begin{tabular}{|c|} 
Total \\
for \\
ylon \\
\end{tabular} & $\mid$\begin{tabular}{c|} 
1st \\
Wcekk
\end{tabular} & $\left|\begin{array}{c}2 \text { nd } \\
\text { Week }\end{array}\right|$ & $\left|\begin{array}{c}\text { 3rd } \\
\text { Week }\end{array}\right|$ & $\left|\begin{array}{c}\text { 4th } \\
\text { Week }\end{array}\right|$ & $\begin{array}{c}5 \text { th } \\
\text { Week }\end{array}$ & $\begin{array}{c}\text { Tot } \\
\text { fol } \\
\text { Ifor }\end{array}$ \\
\hline
\end{tabular}

1

2

4

6

7

8

0

10

11

12

13

14

15

16

17

18

10

20

21

22

23

24

25

20

27

28

20 
INSTRUCTIONS FOR USE

As all Months have 2 day or two over four weeks this record has been prepared with spaces for five weeks, the fifth space being intended for the record of the extra days in the month.

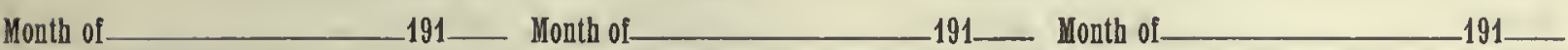

\begin{tabular}{|c|c|c|c|c|c|c|c|c|c|c|c|c|c|c|c|c|c|c|c|}
\hline $\begin{array}{c}\text { 1st } \\
\text { Week }\end{array}$ & $\begin{array}{c}\text { 2nd } \\
\text { Week } \\
\end{array}$ & $\begin{array}{c}\text { 3rd } \\
\text { Week }\end{array}$ & $\begin{array}{c}\text { 4th } \\
\text { Weok } \\
\end{array}$ & \begin{tabular}{|c|} 
5th \\
Week \\
\end{tabular} & \begin{tabular}{|c|} 
Total \\
for \\
Mion.
\end{tabular} & \begin{tabular}{||c}
1 st \\
Week \\
Wet
\end{tabular} & \begin{tabular}{|c|c}
$2 \mathrm{nd}$ \\
Week \\
\end{tabular} & $\begin{array}{c}\text { 3rd } \\
\text { Week } \\
\end{array}$ & \begin{tabular}{|c|} 
th \\
Week \\
\end{tabular} & \begin{tabular}{|c} 
5th \\
Week \\
\end{tabular} & \begin{tabular}{|c|}
$\begin{array}{c}\text { ototal } \\
\text { for } \\
\text { Ifon. }\end{array}$ \\
\end{tabular} & \begin{tabular}{|c} 
1st \\
Week \\
\end{tabular} & $=\begin{array}{c}2 \mathrm{nd} \\
\text { Week }\end{array}$ & $\begin{array}{c}\text { 3rd } \\
\text { Woek } \\
\end{array}$ & $\begin{array}{c}\text { 4th } \\
\text { Week }\end{array}$ & $\begin{array}{c}\text { 5th } \\
\text { Week } \\
\end{array}$ & \begin{tabular}{|c|} 
Total \\
for \\
Mou.
\end{tabular} & $\begin{array}{l}\text { Total } \\
\text { for Six } \\
\text { Months }\end{array}$ & REMARKS \\
\hline
\end{tabular}


Daily Records of milkings morning and evening should be carefully kept on weekly cards, which may be purchased for the purpose : or records may be kept on any plain pad and entered at the end of each week.

$$
\text { Mon'h of__ } 191 \text { _ Month of_______ Month of }
$$

NAME OF COW

\begin{tabular}{|c|c|c|c|c|c|c|c|c|c|c|c|c|c|c|c|c|c|c|}
\hline Cow ro. & \begin{tabular}{|c} 
1st \\
Week
\end{tabular} & $\begin{array}{c}\text { 2nd } \\
\text { Teek }\end{array}$ & $\begin{array}{c}3 \mathrm{rd} \\
\text { Week }\end{array}$ & $\begin{array}{c}\text { 4th } \\
\text { Treek }\end{array}$ & $\begin{array}{c}\text { 5th } \\
\text { Treek }\end{array}$ & $\begin{array}{c}\text { Total } \\
\text { for } \\
\text { Ion. }\end{array}$ & $\begin{array}{c}\text { 1st } \\
\text { Week }\end{array}$ & $\begin{array}{c}\text { 2nd } \\
\text { Week }\end{array}$ & $\begin{array}{c}3 \mathrm{rd} \\
\text { Week }\end{array}$ & $\begin{array}{c}\text { 4th } \\
\text { Week }\end{array}$ & $\begin{array}{c}\text { 5th } \\
\text { Week }\end{array}$ & 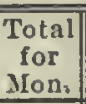 & $\begin{array}{c}\text { 1st } \\
\text { Weel }\end{array}$ & $\begin{array}{c}\text { 2nd } \\
\text { Week }\end{array}$ & $\begin{array}{c}3 \mathrm{rd} \\
\text { Week } \\
\end{array}$ & $\begin{array}{c}\text { 4th } \\
\text { W'eek }\end{array}$ & $\begin{array}{c}\text { 5th } \\
\text { Week } \\
\end{array}$ & $\begin{array}{l}\text { Total } \\
\text { for } \\
\text { Mon. }\end{array}$ \\
\hline 1 & & & & & & & & & & & & & & & & & & \\
\hline 2 & & & & & & & & & & & & & & & & & & \\
\hline 3 & & & & & & & & & & & & & & & & & & \\
\hline 4 & & & & & & & & & & & & & & & & & & \\
\hline 5 & & & & & & & & & & & & & & & & & & \\
\hline 6 & & & & & & & & & & & & & . & & & & & \\
\hline 7 & & & & & & & & & & & & & & & & & & \\
\hline 8 & & & & & & & & & & & & & & & & & & \\
\hline$\theta$ & & & & & & & & & & & & & & & & & & \\
\hline 10 & & & & & & & & & & & & & & & & & & \\
\hline 11 & & & & & & & & & & & & & & & & & & \\
\hline 12 & & & & & & & & & & & & & & & & & & \\
\hline 13 & & & & & & & & & & & & & & & & & & \\
\hline 14 & & & & & & & & & & & & & & & & & & \\
\hline 15 & & & & & & & & & & & & & & & & & & \\
\hline 16 & & & & . & & & & & & & & & & & & & & \\
\hline 17 & & & & & & & & & & & & & & & & & & \\
\hline 18 & & & & & & & & & & & & & & & & & & \\
\hline 19 & & & & & & & & & & & & & & & & & & \\
\hline 20 & & & & & & & & & & & & & & & & & & \\
\hline 21 & & & & & & & & & & & & & & & & & & \\
\hline 22 & & & & & & & & & & & & & & & & & & \\
\hline 23 & & & & & & & & & & & & & & & & & & \\
\hline 24 & & & & & & & & & & & & & & & & & & \\
\hline 25 & & & & & & & & & & & & & & & & & & \\
\hline 20 & & & & & & & & & & & & & & & & & & \\
\hline 27 & & & & & & & & & & & & & & & & & & \\
\hline 28 & & & & & & & & & & & & & & & & & & \\
\hline 20 & & & & & & & & & & & & & & & & & & \\
\hline 30 & & & & & & & & & & & & & & & & & & \\
\hline 31 & & & & & & & & & & & & & & & & & & \\
\hline
\end{tabular}


As all Months have a day or two over four weeks this record has been prepared with spaces for five weeks, the fifth space being intended for the record of the extra days in the month.

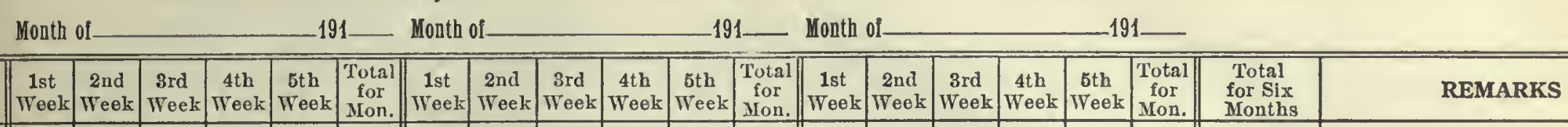


Daily Records of milkings morning and evening should be carefully kept on weekly cards, which may be purchased for the purpose; or records may be kept on any plain pad and entered at the end of each week.

Month of _ 191_ Month of

191_ Month of

NAME OF COW

\begin{tabular}{|c|c|c|c|c|c|c|c|c|c|c|c|c|c|c|c|c|c|c|}
\hline Cow so. & $\begin{array}{c}1 \mathrm{st} \\
\text { Week }\end{array}$ & $\begin{array}{c}2 n d \\
\text { Week }\end{array}$ & $\begin{array}{c}\text { 3rd } \\
\text { Week } \\
\end{array}$ & \begin{tabular}{|c|} 
4th \\
W'eek \\
\end{tabular} & $\begin{array}{c}5 \text { th } \\
\text { Week } \\
\end{array}$ & \begin{tabular}{|l||} 
Total| \\
for \\
Mon.
\end{tabular} & $\begin{array}{c}\text { 1st } \\
\text { Week }\end{array}$ & $\begin{array}{c}2 \text { nd } \\
\text { Week }\end{array}$ & $\begin{array}{c}\text { 3rd } \\
\text { Teek }\end{array}$ & $\begin{array}{c}\text { 4th } \\
\text { Week }\end{array}$ & $\begin{array}{c}5 \text { th } \\
\text { Week } \\
\end{array}$ & \begin{tabular}{|l|l|} 
Total \\
for \\
Xlon \\
\end{tabular} & $\begin{array}{c}\text { 1st } \\
\text { INeek } \\
\end{array}$ & $\begin{array}{c}\text { 2nd } \\
\text { Week } \\
\end{array}$ & $\begin{array}{c}\text { 3rd } \\
\text { Week } \\
\end{array}$ & \begin{tabular}{|c|} 
4th \\
Week \\
\end{tabular} & $\begin{array}{c}\text { 5th } \\
\text { W'eek } \\
\end{array}$ & \begin{tabular}{|l|} 
Total \\
for \\
Mon. \\
\end{tabular} \\
\hline 1 & & & & & & & & & & & & & & & & & & \\
\hline 2 & & & & & & & & & & & & & & & & & & \\
\hline 3 & & & & & & & & & & & & & & & & & & \\
\hline 4 & & & & & & & & & & & & & & & & & & \\
\hline 5 & & & & & & & & & & & & & & & & & & \\
\hline 6 & & & & & & & & & & & & & & & & & & \\
\hline 7 & & & & & & & & & & & & & & & & & & \\
\hline 8 & & & & & & & & & & & & & & & & & & \\
\hline 8 & & & & & & & & & & & & & & & & & & \\
\hline 10 & & & & & & & & & & & & & & & & & & \\
\hline 11 & & & & & & & & & & & & & & & & & & \\
\hline 12 & & & & & & & & & & & & & & & & & & \\
\hline 13 & & & & & & & & & & & & & & & & & & \\
\hline 14 & & & & & & & & & & & & & & & & & & \\
\hline 15 & & & & & & & & & & & & & & & & & & \\
\hline 10 & & & & & & & & & & & & & & & & & & \\
\hline 17 & & & & & & & & & & & & & & & & & & \\
\hline 18 & & & & & & & & & & & & & & & & & & \\
\hline 19 & & & - & & & & & & & & & & & & & & & \\
\hline 20 & & & & & & & & & & & & & & & & & & \\
\hline 21 & & & & & & & & & & & & & & & & & & \\
\hline 22 & & & & & & & & & & & & & & & & & & \\
\hline 23 & & & & & & & & & & & & & & & & & & \\
\hline 24 & & & & & & & & & & & & & & & & & & \\
\hline 25 & & & & & & & & & & & & & & & & & & \\
\hline 20 & & & & & & & & & & & & & & & & & & \\
\hline 27 & & & & & & & & & & & & & & & & & & \\
\hline 28 & & & & & & & & & & & & & & & & & & \\
\hline 20 & & & & & & & & & & & & & & & & & & \\
\hline 30 & & & & & & & & & & & & & & & & & & \\
\hline 31 & & & & & & & & & & & & & & & & & & \\
\hline
\end{tabular}


As all Months have a day or two over four weeks this record has been prepared with spaces for five weeks, the fifth space being intended for the record of the extra days in the month.

\begin{tabular}{|c|c|c|c|c|c|c|c|c|c|c|c|c|c|c|c|c|c|c|c|}
\hline $\begin{array}{c}\text { 1st } \\
\text { Week }\end{array}$ & $\begin{array}{l}\text { 2nd } \\
\text { Week }\end{array}$ & $\begin{array}{l}\text { 3rd } \\
\text { Week }\end{array}$ & \begin{tabular}{|c} 
4th \\
Week
\end{tabular} & $\begin{array}{l}\text { 5th } \\
\text { Week }\end{array}$ & $\left|\begin{array}{c}\text { Total } \\
\text { for } \\
\text { Mon. }\end{array}\right|$ & $\left|\begin{array}{c}1 \text { st } \\
\text { Week }\end{array}\right|$ & $\begin{array}{l}\text { 2nd } \\
\text { Week }\end{array}$ & $\begin{array}{c}\text { 3rd } \\
\text { Week }\end{array}$ & $\begin{array}{l}\text { 4th } \\
\text { Week }\end{array}$ & $\begin{array}{l}\text { 5th } \\
\text { Week }\end{array}$ & \begin{tabular}{|c|} 
Total \\
for \\
Mon.
\end{tabular} & $\mid \begin{array}{c}\text { 1st } \\
\text { Week }\end{array}$ & \begin{tabular}{|l} 
2nd \\
Week
\end{tabular} & $\left|\begin{array}{c}3 \mathrm{rd} \\
\text { Week }\end{array}\right|$ & \begin{tabular}{|} 
4th \\
Week
\end{tabular} & $\begin{array}{l}\text { Bth } \\
\text { Week }\end{array}$ & \begin{tabular}{c|} 
Total \\
for \\
Mon.
\end{tabular} & $\begin{array}{l}\text { Total } \\
\text { for Six } \\
\text { Months }\end{array}$ & REMARKS \\
\hline
\end{tabular}




\section{INVENTORY.}

$\begin{array}{ll}\text { Date When } & \text { Date One } \\ \text { First Taken } & \text { Year Later }\end{array}$

Name of Property

Value of land at market price

Talue of standing timber (stumpage worth) Talue of buildings at cost to build, less depreciation

Value of farm machinery, at cost less depreciation

Value of tools, harness, etc.

Value of household furniture, etc.

\section{Cash on hand and in bank}

Value of horses,(list them) at market price

Falue of cattle, (list them) at market price

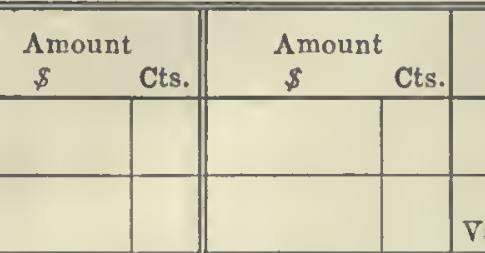

Name of Troperty

Amounts brought forward

Value of cattle, (continued)

Value of shecp, at market price. Number

Value of hogs, at market price. Number

Value of poultry, at markct price. Number

Value of hay, at cost. Tons

Value of oats, at cost. Bushels

Value of wheat, at cost. Bushels

Value of corn, at cost. Bushels

Valne of farm supplies, at cost

Value of household supplies, at cost

\section{Total value of your property}

To learn your exact worth add the total of all amounts owed you, (Seo next page)

Subtract the total of all amoints you owe. (See next pago)

This gives the amount of your net worth The gain in your net worth as sliown by cxcess of second inventory over the first is the profit of the year's bllsiness.

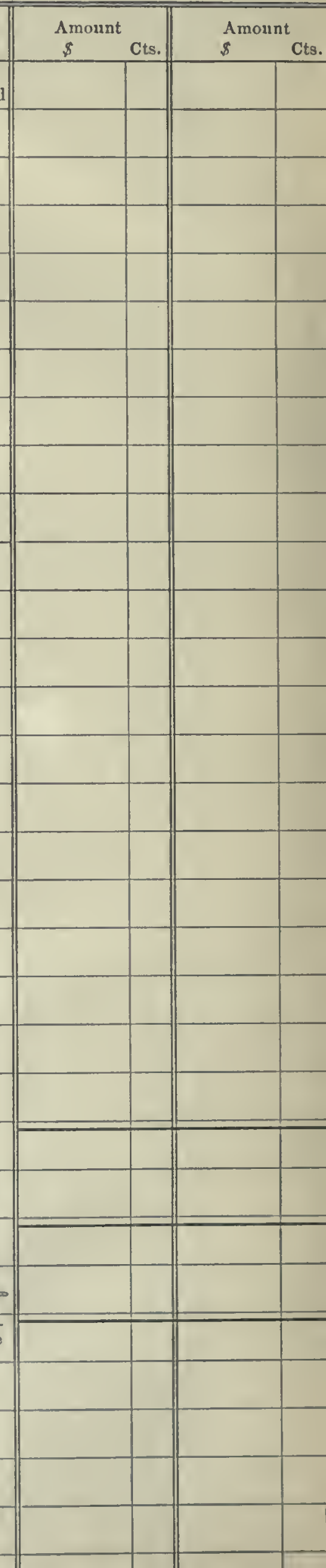


Date

First Taken

Date One

Amoun

$\$$ owed to you
ownts, Notes a

List of Accounts, Notes and Mortgages
Date When

First Taken
Date One

Year Later

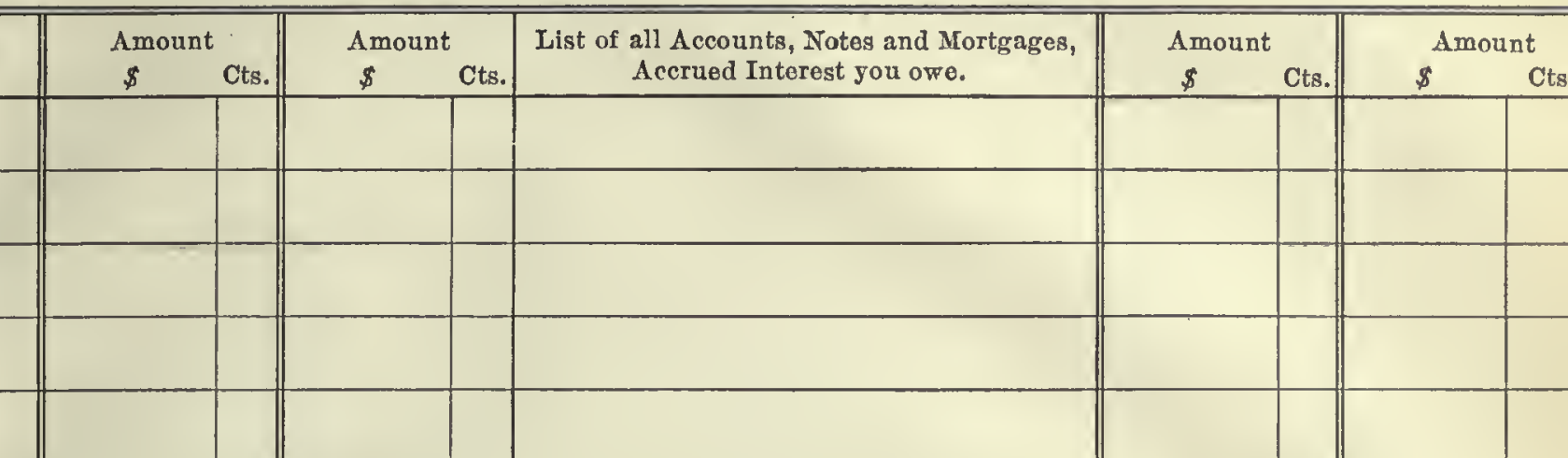


Bate

$19-\not 1$

19

$\mathscr{T}$

days after date, I promise to pay

$\mathscr{F}_{\text {ox }}$

ox order, the sum of

Dollars.

Talus received

Gate

$\mathscr{T}$

$\mathscr{F}$ ox

$\$$

Gate

$\mathscr{T}_{a}$

$\mathscr{F}_{0 x}$

$\$$

Pa to

$\mathscr{T}$

$\mathscr{F}_{0 x}$

$\$$
19

19

$\$$

days after date, I promise to pay y

ox orders, the sum of

Value received

Dollars.

19

days after date, I promise to pay

-on order, the sum of

Value received

Dollars.

19

days after date, I promise to pay on order, the sum of

Dollars.

Value received 

$\mathscr{T}_{0}$

-days aftex date, I promise to pay

$\mathscr{F}_{\text {ox }}$

ox oxders, the sum of

8

Yalue reccived

Dodlars.

DPate - '19- \$

19

$\mathscr{T}_{0}$

$\mathscr{F o x}$

8

Tahtur seceived

Dollaws.
19
19
en pay

\&

$19-\$$

Dollaws.
19
19
en pay

days aftex date, I promise to payy ox oxder, the sum of

days aftex date, Tpromise to payy
on oxder, the sum of

Dollars:

Value received

QPate $\quad \$$ 19

$\mathscr{T}_{0}$

$\mathscr{F}_{0 x}$ ox oxder, the sum of

days after date, I promise to pay Dollars. 

19

$\mathscr{T}$

$\mathscr{F}$ ox

Date

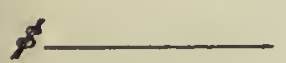

$\mathscr{T}$

Fox

Date

8

$\mathscr{T}$

Fox

Date

$\not$

$\mathscr{T}$

Fox

Date
Received from

Dollars.

fox

$f^{s}$

19

Received from

Dallas.

fox

$\not$

19

Received from

Dallas.

fox

$\$$

19

Received from

Dollars.

fore 

19

$\mathscr{T}$

$\mathscr{F}$ ox

Date

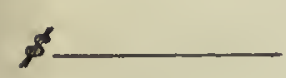

$\mathscr{T}$

Fox

Date

8

$\mathscr{T}$

$\mathscr{F}_{0 x}$

Date

8

$\mathscr{T}$

Fox

Dale
Received from

Dollars.

fox

$\psi^{\beta}$

19

Received from

Dollars.

fox

$\$$

19

Received from

Dallases.

fox

$\not$

19

Received from

Dollars.

fox 

19

$\mathscr{T}$

$\mathscr{F}_{\text {ox }}$

Date

8

$\mathscr{T}$

$\mathscr{F}_{\text {ox }}$

Date

8

$\mathscr{T}$

$\mathscr{F}_{\text {ox }}$

Date

s

$\mathscr{T}$

$\mathscr{F}_{\text {ox }}$

Date
Received from

Dollars.

fox

8

19

Received from

Dollars.

fox

$\$$

19

Received from

fox

$\$$

19

Received from

Dollars.

fox 

19

$\mathscr{T}$

$\mathscr{F}$ ox

Date

8

$\mathscr{T}$

Fox

Date

8

$\mathscr{T}$

$\mathscr{F}$ ox

Date

8

$\mathscr{T}$

Fox

Date
Received from

Dollars.

$f o x$

$\$$

19

Received from

fox

$\$$

19

Received from

Dollars.

fox

$\$$

19

Received from

Dollars.

fox 

19

$\mathscr{T}$

$\mathscr{F} a x$

Date

8

$\mathscr{T}$

$\mathscr{F}_{0 x}$

Date

8

$\mathscr{T}$

$\mathscr{F}$ ox

Date

8

$\mathscr{T}$

$\mathscr{F}$ ox
Received from

fox

$\&^{8}$

Received from

$\not 8$

Received from

$\$$

Received from

Date
19

for

19

fox

19

Dollars.

${ }_{100}$ Dollars.

Dollars.

${ }_{100}$ Dollars.

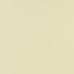

Dollars.

${ }_{100}$ Dollars.

.

Dollars.

$f a x$ 




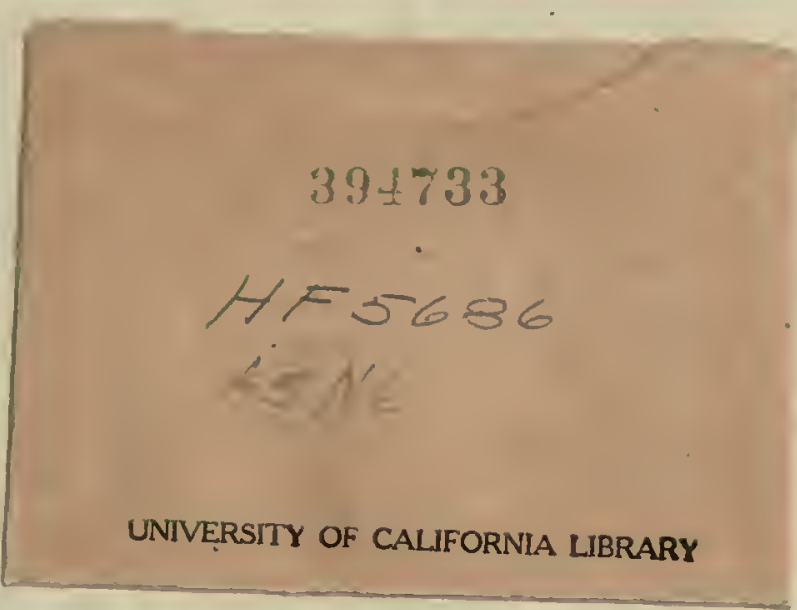


